5. I. LABRARYY 

$A-4$

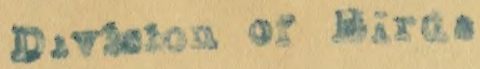






\section{Division of Birda}

\section{South Dakota \\ Geological and Natural History Survey}

Freeman Ward, State Geologist

\section{Bulletin 9}

\section{BIRDS}

OF

\section{SOUTH DAKOTA}

\section{MATHSONIAN INSTITUTION}

\section{พASHIUGTE* $2 \%$. D.C.}

By

William H. Over and

Graig S. Thoms

Series XXI

March 1921

No. 9

Bulletin

University of South Dakota

Entered as second-class matter, May 3, 1902, at the Post Office at Vermilion, South Dakota, under Act of July 16, 1894. 


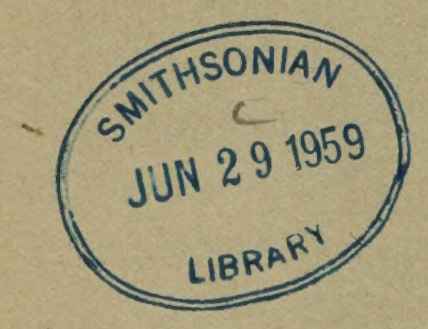




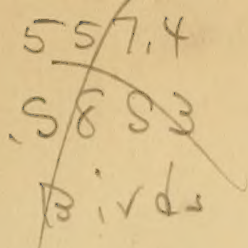





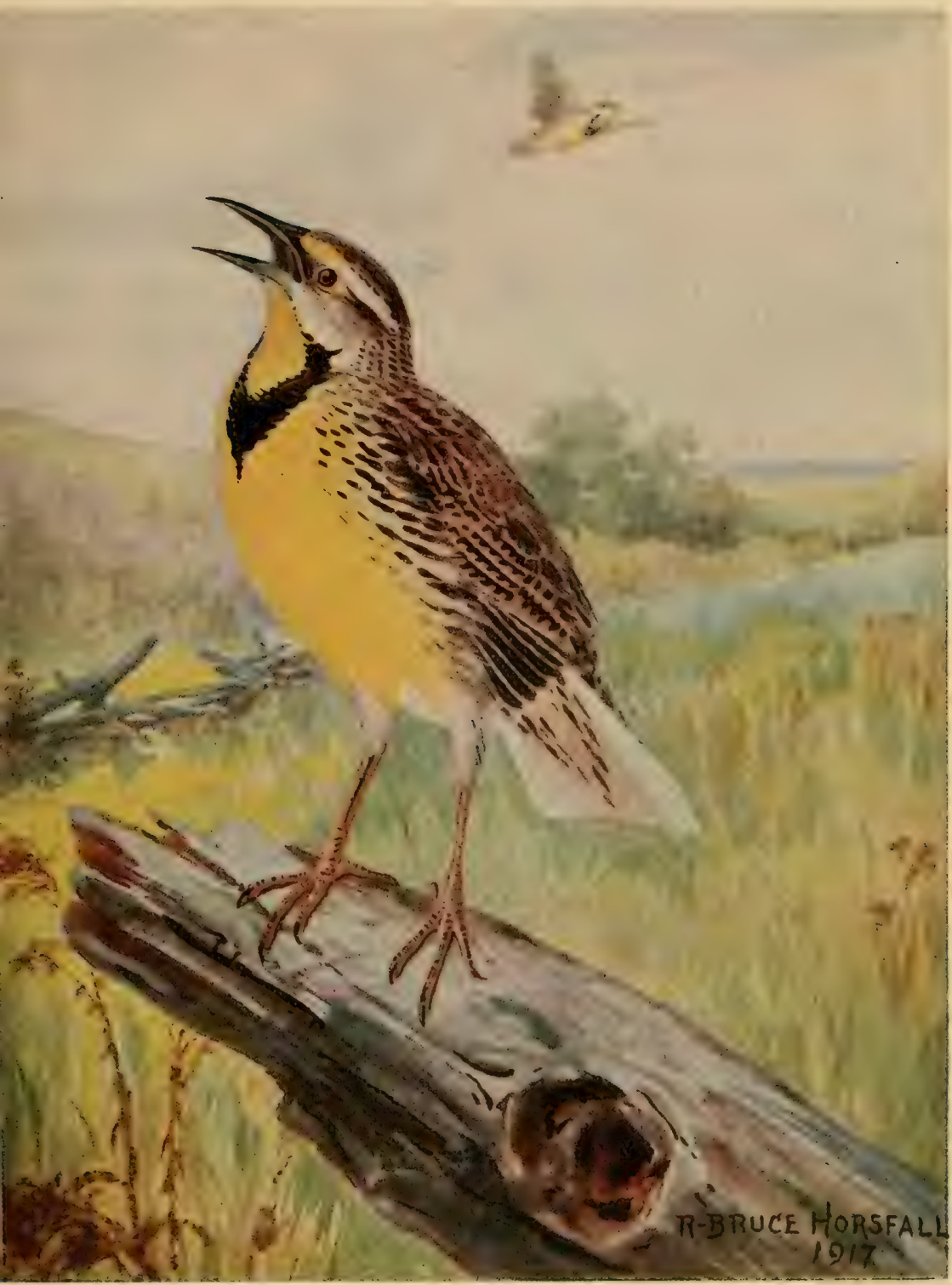

MEADOWLARK

Order-PASSERES

Family-ICTERIDE

Genus-Sturnella

Species-MAGNA

National Association of Audubon Societies 



\section{South Dakota}

Geological and Natural History Survey

Freeman Ward, State Geologist

\section{Bulletin 9}

\section{BIRDS}

OF

\section{SOUTH DAKOTA}

By

William H. Over and

Craig S. Thoms

Series XXI

March 1920

No. 9

\section{Bulletin}

\section{University of South Dakota}

Entered as second-class matter, May 3, 1902, at the Post Office at Vermillion, South, under Act of July 16, 1894. 



\section{PREFACE}

Effort has been made in this bulletin to obtain as complete a list of South Dakota birds as possible. In all, 322 species and subspecies have been recorded. With few exceptions these are represented in the University Museum collections at Vermillion.

There is perhaps no State in the Union where bird study is more perplexing than in South Dakota. From east to west the State embraces birds of woods, prairie and mountains. The range of many birds is constantly moving westward, and this causes variation in the migrating routes of many species. The Black Hills, lying only a little apart from the Rocky Mountains, are apt to be visited occasionally by western species.

From south to north, likewise, both trees and latitude affect the bird problem. The Missouri River with its wooded banks and ravines, traversing the middle of the State, provides conditions which attract some species farther north than they would otherwise come. But for this fact we probably would not have the beautiful Western Blue Grosbeak within our borders. Birds from farther east and south also, such as Cardinals and Wood Thrushes, follow the growing trees into South Dakota. Many birds are found in the southern part of the State which are never seen in the northern part; and some birds which formerly nested in South Dakota no longer do so.

So numerous, therefore, are the changes going on in bird life within the State that observations which were made a few years ago may not be accurate today and observations made today may not be accurate tomorrow.

The authors desire to acknowledge their indebtedness particularly to the late Dr. Elliott Coues and to Mr. Frank M. Chapman, with whose works their own observations have been diligently compared; and to $\mathrm{Mr}$. H. C. Oberholser and Mr. A. 
H. Howell of the United States Biological Survey, for determining species. Credit is given to other observers in the body of the text.

They desire also to acknowledge the kindness of various magazines in allowing the use of photographs previously used in illustrating articles by the authors.

The number with which the description of each bird begins is the one assigned to it by the American Ornithologist Union (third and last edition), and is convenient for reference to other works.

The authors have not attempted to give full descriptions of the birds but only so much as seemed necessary for identification. For more complete descriptions they refer the observer to the principal works mentioned in the attached bibliography. 


\section{CONTENTS}

Plate of Western Meadowlark............... Frontispiece

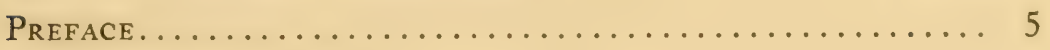

List of Illustrations . . . . . . . . . . . . . . 8

Regents of Education ..................... 10

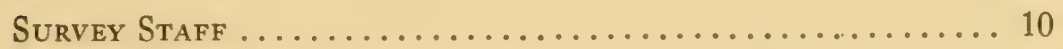

Letter of Transmittal..................... 11

\section{PART I}

The Importance of Bird Study................ 14

Bird Houses ......................... 17

The Bird Bath.............................. 19

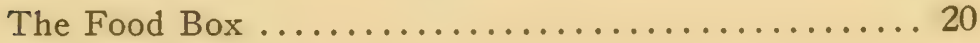

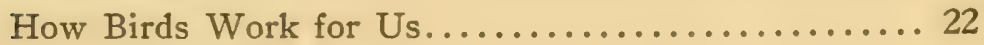

Bird Enemies ........................... 24

Protective Coloration .................... 28

Changes of Plumage................... 32

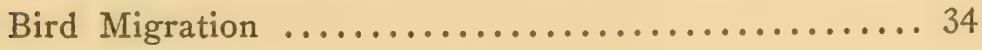

PART II

List and Description of Birds of South Dakota........ 43

PART III

Bibliography 


\section{LIST OF ILLUSTRATIONS}

Facing

Page

Male Bluebird at Nest...................... 14

A Well Made Wren House Covered With Bark.......... 18

A Rough Box Used for a Wren's Nest.............. 18

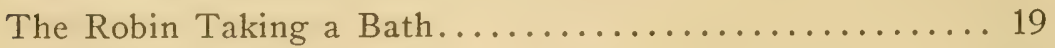

Rose-brested Grosbeak Taking a Drink............. 19

Hairy Woodpecker at Window Sill Food Box.......... 21

Downy Woodpecker at Food Box.................... 21

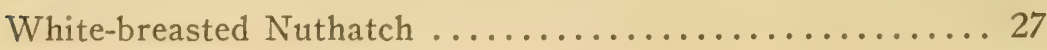

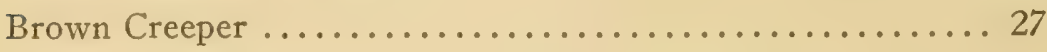

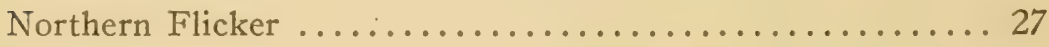

Chickadee ...................................27

A Chewink's Nest with Two Enemy Cowbird's Eggs...... 39

A Yellow-breasted Chat's Nest with Five Enemy Cowbird's

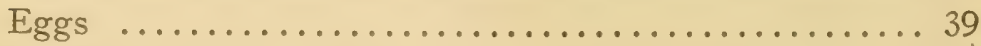

Black Terns in Migration.................... 48

Colony Nests of the Black-crowned Night Heron......... 48

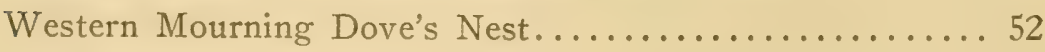

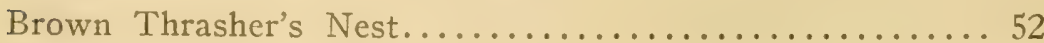

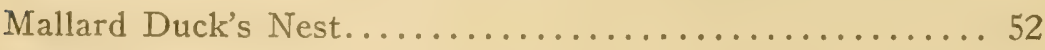

Marsh Hawk's Nest......................... 52

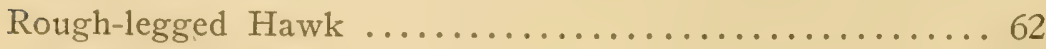

Red-shouldered Hawk ........................ 62

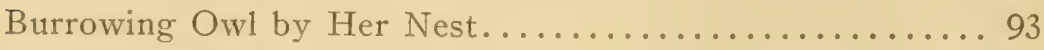

Kingbird Watching for Flies................... 93

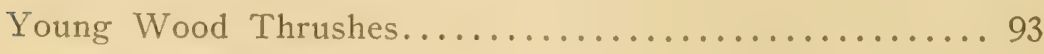

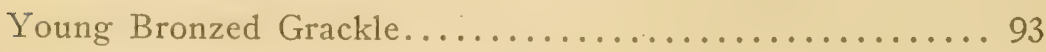

Blue Jay Watching for Insects...................... 95 
Catbird

Holes Made by Woodpeckers Drilling for Borers........ 95

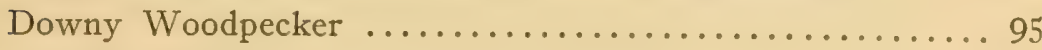

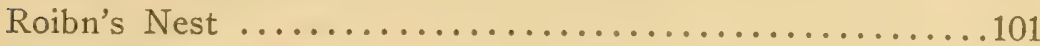

Two Female Baltimore Orioles at the Bath..............101

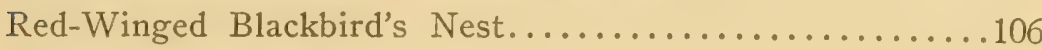

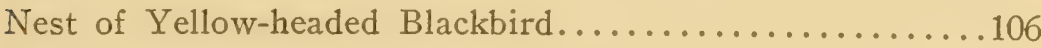

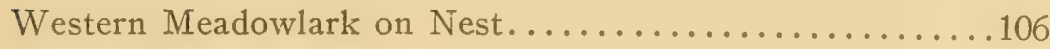

Western Meadowlark's Nest ..................... 106

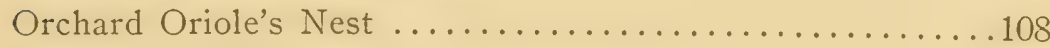

Baltimore Oriole's Nest .........................108

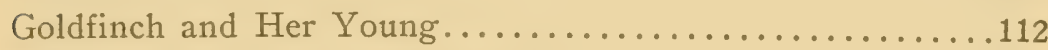

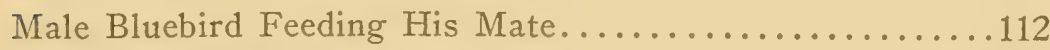

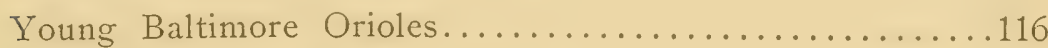

Young Rose-breasted Grosbeaks...................116

Nest of Bell's Vireo............................119

Blue Jay's Nest and Young............................ 119

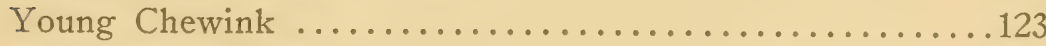

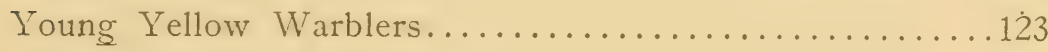

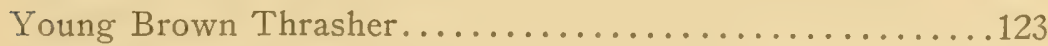

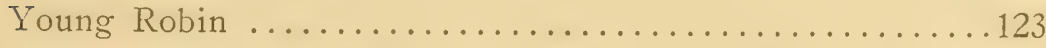

White-breasted Nuthatch at Food Box................127

Phoebe's Nest Under a Bridge...................... 127

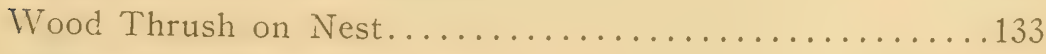

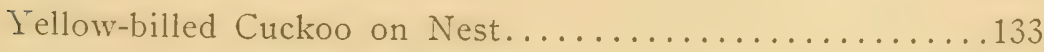




\section{REGENTS OF EDUCATION}

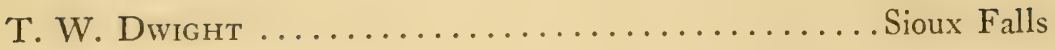

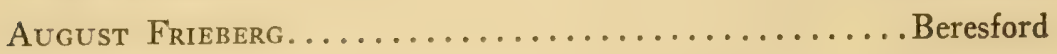

Frederick A. SPAFFord...............................

J. O. Johnson ...................... Watertown

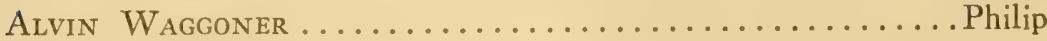

\section{OFFICERS}

T. W. Dwight, President........................... Falls August Frieberg, Vice-President ..................... Beresford Helen H. Gamble, Secretary.................... Frederick W. S. O'Brien, Treasurer ex-officio, State Treasurer.........Pierre

\section{SURVEY STAFF}

Freenian Ward, State Geologist.......Univ. of S. Dak., Vermillion Wrlliani Henry Over, Naturalist..... Univ. of S. Dak., Vermillion Walter Carl Toepelman, Geologist. .Univ. of S. Dak., Vermillion 


\section{LETTER OF TRANSMITTAL}

Vermillion, S. Dak. March 21, 1921.

Hon. T. W. Dwight, President, State Board of Regents.

Dear Sir:

To meet a very insistent demand for accurate information concerning the birds of the State the accompanying bulletin on the "Birds of South Dakota" has been prepared. I herewith submit this as Bulletin 9 of our Survey publications.

Mr. William $H$. Over, as a permanent member of our Survey staff, has been investigating and collecting birds all over the State for many years. Dr. Craig S. Thoms, Professor of Sociology at the University, has always been a keen observer and enthusiastic student of the feathered tribe. This joint authorship has resulted in a very fine product. I am sorry to say that lack of funds allowed by the Legislature for Survey work has limited the number and character of illustrations used.

Respectfully, FREEMAN WARD, State Geologist 



\section{PART I BIRD STUDY}




\section{THE IMPORTANCE OF BIRD STUDY}

The study of birds is of the utmost importance for every young person, for youth is full of superabounding energy, which must be expended in one direction or another. Any study that takes one to woods and fields is not only a source of interest but of health, and not only a present joy but also a delightful future memory. There are few experiences that we remember with greater pleasure in after years than our youthful field rambles with some friend or chum.

The study of either birds or flowers is an open door to Nature's secrets. It leads us into sympathetic companionship with every living thing, and this is a bubbling spring of interest, rest and joy. We weary of work and we tire of people, but whoever is intelligently sympathetic with Nature never tires of her companionship.

The writers always go on vacation in summer with a bird book, a flower book, a tree book, a field glass and a camera. On these trips they have met all sorts of people, some interested in every tree, bush, flower and bird, as well as in hunting and fishing. These interested people always have a good day whether or not game is taken or fish is caught. Others are dead to Nature; they know nothing of trees, bushes, flowers, or birds, and have no interest in them: they usually return disappointed and angry at night if fishing or hunting is poor.

It is of little use to go to woods and fields unless one sees and is alive to what one sees. Simply the rotation of the seasons is a delight to every nature student. The first Robin, Bluebird and Meadowlark are old friends come back again and he actually feels the joy of renewed companionship. When apples are in blossom he looks for the many-colored Warblers to fill the trees and is never disappointed; he counts the days until he shall hear the songs of Wood Thrush, Catbird and Oriole or, if he is on the prairie, of the Bobolink and Lark Bunting. $\mathrm{He}$ becomes the guardian and helper to Bluebirds and Wrens by providing them with nesting houses, and his bird bath brings under his observation all the different feathered folk in the neighborhood. He watches the two bird processions meet in 


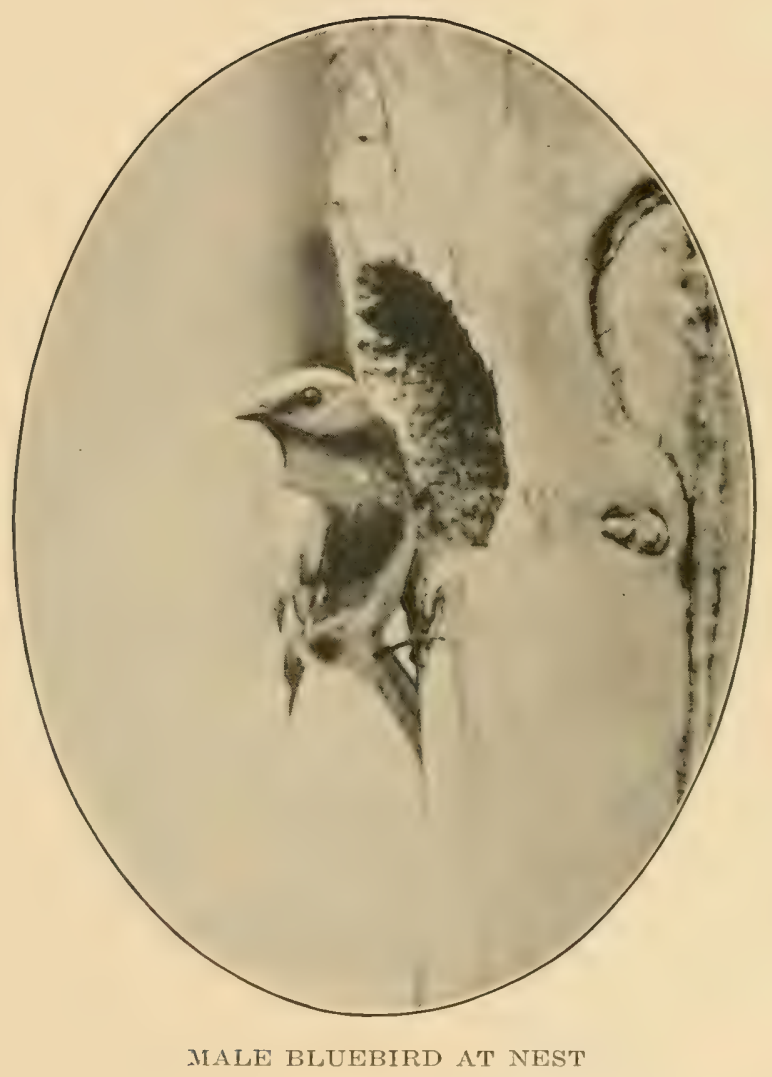



the arrival of the Robins and Bluebirds from the south and the departure of Nuthatches and Juncos for the north. He has fed birds all winter and knows every one of them by name. In a word, he is alive to the out-of-doors, in sympathy with a great sphere of life of surpassing daily interest.

One in beginning bird study is apt to become discouraged because there are so many. But this is as foolish as to refuse to make friends because there are so many people. Indeed, one learns birds just as he learns people: he is introduced to $\mathrm{Mr}$. and Mrs. Robin or Bluebird; his acquaintance with these leads to acquaintance with others. One of the delightful things about bird study is that it takes a lifetime and every new acquaintance is a new source of interest.

And yet bird study does not take much time either from work or other study. It is not a matter of time but of attention. One person walks along the street with his head down and his thoughts far away; another sees the Downy Woodpecker chiseling a worm out of a tree beside the walk or the Nuthatch standing head downwards on a tree trunk across the street. One person is wide awake and sees intelligently; the other is half asleep and oblivious to what goes on about him.

Two boys take a tramp together in the woods. Both enjoy the tramp but one has more than a tramp. He sees the Scarlet Tanager and hears the Wood Thrush sing; he flushes a Whip-poor-will and sees it light lengthwise on a limb; he hears the Flicker's call and knows why he is on the ground feeding on ants. He sees a bird that he does not know and hears a call that he does not recognize. New interests have thus come into his life. It was a tramp worth while.

The main thing in bird study is to get started. When we have once begun, it is a continuouts delight; it opens the eyes even wider to all nature about us, and in later life it becomes a source of restfulness from work and worry. It adds to every walk in the fields and to every tramp in the woods; it makes every racation on lake or in mountain tenfold enjoyable, for the best way to rest and enjoy is not to sit idle but to give ourselves to new interests. 
The initiative in bird study should be taken by school teachers. They are the natural leaders of the children in study, and pupils look to them for guidance. A little extra work here will amply repay any teacher by developing increased interest on the part of her scholars and will furnish a means of recreation and pleasure to them which she cannot measure.

One of the best ways to study is to form bird clubs, which should hold periodic meetings. This gives companionship in study, benefits each by the observations of all, and furnishes opportunity for correcting possible mistakes. Societies should be organized in winter and our few winter birds learned before the spring migrations begin. It is important to have a simple but good book, with colored plates, for purposes of identification. The authors know none better than the pocket edition of Chester A. Reed's "Bird Guide" for birds east of the Rocky Mountains, published by Doubleday, Page and Company, Garden City, New York. Farmers' Bulletin 513, entitled "Fifty Common Birds of Orchard and Prairie," gives splendid colored cuts of fifty common birds and especially emphasizes their economic value.

The University Museum at Vermillion is always glad to identify birds or nests to those sending in a description of them, and will answer inquiries about birds.

Every bird club may receive material help by getting in touch with the National Association of Audubon Societies, 1974 Broadway, New York City. Our county farm agents are always glad to render assistance in bird study, and none appreciates the value of birds more than they do. An effective organized relationship between our State Game Commission and all the active bird organizations of the State would be very helpful. Bird clubs should distribute literature on the subject, have their county papers publish short articles, and use every effort in carrying on an educational campaign to change public sentiment in favor of bird protection.

It is obvious that those interested in birds must show to the public that our birds are worth while, and one of the best ways to acquire lasting results is to carry on educational propaganda in the graded schools. All teachers should be urged to spend at least one hour a week in bird study with their students. 


\section{BIRD HOUSES}

Much can be done to attract summer birds about our homes by providing nesting places for them. Wrens, Bluebirds, Martins, and sometimes Chickadees, build in bird houses but each has individual taste in style and location of house.

Wrens are the least particular; they will build in anything from an old boot or tin can to a fine carpenter-made bungalow. The authors have known them to build in the tool box of a self-binder. They prefer a place with a small cavity, however, as it is their custom to fill completely the cavity with nest material. We really cannot place their house too near our own. They like it near the ceiling of the front or the back porch, where we are constantly passing, for although they scold us roundly for living in our own homes and for our impudence in encroaching on their preserves they really like to be near us and they feel safe in our presence. The entrance to the Wren's home should be the size of a twenty-five cent piece.

The Bluebird's house should not be large, for it does not build a bulky nest. The entrance must be the size of a fifty-cent piece. It loves to have its house placed in the open-along a fence, or even in the middle of a front or back lot, preferably in a line of bushes.

To secure a Chickadee's nest in one's yard is quite an achievement. They do not readily build in a house or in a made home of any kind that is not a part of a standing tree. Frequently they have been induced to build by excavations made in dead trunks. One nest was secured in the stump of a dead cherry tree by sawing half way through the trunk above and below where the nest was to be, carefully splitting off the front, making a gourd-shaped excavation, boring a hole in the top, and then nailing the face back on. Another was secured by cutting off a dead apple limb, excavating the center of the stump from the top, boring a hole in the side near the top, and then nailing on a round piece of board for a roof. The natural nesting place of these birds is in old Woodpecker's holes, and the nearer we simulate these the better the birds like it. 
Martins love a home in the open and elevated on a pole from ten to twenty feet. Their house may be at least two stories high and have many rooms, for they love to nest in colonies, and they return to the same place year after year.

A brushpile left in the corner of the yard will usually secure the nest of a Brown Thrasher or Catbird, and this means the best of bird music during the nesting season. A dead limb left on a tree, possibly with the top cut off, is likely to gain the nest of the Downy Woodpecker, Flicker, or Redhead.

It is well, as far as possible, to provide two nests for birds, as most of them rear a second brood. After their first young were grown Bluebirds have been known to go straight across the garden and take possession of a second house. 


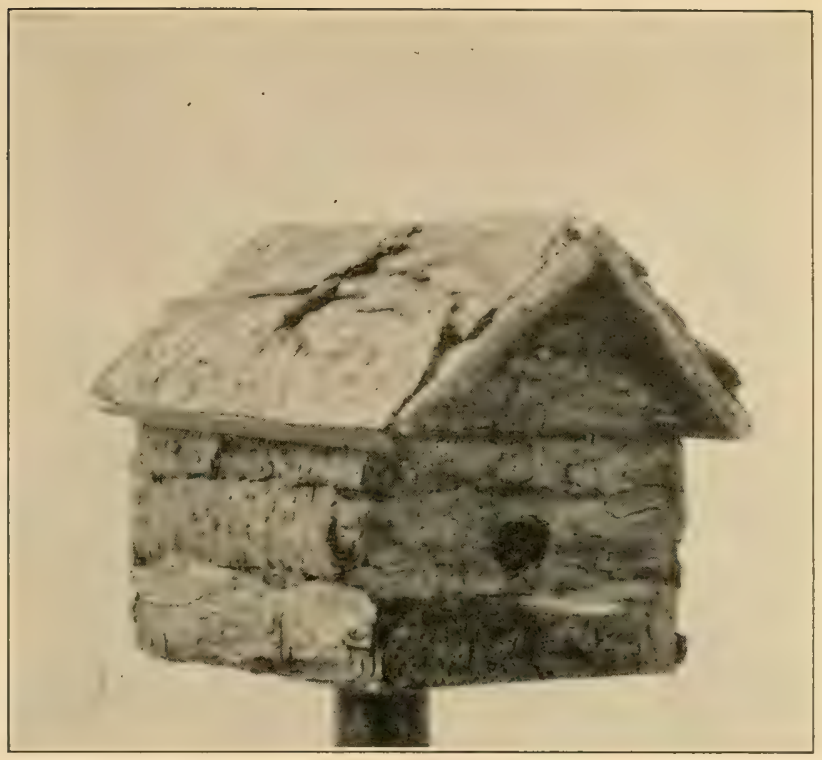

A WELL MADE WREN HOUSE COVERED WITH BARK

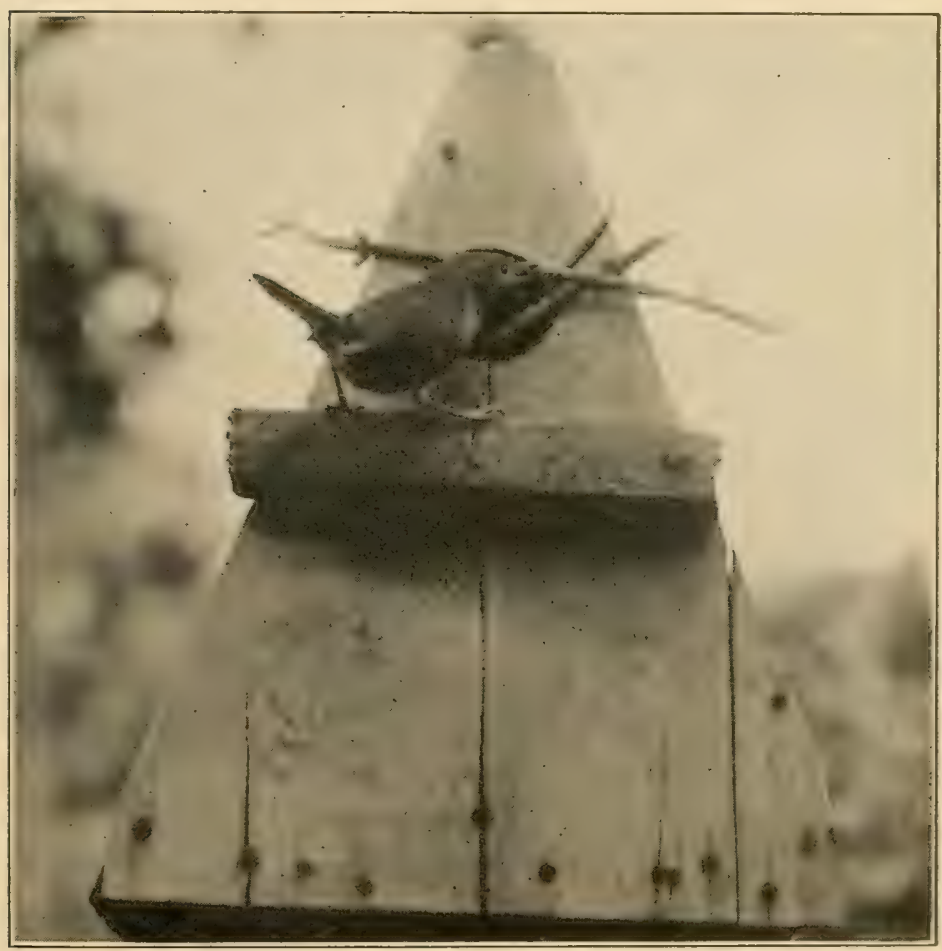

ROUGH BOX USED FOR A WWEN HOUSE 



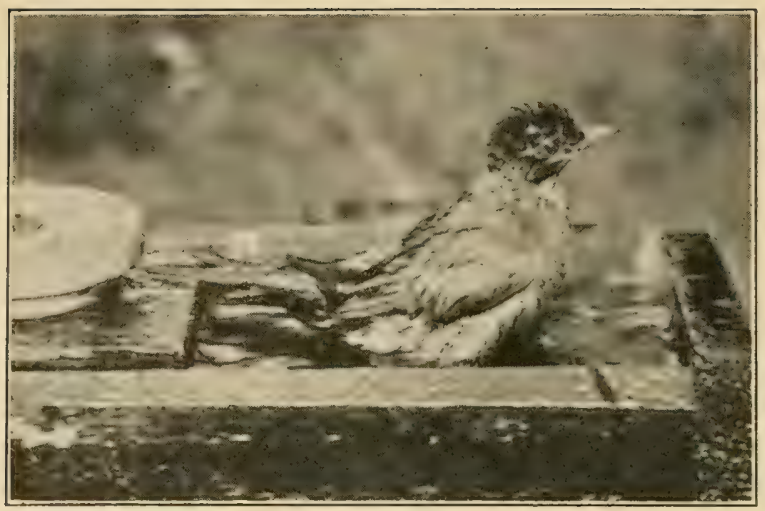

THE ROBIN TAKING A BATH

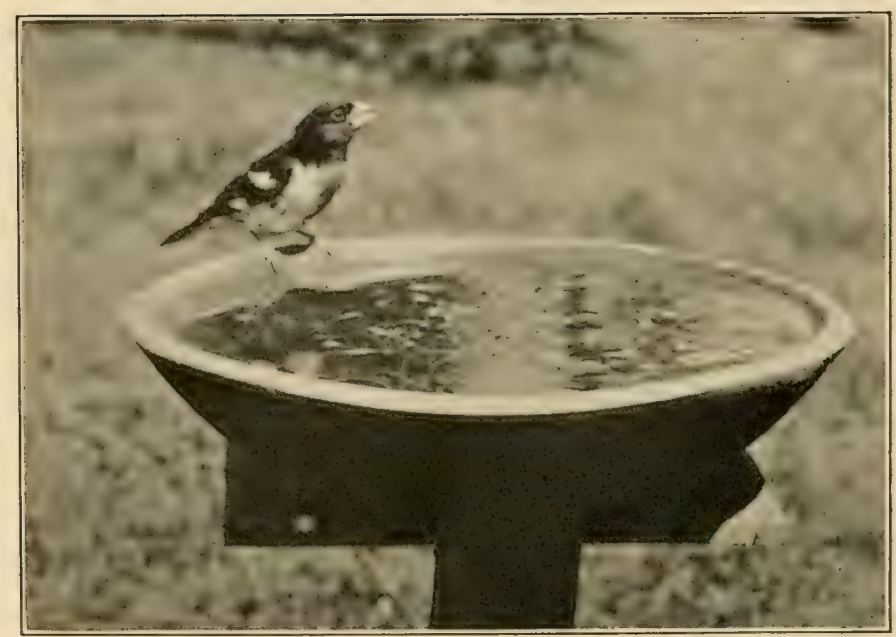

ROSE-BREASTED GROSBEAK TAKING A DRINK 


\section{THE BIRD BATH}

Nothing will do so much to bring different birds about the premises as a bird bath. This is especially important in South Dakota, for in most places it is a long way to open water. The bath should be contained in a wide, shallow dish, so that more than one bird can drink or bathe at a time. This is not necessary from the bird's standpoint, but it makes the bath much more interesting to watch. It also makes it much more instructive, as it gives ampler opportunity for birds to reveal their characteristics and their relations to one another.

If the bath will admit of it, it should be lined with sod, for in nature the favorite bathing place of birds is a grassy pool beside a running stream. Cut a piece of sod well under the roots, wash all the dirt out of it, shear the grass close, cover the floor of the bath with this sod rug, and then pour in water until it is an inch deep above it. The grass will grow in the water and should be cut regularly with the rest of the lawn.

The bath should be placed in the open and raised about two feet above the ground. Birds are off their guard to some extent when drinking and bathing, and the raising of the bath helps to protect them from prowling cats. 


\section{THE FOOD BOX}

Grosbeaks will come to a food box in summer for sunflower seeds, of which they are very fond, but in the bird world the food box is a winter institution. The attractive foods are suet, nuts and sunflower seeds. Chickadees and Nuthatches are especially fond of the seeds and nuts, while the Downy and the Hairy Woodpeckers are especially fond of suet. Grain of any kind should never be put in the box, as the birds mentioned do not care for it and the grain-eating English Sparrows will flock to it, driving all other birds away.

It is always desirable to have the box just outside the dining room window for then the family can watch the birds while sitting at table. With a well supplied box one will eat few meals in daylight during winter without enjoying the sight of bird neighbors feasting on his bounty.

To get birds to come to the box at one's window is a simple matter. The natural place for the birds mentioned to search for food in winter is on the trunks and larger branches of trees. There, in bark crevices, they find insects in their various forms of winter preservation. If the food box is first placed beside some tree the birds will soon find it. Then it may be moved by gradual stages to any desired place and the birds will follow.

The writer likes a box about two feet long and eight inches wide, with a standard about two feet high at each end, and these spanned by a crosspiece at the top. Nuts or sunflower seeds may be placed in the box and suet tied to the standards or crosspiece. This gives room for more than one bird to light at a time, and furnishes many exhibitions of bird ways in outwitting their fellows, at times even providing occasion for a passage at arms. Woodpeckers prefer to eat perched on the standards head upward and the Nuthatches head downward, while Chickadees are most at home on the box itself.

One should also have a storm food box, the sort that will let the birds in but keep the storm out. An ordinary box with one side open to the window will answer but it is much more 



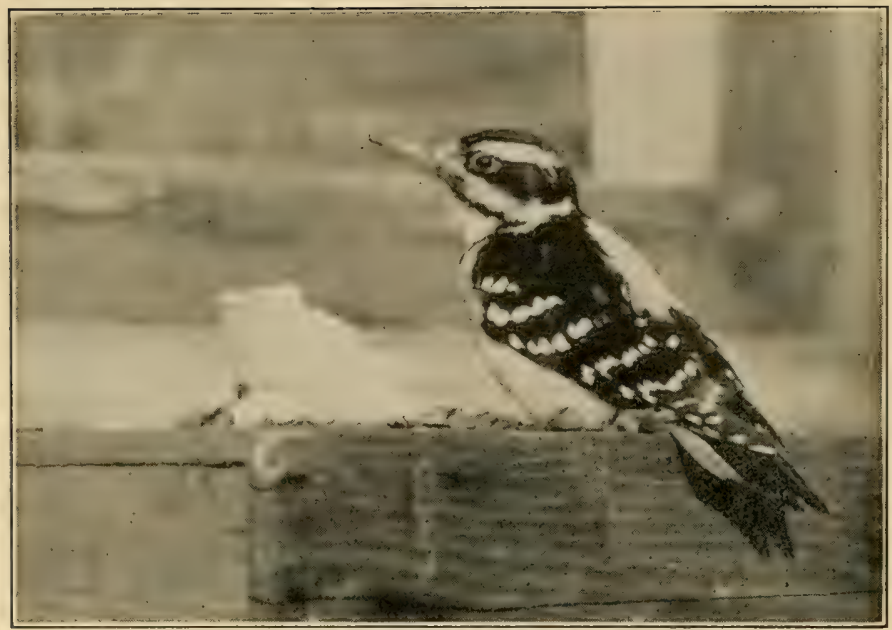

HAIRY WOODPHCKER AT WINDOW SILL FOOD BOX,

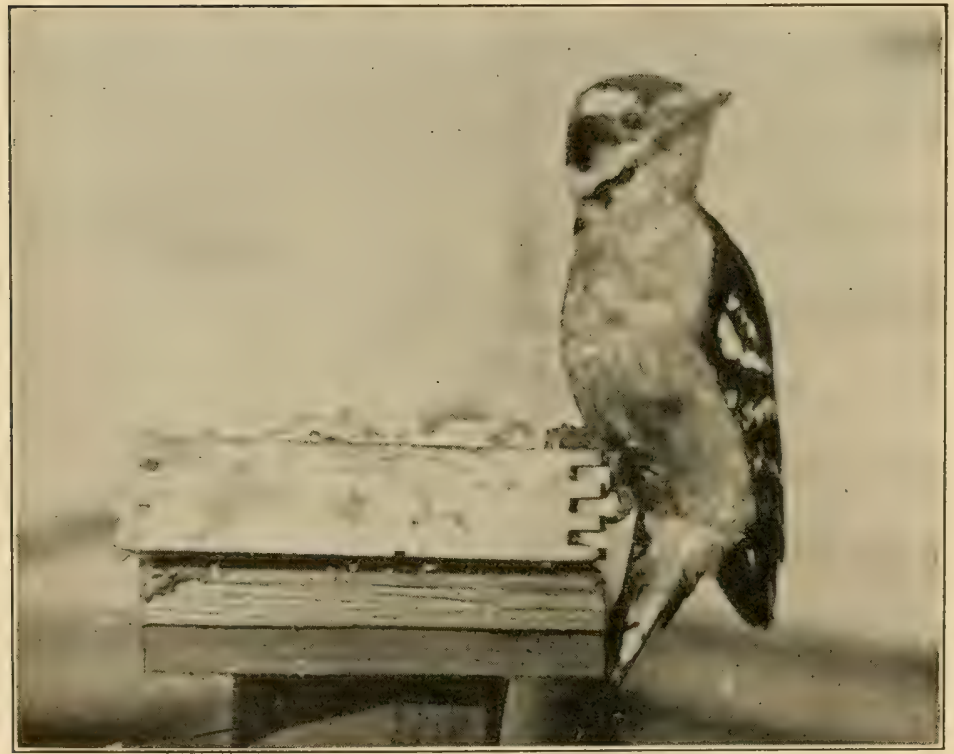

DOWNY WOODPECKER AT FOOD BOX 
interesting to exercise one's ingenuity in making a special box for the purpose and to notice what kind of box the birds like best.

The Brown Creeper is not apt to come to the food box except in excessively cold weather. But if one will place just outside of his window an old tree trunk in which he has bored a hole for the reception of suet this interesting bird will not be long in searching it out and will visit it repeatedly. 


\section{HOW BIRDS WORK FOR US}

To entice the birds about our homes and into our gardens by bird houses, baths and food boxes is not only to make them our friends but our servants. But for the birds there is no doubt that our vegetables, bushes and trees would be destroyed by insects. Most of our birds are insect eaters, and even seed-eating birds feed their young upon insects. All birds are hot-blooded creatures and require an enormous amount of food; and, too, they seem to be feeding from morning till night. In winter insects are in very condensed form, usually in the pupa stage, and it requires a great many to satisfy a hungry bird, so that every bird that searches our tree trunks in winter destroys what would be a vast multiplication of insects during the following summer.

The hosts of insects that the birds destroy in migration are beyond all computation, indeed beyond our imagining. Whole families of insect eaters, as they pass northward, appear in each locality just before or at blossom time-Flycatchers, Warblers, Vireos, Kinglets, Swallows and Swifts. They come just as most insects are emerging from the pupa state and just as others are hatching from the egg. Everywhere the trees are alive with hurrying, hungry, feeding birds. Their quick eyes search every leaf and examine every bud and blossom. They are the savers of our trees and bushes.

The larger birds that remain with us all summer, such as Bluebirds, Orioles, Thrushes, Thrashers, Catbirds, and scores of others, live largely on caterpillars. The favorite food of Cuckoos is the tent caterpillar, which is so destructive to orchards; and a few pairs of Grosbeaks in a potato patch will keep it free from the destructive potato bug. The little Wrens will creep under every vegetable in the garden looking for worms. Kingbirds use the clothesline as a perch and gobble up the passing flies, which carry disease from filthy places to infect our food. They also destroy robber flies, which kill and eat honey bees.

Every place in nature has its bird, and few are the birds which do not give good account of themselves in rendering service for the benefit of man. Even the Hawks and Owls, which most boys and hunters regard as legitimate prey, and shoot to let lie and rot, are among our most useful birds. There are 
three medium-sized Hawks that pursue and kill small birdsthe Goshawk, the Sharp-shinned Hawk and Cooper's Hawk. But these Hawks are not plentiful, and the damage they do is not great. The small and large Hawks, together with the Owls, are among the farmer's best helpers. When you see a large Hawk on hay or straw stack he is watching for mice; when you see him perched on a tree or telephone pole he is on the alert to destroy pocket gophers, which dig up the alfalfa fields; when you find him in the orchard or by the hedge row he is looking for rabbits, which girdle young fruit trees; and when you see him on wing leisurely searching meadow or marsh he is hunting field mice, pocket gophers, ground squirrels and other pests of the farmer. The little Sparrow Hawks, so abundant in our State, live on large insects and small mammals. The large Owls live chiefly on night-feeding mammals, such as mice, rats and rabbits. The little Screech Owl, whose night call is heard in practically every South Dakota town, is a great destroyer of mice.

While we are benefited most by the insect-eating birds, the seed-eaters render valuable service in destroying weed seeds. As nany as 9,200 weed seeds have been found in a single Mourning Dore's stomach. It has been estimated by the United States Department of Agriculture that in Iowa the Tree Sparrows alone, which only winter in the State, eat 875 tons of weed seeds annually, and that in the whole United States in 1910 the Sparrow family saved farm products to the value of $\$ \$ 9,260.000$.

The economic value of birds is no longer a matter of speculation or sentiment. It is based on careful investigation. The following data, for example, is taken from reports of the United States Department of Agriculture. The stomach of a Tree Sparrow held 40 chinch bugs and 10 other species: that of a Bank Swallow in Texas, 68 boll weevils; the stomachs of thirty-five Cliff Swallows, an average of 18 boll weevils each; those of two Pine Siskins in Colorado, 1,900 black olive scales and 300 plant lice; that of a Killdeer in Texas, over 300 mosquito larve; that of a Flicker, 28 white grubs; that of a Niyhthawk, $3+$ May beetles; that of another Nighthawh, 3.10 grasshoppers, 52 bugs, 3 beetles, 2 wasps and 1 spider; and that of a Duck, over 72,000 seeds. 


\section{BIRD ENEMIES}

There are more bird nests in the trees about our homes than in the outlying groves, and more birds in a well shaded town than in many times the same area of wild woods. The Robin places its nest in the tree nearest the walk; the Wren occupies a box under the porch roof; the Quail grows taner in spring and makes her nest in the old orchard.

Birds thus bring their families about our homes for protection from enemies, such as snakes, weasels, minks, skunks, foxes, coyotes, and other mammals. Crows, some Hawks and some Owls are also enemies. Some of these are not serious bird enemies, but, taken together, they make a formidable army, and the birds fly to us for protection.

The destruction of birds' nests by these enemies, together with wind and storms, is almost past belief. A careful observer says that during a whole season he has not known a single Wood Thrush's nest to succeed. In 1915 five Meadowlarks' nests were observed in a grassy corner of the University campus and only one succeeded. During a whole season his efforts to secure a photograph of young Kingbirds failed. Something invariably happened either to eggs or young. Probably not more than one out of five Yellow Warblers' nests succeeds. And even the strong, masterful Robin has been observed to "make good" only with his third nest.

English Sparrows are bird enemies in two ways: they are so numerous, curious and persistent that they flock to any spot where other birds are busy and make themselves a nuisance, so that other birds simply leave; they also rifle birds' nests. The writer has seen them get into a Robin's nest, throw the eggs to the ground, tear up the lining, and leave the egg-cradle a wreck.

There is perhaps no more destructive bird enemy than the Cowbird. It builds no nest of its own, but lays its spotted eggs in the nests of other birds, ustrally those that hold spotted eggs. The egg of this parasite has a smoky ground color spotted 
all over with darker and somewhat irregular spots. It looks like the sinister thing it is, lacking the clear ground color and definite spots of most eggs.

While the Cowbirds are generally seen in pastures feeding upon insects disturbed by cattle and horses as tiey graze, during nesting time the females are seen in groves and among bushes eyeing the movements of other birds and watching a chance to slip into their nests to lay their own eggs. The writer has found five eggs of this enemy in nne Yellow-breasted Chat's nest; three are not infrequently found, and two are quite common.

These parasitic eggs are destructive of the rightful young because they hatch more quickly than other eggs, and their young are rapid-growing, pot-bellied things. Owing to their rapid growth, size and strength they take most of the food brought to the nest and literally starve and crowd the parents' own young to death. The strange thing is that, with the exception of the Yellow Warbler, birds either do not know the danger of this egg or do not know how to defend their own young against it. Parent birds will even feed these foster children after they have left the nest. The Yellow Warbler discerns the danger and buries both these enemy eggs and her own by building a second nest above them.

Next to the Cowbird as a nest rifler should be placed the Blue Jay. He is an egg eater and will sometimes destroy young birds. When other birds are nesting it is the regular custom for Blue Jays to form in squads of three to six and make excursions from one grove to another, or from one part of a shaded town to another. These are nest robbing expeditions and are made with loud outcries, as though for the purpose of terrifying other birds. The writer one day watched three attacking a Robin's nest. The male Robin pursued the first intruder, the female the second, but there was no Robin to pursue the third. On this occasion, however, the male Robin returned in time and the pair succeeded in driving off the thieres, but the next day the nest was rifled.

The Crow is listed by writers among bird enemies, although the authors have never caught him in any nest robhing 
acts. Every observer, however, has seen Kingbirds and Blackbirds light between his hurrying wings and drive him precipitately from the vicinity of their nests, which is presumptive evidence against him; and his thieving propensities are well known.

Hawks and Owls as a rule do not make a business of killing young birds and, as far as the writer is aware, never molest birds' nests. Exceptions must be made of the three Hawks already mentioned-the Sharp-shinned, Goshawk and Cooper's Hawk. These three are swift fliers and kill and eat small birds whenever they can catch them, and of course are always eager to appropriate young birds either in the nest or out. Doubtless any Hawk or Owl will occasionally rifle a nest of young birds, but the Owls and the large and small Hawks do not seek their food in this way. Their food, as indicated elsewhere, consists principally of small mammals, and they make it their business to hunt for mammals and not for birds.

Snakes always seem to strike birds with terror, and for this there is good reason. These stealthy creatures are always on the watch for nests and young. They easily climb into high bushes and even ascend sloping trees. The writer was one day attracted by the combined cries of seemingly all the birds in the neighborhood-cries of fear, terror and distress. A snake had climbed into a high gooseberry bush which held a Catbird's nest, and was leisurely gulping down one of the half-grown young. All the birds were vainly endeavoring to drive him away, but he paid no attention. A bull snake rifled a Cheewink's nest which the writer was watching for photographic purposes, and made his own nest or burrow under it. He had driven a hole directly through the center of the nest. The young were destroyed but one unbroken egg was found in the loose dirt which the snake had worked up.

Many birds' nests are destroyed by wind and storm. The writer has known a Cuckoo's nest to be literally blown out of the tree; and every few years after a severe wind and rain storm both eggs and young birds are seen beside or on the walk between his home and the University in Vermillion. 


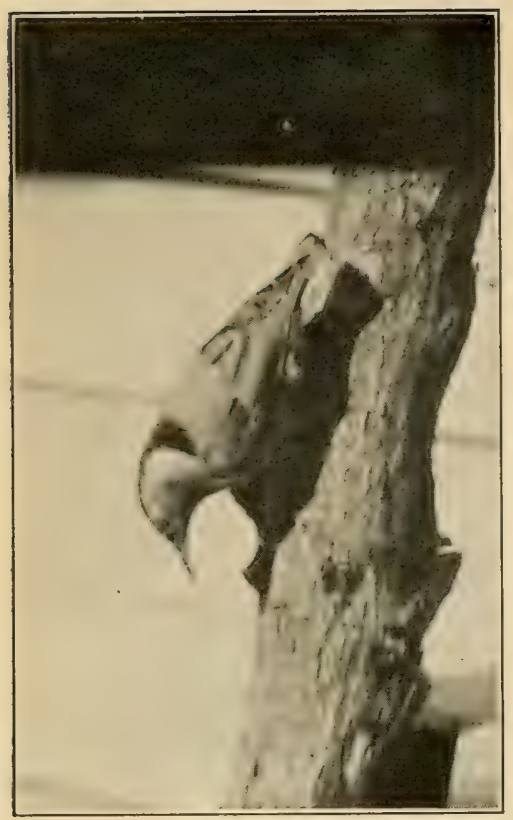

WHITE-BREASTED NUTHATCH

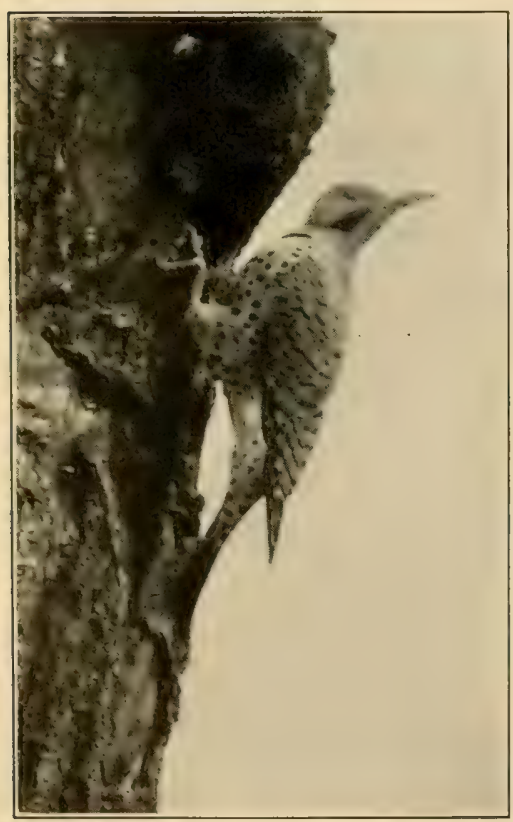

NORTHERN FLICKER

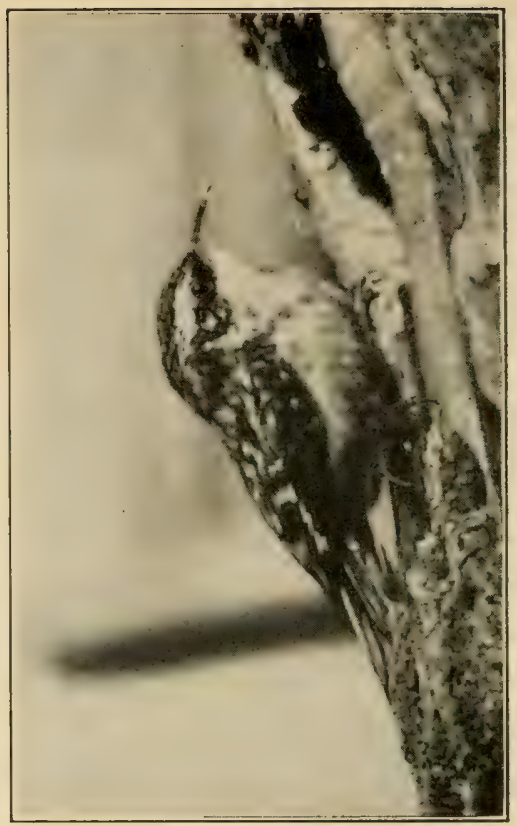

BROIVN CREEPER

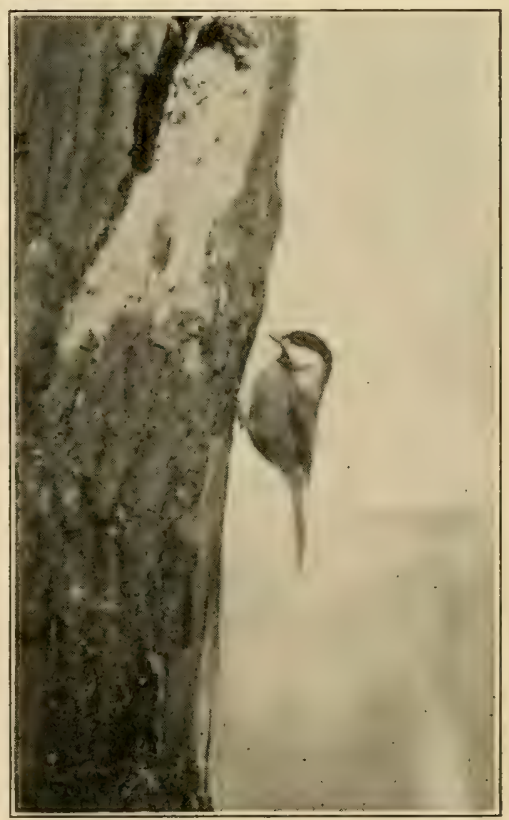

CHICKADEE 
The thoughtless bird photographer may be a bird encmy. In photographing birds, leaves and twigs should never be removed. They may be tied back to let light in for the picture, but should always be carefully replaced. When they are torn away the nest is almost sure to be rifled. Birds know how to place their nests so as to protect them best and when their instinctive plans are disarranged their treasures are endangered. Everything about a bird's nest should be left precisely as found. And even while photographing one should be careful not to allow direct sunlight to fall upon very young birds, as it is almost sure death to them.

Boys with air guns and other guns are sometimes bird enemies while not meaning to be such. The writer once came upon two fine boys of his acquaintance in an orchard shooting English Sparrows, as they thought. They were shooting Tree Sparrows that had just arrived from the north to spend the winter with us. Sparrows are difficult to tell apart, and when we shoot English Sparrows it is safest to shoot those near houses, so as to be sure that we are killing real bird enemies.

There is no greater enemy of birds than the household cat. Cats are natural hunters; they easily climb trees to get at the nests; and young birds upon the lawn are entirely at their mercy. It has been estimated that cats kill one half of all young Robins in Vermillion every summer.

The list of bird enemies is long and it is not a pleasant task to write about them. It is important for us to know a few of them, for the more we know of these enemies the better friends we will be to the birds, especially as they trust us and bring their nests to our very doors for protection. 


\section{PROTECTIVE COLORATION}

In studying birds one must ignore the females. This would be a rather unsafe policy in studying human beings, but among birds it is necessary because the males are the singers and wear the bright colors, while the females do not "shine" either in music or dress. One learns the females easily because they are the companions of the males during the mating season. But for this fact the study of female birds would be a very difficult task, for most of them have sober colors, and the females of many species resemble each other. For example, it is not easy to distinguish the females of several different Blackbirds, or of numerous Sparrows. Of course in some species males and females are alike, but bright colored males and sober colored females is the general rule.

The colors of male birds are"always the brightest in the mating season, as though for the purpose of being attractive to the females. Some have thought that the most attractive males won the females, and then, reproducing their kind, developed in the species increased attractiveness. Others have thought that beauty in males was connected with strength and virility, and that stronger males won the females because of their prowess in driving off other stitors.

It is difficult to decide such matters, but it seems certain that in the modest colors of females nature has made careful provision for the protection of the mother on her nest. The dappled brownish black of female Red-winged and Yellowheaded Blackbirds blends perfectly with the varying light and shade that play over their nests from the tops of flags and rushes swaying above them.

The female Rose-breasted Grosbeak is about the color of the materials of which she builds her nest, and the colors of both herself and her nest are not unlike the color of bark. The male Scarlet Tanager is like a burst of flame in the forest, but his mate has the color of green leaves, and when on her nest can scarcely be seen.

Birds of prowess, like Blue Jays, Crows and Hawks, show little difference in color between males and females. 
They are able to defend themselves. Birds that make their nests in cavities, like Woodpeckers, Kingfishers, Bluebirds and some Swallows, show little difference in color between the sexes, and in several of these cases the females are highly colored.

While there are many exceptions, birds are generally colored like their surroundings. The whole Vireo family, for example, is olive green or greenish gray, and these birds are scarcely noticed as they flit through the trees and gather food from the leaves. The large Warbler family migrates northward in blossom time, when the splashes of yellow and white in their bluish gray plumage seem simply to add so many more blossoms as they flit through the trees. When they return in the autumn the blossoms have disappeared and their bright spots have been greatly obscured.

Prairie Chickens and Grouse can scarcely be seen in upland grass or stubble field. The Ruffed Grouse, both by coloration and rigid attitude, looks like the stump beside which he stands. Woodcocks and Quail are the color of the dry leaves in which they hide. All Snipes are the color of dried grass beside which or in which they run. The American Bittern can with difficulty be distinguished from the cat-tail beside which he stands; and the Great Blue Heron is almost indistinguishable when viewed against the rushes.

The study of coloration in birds' eggs is very interesting and very perplexing. In the wild there would seem to be a relation between the color of a hird's egg and the color of the bird that lays it. Among barnyard Chickens it is not so. All hens lay white eggs whether they themselves are white, buff, dappled gray or black. And yet, as we know, some hen's eggs are whiter than others.

But a Crow lays just such an egg as you would expect a Crow to lay-a smoky, darkly blotched egg. The Cowbird has an egg of similar character. All Blackbirds' eggs have a dusky ground color and are variously spotted and splashed with black. The Orioles, which are are brighter colored Starlings, have lighter colored eggs, which are not so heavily spotted and 
splashed; while the Meadowlark, our lighter colored Starling, has an ideal egg, with clear ground color and exquisite brown spots.

This line of reasoning cannot be followed far, however, without becoming inextricably tangled with the problem of protective coloration; for example, the eggs of the Catbird, Robin and Wood Thrush, while varying in shade, are greenish blue, while the birds themselves are very differently colored.

Notwithstanding exceptions, there would seem to be a good deal of protective coloration in the shading and spotting of eggs. The greenish blue eggs just mentioned are difficult to see in the shade of trees and bushes where the nests are placed. All eggs that are spotted and splashed are protected thereby in the dappled lights and shadows that play over them when uncovered in the nest. Most birds that nest inside of holes, such as Woodpeckers, have white eggs; but exceptions at once occur in the exquisite brown egg of the Wren and the delicate blue egg of the Bluebird. It will be noticed that these fall under the other rule, that of the color of the birds themselves.

The Mourning Dove's pure white eggs, laid on a slender scaffolding of roots and exposed to the sight of every nest robber in the woods, are a glaring exception to color protection; and the exception is more marked when we remember that the Dove offers no defense of its eggs, except to flutter away as though wounded to lure the intruder from its treasures. The Mourning Dove's nest is probably rifled more than any other nest in the woods, but this is compensated for by the fact that the Dove breeds almost continuously throughout the season. They have been found brooding eggs in September.

Most Hawks' eggs are white or cream color, sometimes with spots, but they are able to defend them.

Some colors are not only for defense but also for offense. Owls are noted for protective coloration, doubtless not so much for their own defense as to allow them to approach their prey unobserved. The Snowy Owl changes color with the seasons, becoming nearly white when the ground is covered with snow. 
Perhaps the most remarkable example of adaptive coloration in the bird world is found among the Ptarmigans or Snow Grouse, which, although having the Grouse colors in summer, turn pure white in winter. Mr. Frank M. Chapman calls attention to the fact that Snowy Owls feed on Ptarmigans. It would appear, therefore, that the Ptarmigan's colors mean concealment for defense, while the Owl's mean concealment for approach and attack. The soft, quiet flight of Owls also assists them in coming upon their quarry unobserved.

The same relation would seem to exist between whole classes of birds, for example, Hawks and Grouse. Both are modestly colored, the Grouse evidently for concealment and Hawks for attack. All Flycatchers also have modest colors. They can hardly be seen as they perch upon dead branches and doubtless this gives them advantage in darting out upon passing insects.

It should be noted that all birds are lightest colored on their under parts, many of them white. This is an important element in protective coloring, since the under parts are aiways in shadow. They must therefore be lighter in order to make the color effect uniform.

The whole matter of color protection is filled with difficult questions, owing to the many exceptions, but it is a subject of intense interest for study, and one that comes under almost daily observation if our eyes are open to observe the facts. 


\section{CHANGES OF PLUMAGE}

The changes of plumage observed in Ptarmigans and Snowy Owls are evidently cases of adaptive coloration; but there are other cases where such adaptation is not so evident.

The male Goldfinch is bright yellow with black cap, wings and tail in summer, but in winter he is scarcely distinguishable from his mate. Many think these birds migrate south in autumn, whereas they are annual residents. They are little noticed in winter because males, females and young all look practically alike. Is this protective coloration? It is true, of course, that the male's bright yellow summer dress would make him a marked object in the bare winter landscape, whereas the unobtrusive, sparrow-like plumage of the females and young permits these birds to feed by the half dozen on sunflowers and weeds in winter almost unobserved.

If the above suggestion regarding protective coloration be correct, several other birds must be put in the same class. Before the Bobolinks go south the males have lost their glowing white, buff and black and have taken the colors of the females and young. They may be seen in late summer gathered in small flocks perched on wire fences that run through meadows. They are scarcely recognized as Bobolinks. The song is gone; the wedding dress of the male has faded away; they are now prepared for the southern journey, and are all dressed in "khaki," so as to be as little observed as possible by enemies.

The flaming coat of the male Scarlet Tanager disappears in autumn and, although his wings and tail remain black, his body takes on the olive green of the female.

These seasonal color changes are not very well understood. Of course, all birds molt their entire plumage after the nesting season; some molt their whole plumage again in the spring; others molt their body feathers in spring; while some do not molt even all their body feathers. Changes which come by molting are easily understood, but the above changes do not always come by molting. Some have thought that the feathers change their pigment; others that the tips of the feathers, which 
are sometimes differently colored, break up and fall away or are worn off.

The writer has seen male Goldfinches in spring with the yellow showing clearly under the brownish tips of the winter plumage. These brownish tips in some way disappeared, leaving the bodies of the birds pure yellow.

The colors of birds, as before indicated, are always highest in the mating season. Redwing's epaulets fairly blaze; Yellowhead's neck and head are glowing yellow; Robin's breast is really ruddy; the colors of all male birds are as pure and fresh as though they had just emerged from a Turkish bath; while some cranes and Herons grow special plume-like feathers as a wedding decoration.

Young birds always take on inconspicuous colors compared with those of the most conspicuously dressed parent. Usually they are the colors of the female. When parents are alike, or nearly so, as with Robins and Blue Jays, the young are not quite like either. In some cases where parents are unlike, as with Rose-breasted Grosbeaks, the male and female young differ enough in plumage to be told apart. The young of course need color protection.

Many young birds, like Prairie Chickens and Ducks, are covered with downy coats. It requires several months for them to acquire their first full plumage. Other birds, like the Orioles, require two or three seasons to gain the full dress of the male.

The plumage of birds, even of the same species, seems to vary with climate, rainfall, and character of the region inhabited. For example, birds of the arid plains of the west are generally lighter colored than their cousins of the east or south. The Western Meadowlarks of our prairies and bad lands are lighter than the Eastern Meadowlarks of Illinois. The same is true of the Horned Larks, which vary considerably in different parts of the country. This fact also would seem to be a phase of protective coloration. The lighter colored birds are most like their surroundings on sandy soil, volcanic ash or where the short grass is parched and dry during most of the summer.

The more deeply we study into Nature's secrets the more evident it becomes that all nature is one, fitted part to part, and that each part contemplates all the rest. 


\section{BIRD MIGRATION}

We who live in the Northern Hemisphere are peculiarly fortunate in the privilege we have of viewing a bird procession twice a year that spreads over the whole of North America to nest. Mr. Wells W. Cooke says, "South America has almost no migratory land birds, for bleak Patagonia and Tierra del Fuego offer no inducements to these dwellers of the limitless forests of the Amazon." (Department of Agriculture, Bulletin No. 185, p. 4.)

There are four classes of birds with respect to migration: (1) permanent residents; those that do not migrate; (2) summer residents; those that come to us from the south in spring and return in the autumn; (3) winter residents; those that come to us from the north in the autumn and return in spring; (4) transients, or migrants; those that pass through our State on their way north in spring and again when they return south in autumn.

The general direction of bird migration is north and south, but with many species this direction may swing at times to east and west. Many Snipes and Plovers, for example, which spend the winter in South America, come north across the Gulf of Mexico, then up the Mississippi Valley, and nest in the interior of North America. In the autumn they take an easterly course to the Atlantic coast, thence south to their wintering place. The Bobolinks that nest in the northwest go to their winter home in South America by the roundabout way of Florida, and the Connecticut Warblers come north through the interior of the United States and return south along the Atlantic coast.

The reason for these circuitous routes is not well understood. Generally speaking, birds migrating follow "mountain chains, coast lines and particularly river valleys," but there are so many exceptions that other causes evidently enter into the problem. At present in South Dakota many birds are extending their range westward with the growth of trees. These birds will follow the migrating routes by which they come, returning first east and then south. Many birds follow such a route because their range has been extended in this way. 
Some think that the ice age crowded the birds southward from their ancient home in the Arctic Regions, which at one time had a temperate climate. Geological changes, such as the upheaval of mountain chains, the rise or subsidence of large areas of land, doubtless enter into the problem; evidently all migratory routes are very ancient in their general outlines.

Another question that may not be answered with too great assurance is, Why do birds migrate at all? What has already been said suggests an ancient and long standing habit, which doubtless has something to do with migration. The cold of our winters is probably not so large a factor in migration as it is usually supposed to be. All birds are very warm blooded, and many of them endure our coldest winters without undue hardship unless caught in some exceptional storm or heavy snowfall. A few birds which usually go south in autumn frequently remain during the winter if certain food is plentiful. In South Dakota the writer has seen Western Mourning Doves and Western Meadowlarks in January, and Blackbirds have been seen feeding in cattleyards in the middle of our coldest winters. Robins, Bluebirds and Northern Flickers are frequently seen at Vermillion in winter, especially when wild grapes are abundant. A few years ago a flock of thirty or forty Robins was seen on the University campus and in adjoining ravines in midwinter.

The supply of food would seem to be a much larger factor than the need of warmth. In many cases the character of the food eaten would seem to affect the distance of migration. All insect eating birds, such as Swallows, Swifts, Flycatchers, Vireos and Warblers, must leave our winters and find summer lands where insects abound, which of course they do by going to the Southern Hemisphere. Snipes, Rails and Woodcocks, which gather their food around open water or in moist places, cannot live where everything is frozen. Birds that live on both insect larvæ and fruit, like Flickers, Robins and Bluebirds, need not go as far south as wholly insectivorous birds. Flickers do not go far south and Robins and Bluebirds winter in our Southern States, while the insectivorous birds push on for the most part into Central and South America. 
We must be careful, however, not to make the food factor or any other factor explain too much. Mr. Frank M. Chapman is probably right in associating bird migration with the homing instinct. It is simply natural for all animals at the mating season to want to get away and be alone. Birds can best do this by distributing themselves over the entire country. Indeed some of the birds remain in the north only long enough to nest and rear their young to full strength. The familiar Yellow Warbler, the common Orchard Oriole, and the less well known Redstart, are all leading their broods on the return journey southward before the middle of July.

It is quite as natural that the mating instinct should be associated with places as with time. And after all possible explanations have been made the most fundamental fact is that birds have been made so. This fact becomes increasingly significant when we consider that birds not only scatter over the entire country during our summer, but that every place in Nature - the pond, the shore, the grass that skirts it, the open fields, the woods, the orchards, every place to our very doors-has its birds. Each bird has its special habitat for nesting and feeding, and each is adapted to its place. They have been made so.

Although, as indicated above, it is natural for birds to migrate so as to gain as much seclusion as possible at nesting time, birds love to migrate in company, the closeness of the companionship varying greatly with the species. Before migration in the autumn one may see Meadowlarks and Robins gathering in loose companies. In the same way several species of Blackbirds, such as Red-wings, Yellow-heads, Cowbirds, Grackles and others, gradually draw together before going south.

While camped near the badlands in the eastern part of Pennington County in late August, 1914, the writer saw Western Lark Sparrows, Lark Buntings and Cowbirds flocking together, resting together under shady creek banks, and feeding together. Whether they were simply gathered about "water holes" in a country where water was scarce or were beginning to associate preparatory to migration, one may not say. The writer has seen Western Yellow-throats and Lazula Buntings feeding together in late July in weeds and thickets of the Missouri River bottom 
in Corson County. On a wooded island in the Missouri River in August, 1919, Black and White Warblers and Chickadees were seen a number of times feeding together; and in September, 1918, English Sparrows, Bronze Grackles and Robins were observed at Vermillion roosting at night in the same trees. Prairie Chickens gather in large flocks in winter and remain associated until the next breeding season. Crows are seen in winter in large flocks, and thousands of them often frequent the same "roost" at night. Ducks and Gulls often gather in exceedingly large flocks to migrate; and in the height of the migrating season one will often count half a dozen different species of Warblers in as many minutes. They travel in large, loose companies of many species. In the spring many kinds of Sparrows migrate together. Often the Juncos are associated with them; and the Olive-backed, Gray-cheeked, and Veery Thrushes are found in company.

In South Dakota there are perhaps twenty-five species known as "residents," and yet few of these spend the winter in the immediate ricinity of their summer homes. The Cardinal, Quail, Screech Owl, Chickadee, Gray Ruffed Grouse, Canada Jay, and perhaps Downy Woodpecker, would about complete the list. The Cardinal both nests and winters at Vermillion. The Quail seldom goes a mile from its nesting home. There is evidence that Screech Owls do not go far from the place where they were hatched. The same Chickadees that feed at your bird table in winter will build their nest in your yard in summer; and "Downy" may be seen in early autumn excavating his winter home.

But most of our "residents" doubtless migrate a little way. Prairie Chickens raised in the northern part of the State, where there is still much prairie grass and wheat stubble, gather in flocks and drift to the cornfields of the southern part of the State to pass the winter. Clay County raises few Prairie Chickens, but feeds many large flocks when the ground is covered with snow farther north. The Prairic Sharp-tailed Grouse nests in the western part of the State, but moves eastward more or less to spend the winter.

Crows, Hawks, Hairy Woodpeckers, and most Owls that 
winter in the State were very likely raised some distance farther north; and yet such questions are very difficult to settle. We have Crows, Hawks, Owls, Downy and Hairy Woodpeckers, and sometimes Flickers, summer and winter. Are they the same ones? Some think that the greater portion of the bird procession simply "moves up"; that is, with many species those that winter farther north go farther north to nest, while others come from farther south to nest where the first wintered, and so on. However this may be with numerous species, the exceptions are many and marked. For example, the Arctic Tern summers in the North Polar regions and winters in the South Polar regions, seeing practically no darkness the year round. The Golden Plover nests in northern North America and winters in southern South America.

One seeing birds in flight would think that they migrate at tremendous speed, but the average for all species is not over twenty-five miles a day. Land birds that migrate by day do not average so much, some of them not over half of it. Mr. Wells W. Cooke shows that the van of the migrating procession, though constantly changing in bird personnel on account of birds dropping out when they have reached their nesting places, moves with increasing rapidity as it comes north. He says: "The average speed of migration from New Orleans to southern Minnesota for all species is close to twenty-three miles a day. Sixteen species maintain a daily average of forty miles from southern Minnesota to southern Manitoba; and from this point twelve species travel to Lake Athabasca at an average speed of seventy-two miles a day, five others to Great Slave Lake at 116 miles a day, and five more to Alaska at 150 miles a day."

Both the time of arrival and speed would seem to be governed largely by temperature. The Canada Goose and the Robin move at the same speed as spring temperature, which is $35^{\circ} \mathrm{F}$. The hosts of Warblers come with the blossoms, which usually appear at a certain general temperature; and temperature moves north with increasing rapidity as the season progresses. This is especially true in the Northwest, where it is affected by the Chinook winds.

In addition to the regular migration of birds there are also 


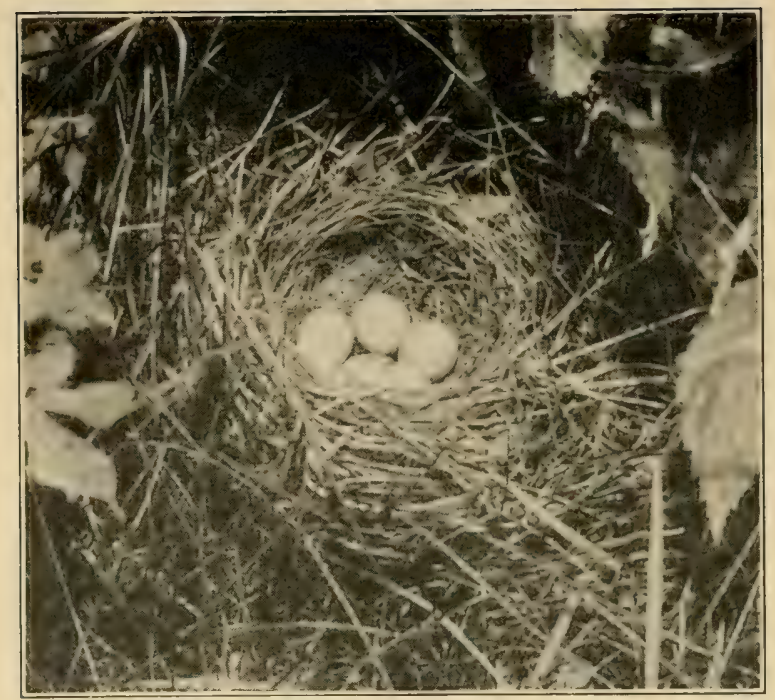

CHEWINK'S NEST WITH

TWO ENEMY COWBIRD'S EGGS

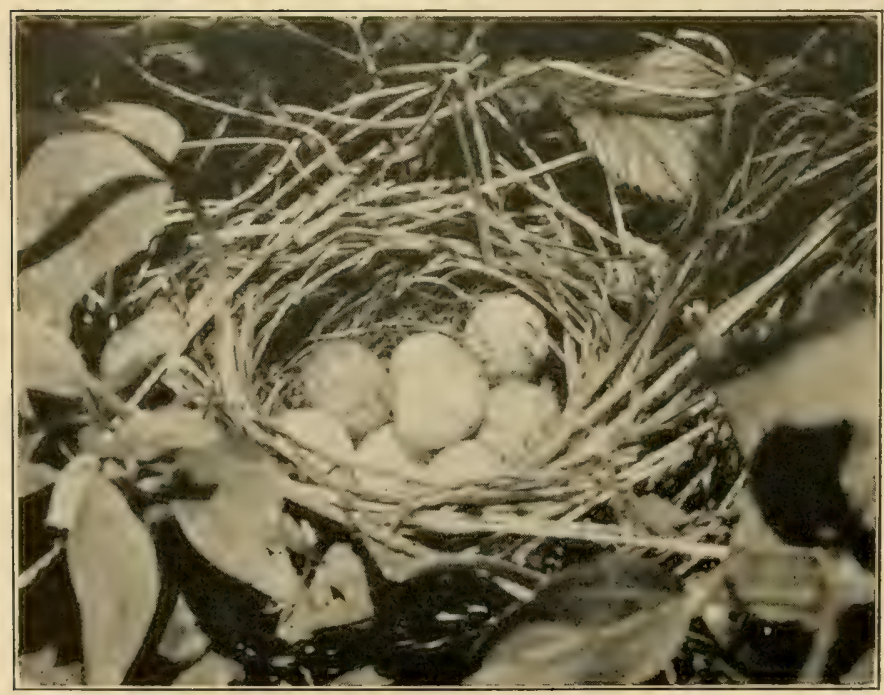

YELLOIV-BREASTED CHAT'S NEST

WITH FIVE ENEMY COWBIRD'S EGGS 
occasional migrations. A noted instance of this kind occurred in 1904, when heavy snows in the northern regions brought the Lapland Longspurs to South Dakota on the wings of a storm in great numbers. The writer of this chapter was returning home about 10 o'clock at night. A keen north wind was blowing, and the air was filled with snow as fine as sifted flour. It was the beginning of a vicious storm. Several times he stopped to listen. The storm seemed filled with birds moving southward. Their sweet calls were heard in every direction. The next morning Vermillion was filled with dead and wounded birds. Becoming bewildered in the storm, they had been hurled against buildings, telephone poles and wires. Such migrations are not uncommon and seem to be occasioned by lack of food, or by the covering of food by snow in the birds' usual winter habitat.

The great majority of birds migrate at night; noted exceptions are the birds of prey, such as Hawks and Vultures, and birds that gather their food on the wing, such as Swallows and Swifts. Other birds, such as Ducks and Geese, seem to migrate partly by day and partly by night.

It has generally been thought that birds migrate at night to avoid attack by their enemies. It seems reasonable, however, to suppose that the food problem is a larger element than the safety problem. Swallows and Swifts must migrate by day to supply themselves with food. Hawks and Vultures have better opportunity for securing food in the course of the day's migration than they would have by migrating at night and resting in some particular place during the day. The food of the great host of small birds is such that they must spend practically the whole day seeking.it. If they migrated by day they would not be able to secure sufficient food, for they cannot search for it by night. Ducks and Geese, of course, need only to descend into any corn or wheat field for a few hours, morning and evening, in the course of flight. This is their regular method of feeding when they remain in one locality.

Bird flights are preferably upon still, clear nights, and are thought to reach at times an altitude of at least three miles. If a storm is raging, the birds cannot hear one another's calls and, 
becoming confused and flying low, often perish by dashing themselves against monuments, light houses, telegraph poles and wires and even the sides of buildings. It is stated upon the best authority that "over 1,500 birds have been found dead at the base of the Bartholdi statue in New York harbor in a single morning, and 230 birds of one species (Black-poll Warblers) were killed in a single night by the Fire Island Light. The Washington monument, though not illuminated at night, causes the death of hundreds of birds annually."

Looking through a telescope focused on the moon during migrations, the observer sees many birds cross the moon's disc. In this way the direction is noted, their height calculated, and often even the species recognized. The multitude of feathered migrants that fill the air at such times may be discovered, at least in part, by counting the calls as the birds pass.

The writer stood one evening in early September on the shore of Pickerel Lake, in South Dakota, and watched the passing of Franklin's Gulls. They flew southward in great streams. When one stream had passed, and what seemed a few belated stragglers were hurrying forward, another stream would appear in the distance, then another, and another. For half an hour he watched them and wondered if there was to be no end. A year later, and within a few days of the former date, he witnessed the same beautiful sight a second time.

So regular are the seasonal conditions, so constant also is the habit of most birds, that any one who observes dates can tell within a few days when any bird will appear.

A sudden drop of temperature during spring migration will often cause birds which otherwise would pass on, to remain about for days. Black Terns have been known to linger even for weeks as though settled for the summer. A pleasant autumn also will retard the fall migrations of many of the feathered folk, especially those that come north early in the spring, and do not winter far south. In ordinary seasons and weather, however, as stated above, the migration of birds is surprisingly regular.

The males of most species arrive a few days ahead of the females. Male House Wrens will carry sticks into three or four 
houses while waiting for a possible mate to come and choose between them; and male Red-winged Blackbirds may be seen in considerable flocks before the females arrive. One would be glad to think that bird migrations were their honeymoon trips, but most of them do not mate until they arrive in the region where they are to nest.

As far as evidence has been collected it tends to show that the same group of birds returns to the same region year after year. Lack of sufficient data forbids the reaching of definite conclusions, yet observers have often noticed the return even to the same yard of individuals with some peculiar characteristic, such as a white feather, a drooping wing, only one leg, or a familiarity with premises not shown by other members of the species. In Audubon's "Birds of America" he tells of fastening silver threads on the legs of young Phoebes along the Schuylkill River in Pennsylvania, and the next summer having the satisfaction of finding two females on nests in the same vicinity with the silver thread on their legs. The banding of young birds would not only help to determine this question but would assist materially in solving other questions of migration such as routes, speed and regularity of seasons.

The strangest thing at present in the field of bird migrations is that the Chimney Swifts, so familiar to everyone in summer by their nervous flight and constant chippering, gather in great swarms on the Gulf Coast in autumn and then suddenly disappear. No one knows where they pass the winter. 



\section{PART II \\ LIST AND DESCRIPTION OF BIRDS OF SOUTH DAKOTA}




\section{FAMILY COLYMBIDÆ, GREBES; FAMILY GAVIID后, LOONS}

Among water birds Grebes and Loons are known as the Divers. Six species of Grebes are found in North America, and five of them have been taken in South Dakota. The other species, known as the Mexican Grebe, is found in the extreme southwestern part of the United States.

Of the five Loons inhabiting North America only one can be called native to South Dakota, and this one is quite rare in the State.

All Grebes and Loons have legs set farther back on their bodies than other water birds. They are therefore rapid and graceful divers and able to swim long distances under water. So quickly can they dive that when shot at three or four rods away they disappear in the interval between the flash of the gun and the striking of the shot.

Neither of these species is edible. The Grebes are not only harmless but useful, feeding on insects and larvæ in or about water. Loons feed on small fish and other aquatic forms. Neither family is gregarious; hence one sees only one or two individuals at a time.

\section{Western Grebe (Aechmöphorus occidentalis.)}

This Grebe is about twenty-six inches in length (from tip of bill to end of tail), and is the largest of the Grebe family. Body gray; throat and breast white; crown and back of neck black in summer and gray in winter. A specimen in the University Museum, taken in Hamlin County by Mr. H. E. Lee, is in winter plumage. This is a western species and a rare migrant in South Dakota, although it formerly nested in Devil's Lake, North Dakota.

\section{Holboell's Grebe (Colymbus holboelli.)}

Also a rare migrant in South Dakota and slightly smaller than the Western Grebe.

Back nearly black; belly white; crown black; cheeks and throat white; fore-neck light brown in adults and gray in young. The specimen in the University Museum is a young one and was taken in the Bellefourche Reservoir, Butte County. Winters chiefly along the sea coasts. 


\section{Horned Grebe (Colymbus auritus.)}

A rather rare bird, but it probably nests in the northeastern part of our State. It is slightly smaller than a Blue-winged Teal. Crown and throat black with a small buff crest extending back from the eyes; neck buff, shading to darker on the back.

4. EARED Grebe (Colymbus nigricollis californicus.)

This Grebe is about the size of the last and very similar in plumage except that the buff crest is smaller and the neck black. It is more westerly in range and probably does not nest in South Dakota, although specimens have been taken in the State.

\section{Pied-billed Grebe (Podilymbus podiceps.)}

About the size of a Green-winged Teal, and commonly called "Hell Diver." Brownish black above with belly nearly white; throat black; a black band around the light brown bill. In winter the throat changes to nearly white and the band on the bill disappears. A common summer resident, thoroughly at home in the water, nesting over most of the State in rivers, lakes and ponds. The nests are carelessly built, usually on clumps of moss or bog, but frequently on old muskrat houses. The seven or eight bluish eggs hatch in about twenty-one days. The young immediately take to the water and remain with the mother until old enough to care for themselves.

\section{Loon (Gavia immer.)}

This fine bird is sometimes called the Great Northern Diver. It is not abundant in South Dakota but individuals may be seen on our largest lakes during summer. A specimen in the University Museum was taken in the Vermillion River, Clay County. The black head, white belly, and distinctly black and white markings on neck and back of the summer plumage contrast strangely with the dull gray of the winter dress. At present these birds rarely nest within our borders but prefer to rear their young farther north, widely separated from mankind. The nests are usually on an island or point of land and near the shore, so that the birds when disturbed can immediately escape into the water and dive.

Their food consists of small fish and other aquatic forms. They are not edible. 


\section{FAMILY LARID死. GULLS AND TERNS}

\section{Herring Gull (Larus $\overline{\text { Argentatus.) }}$}

The largest of our Gulls. Though only migrants in South Dakota these fine birds are quite common for a few days in the spring, feeding on dead fish and garbage along the Missouri River. Head, neck and belly white; back and wings gray, with white spots on the end of the larger black wing feathers; feet webbed; young streaked with gray over the entire body. They breed from the Great Lakes northward.

\section{Ring-Billed Gull (Larus delawarensis.)}

Some seasons this Gull is quite common in migration. It is doubtful, however, if it nests in our State at present. It has been reported as nesting abundantly on an island in Devil's Lake, North Dakota. Head, neck, and under parts nearly white; back gray; largest wing feathers black, with spots on tips; bill greenish, with black band near tip. The plumage of this Gull is very similar to that of the Herring Gull but the bird is smaller.

\section{Franklin's Gull (Larus franklini.)}

The most common of the Gulls in South Dakota. They migrate from the south in May and are seen in flocks hovering over sloughs and fields, the birds occasionally darting to the surface of the water or to the ground for a choice morsel. This is the Gull that follows the plowman and frequently lights in the furrow to hunt for grubs and other insects. Head and neck black; breast white; back and wings bluish gray to black on larger wing feathers, which have white tips. They nest around sloughs in the northeastern part of the State.

Most of the Gulls of North America inhabit the seacoast, but the three just described spend part of the summer in the interior and are of great economic value as scavengers and insect destroyers.

No man should be guilty of shooting a Gull under any conditions. It is not edible, and its food during the entire year consists of destructive insects and dead animal matter found on or near water. 
According to the United States Biological Survey, Farmers' Bulletin No. 497, from ninety-three stomachs of the Franklin's Gull examined it was found that during the breeding season grasshoppers constituted over forty-three per cent, and during September and October over eighty per cent of their food. All Gulls are valuable to the farmer, and he should use every effort in his power to see that they are protected from the gunner.

Instances are on record of Gulls coming to the rescue of early settlers when insects were about to destroy their crops. One such instance is described by the Hon. George A. Cannon of Utah, in the Farmers' Bulletin above referred to. In 1848 the Mormons had sown their first crop of wheat, with good prospects. Then, he says: "Black crickets came down by the million and destroyed our grain crops; promising fields of wheat in the morning were as smooth as a man's hand at nightdevoured by the crickets. At this juncture sea gulls (California (iulls) came by hundreds and thousands, and before the crops were entirely destroyed these gulls devoured the insects, so that our fields were entirely freed from them. The settlers at Salt Lake regarded the advent of the birds as a heaven-sent miracle. I have been along the ditches in the morning and have seen lumps of these crickets romited up by these gulls, so that they could again begin killing." The bulletin says, "These lumps of crickets were undoubtedly pellets of the indigestible parts habitually disgorged by the birds." Gulls have ever since been held in reverence by the Mormon people. In October, 1913, a monument, said to have cost $\$ 40,000$, was erected to the memory of the birds that saved these early settlers from a serious famine.

60. Bonaparte's Gull (Larus Philadelphia.)

This Gull is often seen in large flocks during the fall migration in our State.

About fourteen inches in length and very similar in appearance to the Franklin Gull but the tip of outer wing feathers is black and it does not have the rosy tinge on its breast that the latter may have.

It breeds in Canada and northward.

64. Caspian Tern (Sterna caspia.)

The largest of the Terns and slightly larger than the com- 
mon Crow. It has a black cap, white neck and belly, and gray wings and back. The dull orange bill changes to red during the mating season. No doubt this bird is rather rare and migratory in South Dakota, yet since most Terns and Gulls are similar in color and size one may sometimes be mistaken for the other. They may be distinguished in flight by the fact that the Tern usually carries its bill pointed downward while the Gull carries its bill pointed ahead in line with the body. Another distinguishing mark is that the Terns usually seen in our State have forked tails.

Terns are not scavengers like the Gulls. Their food consists almost wholly of aquatic forms taken alive, part being larvae of insects injurious to the farmer, and the bulk of the rest small fish not useful to man.

\section{Forster's 'TeRn (Sterna forsteri.)}

This graceful bird is smaller than the Caspian Tern though similar in color, the tail feathers being darker. The tip of the orange bill is also dark.

It comes to us in migration, when it may be seen sailing over lakes and rivers and darting into the water after small fish or insects.

\section{Common TeRn (Sterna hirundo.)}

This bird is rare even in migration in South Dakota. It is about the size of the last, except that the tail is shorter. Under parts dusky; back gray; crown black; bill orange tipped with black.

\section{LEAST TERN (Sterna antillarum.)}

As the name implies, this is the smallest of our Terns. It is reported as breeding in South Dakota. Forehead white with black crown; gray back, and white below.

\section{BLACK TERN (Hydrochelidon nigra surinamensis.)}

This is preeminently our Tern. A common summer resident, nesting in marshy places in the eastern part of the State, where it may be seen sailing gracefully over water and reeds, feeding on land and water insects, or frequently resting on wire fences that run through ponds and marshes. 


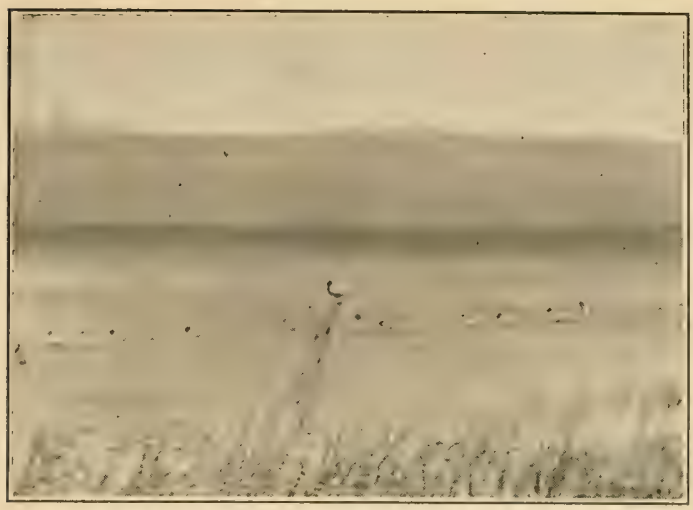

BLACK TERNS IN MIGRATION

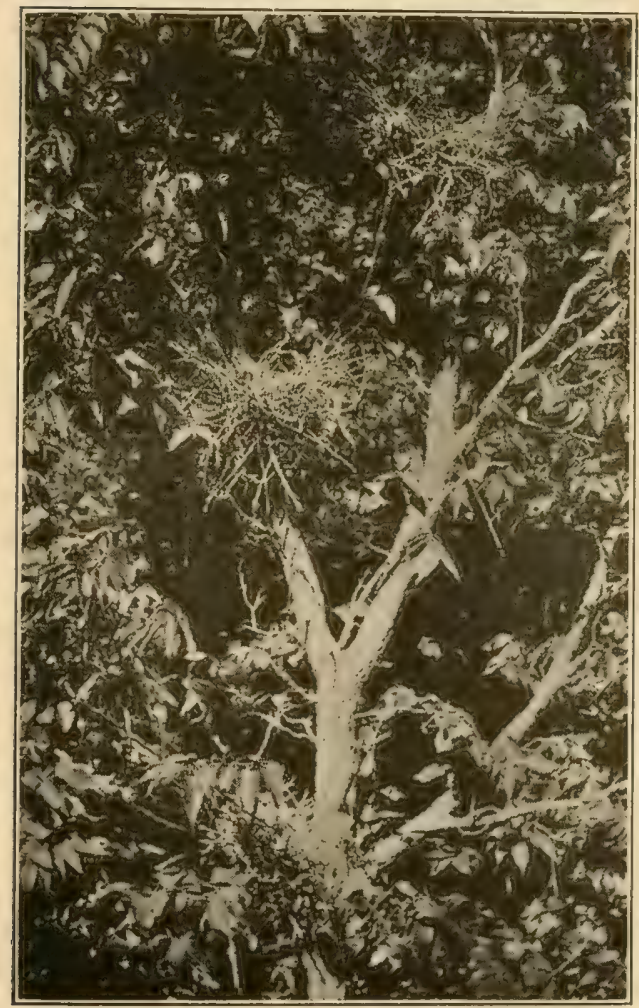

COLONY, NESTS OF THE

BLACK-CROWNED NIGHT HERON 

It would not surprise us to hear of an occasional nest of any of the migratory Gulls or Terns being found in the northeastern part of the State, for those that are now stragglers doubtless nested in the State when the country was new.

\section{FAMILY PHALACROCORACIDÆ. CORMORANTS}

\section{Double-crested Cormorant (Phalacrocorax auritus auritus.)}

This beautiful bird is a rare migrant in the eastern part of the State and probably does not nest here. Three specimens taken from this locality are in the University Museum.

Head, neck and under parts black; back brown mixed with black; throat orange; tufts on sides of head just above eyes during breeding season; tip of bill hooked. They use the strong tail feathers as a third leg in standing.

\section{FAMILY PELECANID瓜。 PELICANS}

\section{White Pelican (Pelecanus erythrorhynchos.)}

We have the Pelicans only in migration when large flocks are seen in May resting on sandbars along the Missouri River. Later they may be found for a few days on any of the larger lakes in the eastern part of the State. They are the last of our large swimmers to come north in spring, and the first to return south in autumn. Their nesting haunts at present are in Canada, Yellowstone Park, Utah, California, and Oregon.

In water they are sluggish, which probably accounts for many of them being shot every year in the State, although they are not edible.

The plumage is white, save for the black outer underwing feathers. They measure about five feet from tip of bill to end of tail, but the long yellow bill, with pouch underneath, takes up at least twelve inches. The pouch is probably not used for carrying a supply of food, as many think, but for scooping up minnows in shallow water. The regurgitated food is deposited in this bag, and from it the young feed.

\section{FAMILY ANATID瓜. DUCKS, GEESE, AND SIVANS}

This family is divided into five sub-families: Merginæ, 
Mergansers; Anatinæ, River Ducks; Fuligulinæ, Sea Ducks; Anserinæ, Geese; and Cygninæ, Swans.

\section{SUBFAMILY MERGINAE. MERGANSERS}

The Mergansers are represented in North America by three species, all of which have been taken in South Dakota. Since the hind toe is webbed, they are classed by some authors as Sea Ducks. They are very appropriately called Fish Ducks, as they have narrow, round bills with saw-like teeth, showing that their habits of feeding are different from those of the true Ducks. The Mergansers are seldom used for food in our State; since they fced almost exclusively on fish and frogs their flesh has a "fishy flavor." In migration they are among the last of this family of birds to go south, and are never seen in large flocks like true Ducks.

\section{Merganser (Mergus americanus.)}

"Fish Duck," "Sheldrake."

These are about the size of Mallards. The male has a very dark blue head, white breast and belly, white and black wings, and gray back. The female, entirely different from the male in plumage, has white chin, reddish brown on crown and crest, white under parts, and gray back.

While a few pairs may occasionally nest in South Dakota, their nesting locality is much farther north. A few are shot each year in migration by hunters.

\section{Red-breasted Merganser (Mergus Serrator.)}

Smaller than the American Merganser. The dark green head of the male has feathers longer than the head of the American. Breast brown with black spots; under parts light; wings whitish; back black. The female has crown ashy brown; back gray; and the end of wing feathers white. Migratory only, as their nesting grounds are well towards the Arctic Circle.

\section{HoOded Merganser (Lophodytes cucullatus.)}

This is the smallest of the Merganser family. The male has a large black and white hood, black neck, white under parts, and black back. The female is similar but with brownish head and gray neck. These birds summer occasionally in South Da- 
kota, sometimes placing their nests in hollow trees near water.

In identifying the Mergansers, one must continually bear in mind not only the difference between species but the wide difference between male and female of the same species.

\section{SUBFAMILIES ANATINA AND FULIGULINA. DUCKS}

The Duck family is a large and important one. No fewer than twenty species are found in South Dakota either as summer residents or in migration. Since the federal game laws prohibiting spring shooting were enacted there is a marked increase in numbers, and it is hoped that public sentiment will become so strong that everyone will discourage the violation of the game laws.

Ducks as a rule do not feed on injurious insects and, while a few species consume quantities of obnoxious weed seeds, their chief economic value is in the food they supply for mankind.

One of the chief characteristics of the Duck family is the marked color contrast in plumage between sexes. The plumage of the young of the first year in most species resembles that of the female. Females of Mallards, Black Ducks, Teals and Shovelers exhibit a marked similarity to the common breeds of barnyard Ducks.

Ducks are usually separated into two divisions: River Ducks and Sea Ducks. River Ducks embrace Mallards, Teals, Shovelers, Pintails, Wood Ducks, Gadwalls, Baldpates and Black Ducks. The most common species of Sea Ducks in our State are the Canvasbacks, Redheads, Scaups, Scoters, Golden-eyes, Ruddy Ducks and Buffleheads.

The distinguishing feature of the Sea Ducks is the large webbed hind toe.

\section{MaLlaRd (Anas platyrhynchos.)}

This fine bird is the largest of our edible Ducks, and an abundant breeder and migrant in the State. Indeed it is more or less common over the whole northern hemisphere. The male adult has a green head, white neck ring, brown breast, purple wing patch, with the balance of body mixed with gray. The female is uniformly buffy streaked with black, except for the purple wing patch bordered with white. Most of our domestic breeds are descendants of this species. 
Mallards are not particular about their food, but are at home in shallow ponds or sloughs of the prairie. In the fall they often gather in large flocks and feed in stubble and cornfields. They are inclined to nest farther from water than most species, and have even been found nesting "out" on the prairie. They have been known to build their nests on the tops of old haystacks.

Because the nesting grounds of all our Ducks are being curtailed each year by the breaking up of prairie and the draining of sloughs, their nesting area is being shifted northward, and in the future we shall perhaps know the Mallard only as a migrant.

\section{Black Duck (Anas rubripes.)}

Usually called "Black Mallard." They are not abundant in the State and occur only as migrants, usually late in the season. About the size of Mallards. Plumage of both sexes very similar, uniformly brown and black, with purple wing patch tipped with black. Legs are not so reddish as the Mallards.

\section{Gadwall (Chaulelasmus streperus.)}

Neck and head gray, top mixed with buff; breast, sides and back barred with gray and white; wings marked with brown, black and white. The wingpatch of the female is ashy gray.

The Gadwall is smaller than the Mallard and nests quite regularly in the State.

\section{Baldpate (Mareca americana.)}

By many this Duck is erroneously called "Widgeon." It is doubtful if a specimen of the true Widgeon has ever been taken in South Dakota, as it is a coast Duck, seldom migrating into the interior. The Baldpate is not so large as the Mallard. It breeds in the State, and some seasons is quite abundant. Males white, or nearly so, on top of head; balance of head and neck gray, except patch of green back of eyes; breast and shoulders buffy; back barred with black and white; wing patch white. Females: head gray; breast and back mottled with buff and black; wing patch black and white; bill smaller than in other Ducks of this State. 


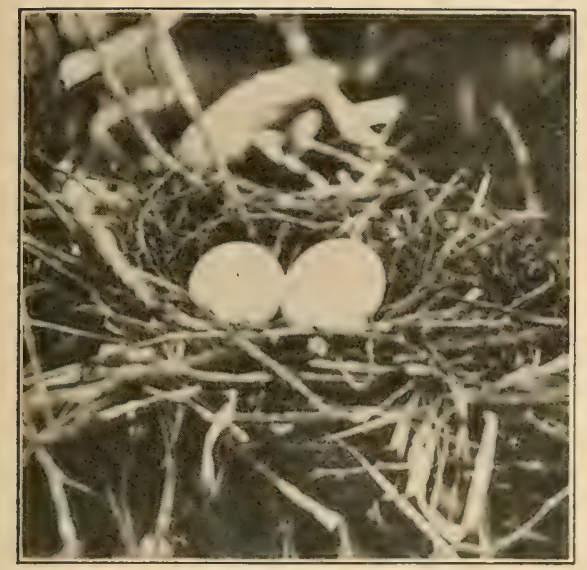

WESTERN MOURNING DOVE'S NEST

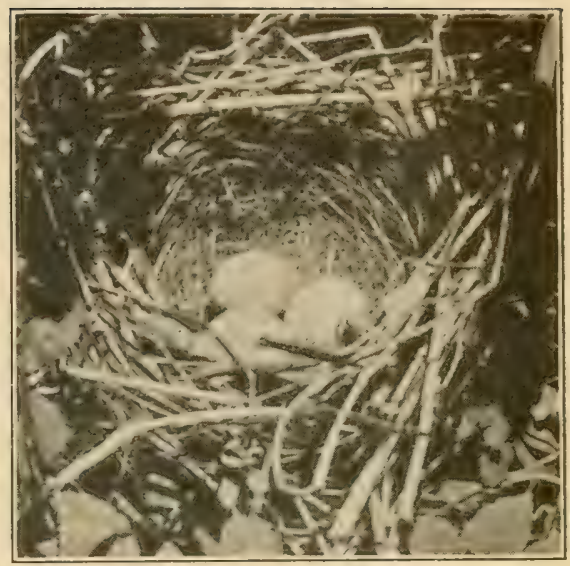

BROWN THRASHER'S NEST

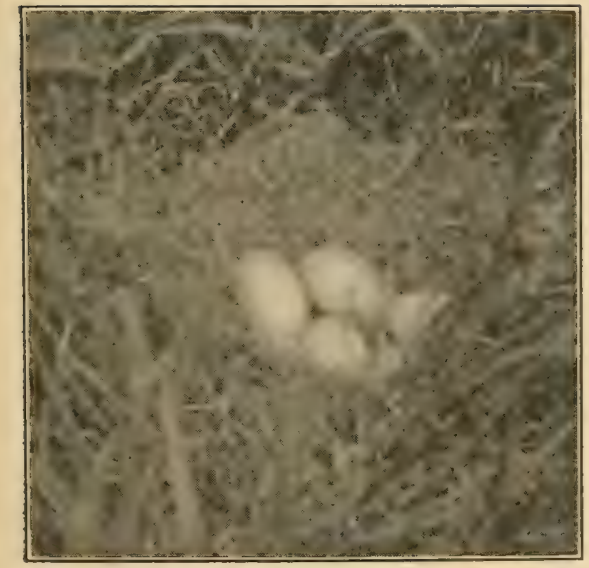

MALLARD DUCK'S NEST

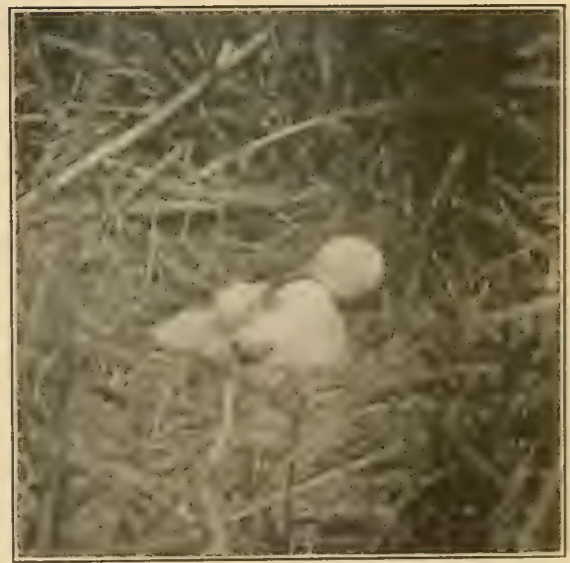

MARSH HAWK'S NEST 

139. Green-Winged Teal (Nettion carolinense.)

One of the smallest of our Ducks and usually very abundant in the State, both in nesting and migration.

Males: head reddish brown, with wide patch of green extending from eyes to nape of neck, slightly crested; breast mottled with black and white; back and sides barred with gray; green wing patch; white crescent on shoulder. Females: uniformly buff and black, with larger spots on the breast, and green wing patch.

\section{Blue-Winged Teal (Querquedula discors.)}

Somewhat larger than the Green-winged Teal and probably the most abundant Duck of the State, breeding freely near small ponds with shallow water. Males: top of head black with white crescent in front of eyes; sides of head slaty; body buff and black, with a patch of blue, green and white on wings. The females are more uniformly buff and black, with blue wing patch.

These little Ducks are sociable fellows and may often be seen feeding with other species. They love shallow water and feed on aquatic vegetable and animal forms. They are the first of the Teals to go south in the fall and usually gather in large flocks when migrating.

\section{Cinnamon Teal (Querquedula cy'anoptera.)}

The distribution of this Duck is given as "west of the Rocky Mountains." It is therefore considered a straggler in South Dakota, although pairs were taken by Mr. F. A. Patton, of Artesian, in Miner County, in 1896, and records are reported from adjoining States. It is about the size of the Blue-winged Teal. Males: head, neck, breast and sides reddish brown; wing like that of the male Blue-winged Teal. The plumage of the female is much like that of the female Blue-winged Teal, but more rusty brown. The bill is shaped like the Shoveler's, but is smaller.

142. Shoveler (Spatula clypeata.)

Breeds locally over the State near lakes and ponds, although it has been known to nest a mile from water. Mr. F. A. Patton reports the following peculiarity in the nesting habits of 
this Duck: The female will select a nesting site in a patch of high, dead grass and lay an egg. As each successive egg is deposited she works at the nest by pulling dry grass up around her, so that by the time all her eggs are laid the nest is finished. In size the Shoveler is nearly as long as the Mallard but the body is much smaller. It is easily distinguished from other Ducks by its long spatulate bill. Male: head green; breast white; back white streaked with black; belly brown. Female: buff and black. Both sexes have a blue wing patch.

At a distance this Duck is often taken for the Mallard, and many a time has the hunter espied what he thought to be a flock of Mallards feeding in a slough and crawled several hundred feet through mud and water, weeds and briers only to find a bunch of "Spoonbills." They are apparently a sociable Duck and are often seen feeding in shallow water with Blue-winged Teal.

\section{Pintail (Dafila acuta.)}

Central tail feathers black, very long and pointed in both sexes, but shorter in the female; head mixed with gray buff; breast and under parts light; back and wings dark gray and more or less barred. Not so large as the Mallard; quite abundant; nests locally over the State.

\section{Wood Duck (Aix sponsa.)}

In color of plumage this is considered the most beautiful Duck in North America. It breeds occasionally in the eastern part of the State, placing its nest in hollow branches of trees or hollow stumps near water. A male was taken in Hamlin County in 1909 by Mr. H. E. Lee, and one the same year by Mr. Alex Walker. During August and early September of 1916 a flock of twelve or fifteen was seen a number of times on a waterhole in the woods four miles west of Vermillion. It was presumed at the time that they were an old female with her brood and that they had been raised in the vicinity.

During the fall these Ducks feed extensively on acorns, and it is said that they also feed to some extent on insects. The bill is small, with upper mandible hooked. Male: a green crest striped with white; sides of head and neck patched with black and white; breast brown specked with white; belly nearly white; 
a white black-edged crescent on the shoulder; wings and back striped with green, brown and white. Female: similar in plumage but much duller; only a very slight crest and with small white patch back of eyes.

\section{REDHEAD (Marila americana.)}

This Duck is nearly as large as the Mallard and in early years was a common breeder, nesting on floating bogs or old rat houses. Male: head and neck reddish brown; breast dark gray; balance of body gray. Female: white throat; balance of body dull brown or gray.

\section{Canvasback (Marila valisineria.)}

This Duck is not as common in the State as some other species but it nests occasionally in the eastern part. Like its relative, the Redhead, it builds a nest on floating bogs, old rat houses, or fastened to rushes over the water. It is slightly larger than Redhead. Male: brown head and neck, usually darker around base of bill; black band in breast reaching around to front of back; back and sides gray; wings ashy gray; tail black. Plumage of the female quite uniformly brownish gray. One characteristic of this Duck is its upper mandible, which gradually slants toward the forehead like the mandible of some geese.

Mr. G. A. Abbott, in "Birds and Nature," Vol. XVI, page 216, says: "Very few of the game birds are more celebrated than the Canvasback. Both sportsmen and epicures find that it meets their highest ideal of game qualities. It flies rapidly and with directness, dives quickly, swims rapidly and withal is remarkably wary and alert. Its flesh is considered incomparably delicious by many, especially if the bird has been feeding on the 'water-celery', an abundant fresh water plant, which is its favorite food. In fact, the Canvasback was given its specific name because of its known fondness for this water plant, which bears the Latin name Vallisneria spir.lis."

148. Scaup Duck (Marila marila.) "Blackhead," "Bluebill."

Nearly as large as the Redhead and some seasons quite abundant in the State. Probaly a rare breeder in South Dakota although it has frequently nested at Devils Lake, North Dakota. Male: head black glossed with green; breast hlack: sides and 
belly light; back barred with gray and white. Female like, No. 147, but feathers at base of bill white.

\section{Lesser Scaup Duck (Marila affinis.)}

The plumage of both male and female is similar to No. 148 , but the bird is smaller. It rarely nests in South Dakota but is common in migration. Both of the Scaups are lovers of deep water and common in the Great Lakes region.

150. Ring-NeCKed Duck (Marila collaris.)

This Duck is smaller than No. 149. Head black; chin white; brown neck ring, whence its name; back and tail black; under parts light. Female similar but more rusty on breast and back. A rare breeder in the northeastern part of the State.

\section{GoLden-EyE (Glangula clangula americana.)}

About the size of the Redhead and common in the State some seasons as a migrant.

Male: green head slightly crested with a round white patch on cheek; breast and belly white. Female: head brown; throat white; breast and back gray. Their summer home is well within the Arctic regions.

\section{Buffle-HEAD (Charitonetta albeola.)}

A rather small Duck. Green head slightly crested; white patch extending back from eyes; neck, breast and belly white or grayish; back black. Female: brown head and neck with white on sides of head; throat and breast grayish brown. Probably seen only in migration.

\section{OLD-SQUAW (Harelda hyemalis.)}

Very rare; seen only in migration. There are only two specimens in the University Museum.

Central tail feathers of both sexes very long and black. Male in summer: black, with some rusty on back; white patch around eye. In winter: head white, with black patch on sides of neck; breast white; black crescent over shoulders. Female in summer: head and upper parts mostly dusky, with whitish patch back of eye. In winter: cheeks, neck and under parts white; breast dusky. Breeds in the Arctic regions. 


\section{Surf Scoter (Oidemia perspicillata.)}

A large Duck. Rare in migration. Male: black, with crown and nape white. Female: above black, breast dusky; belly lighter; white patch at base of bill. In both sexes black feathers extend forward on top of bill. A female in the Museum was taken on Lake Madison by Mr. J. C. Green, of Sioux Falls, in 1914.

\section{Ruddy Duck (Erismatura jamaicensis.) "Butterball."}

Breeds quite commonly in the State, building floating nests in high rushes. A very small Duck, but Mr. F. A. Patton says that "the eggs are of the same size as those of the larger Ducks." Male: crown black; cheeks white; back and neck reddish brown. Female: head dusky; back grayish brown; belly white. Tail feathers narrow and stiff in both sexes.

\section{SUB FAMILY ANSERINA. GEESE}

Geese are intermediate between Ducks and Swans in size and in length of neck. They are the largest of our aquatic game birds and are more terrestrial in their habits than Ducks. They feed almost entirely on vegetable foods-stubble or cornfields, winter grainfields, or tender grass shoots in the water. There is little difference in plumage between sexes; they lack the highly contrasted colors of Ducks. Eight species or varieties, usually called "Wild Geese," are mostly migrants in South Dakota.

169. SNow Goose (Chen hyperboreus hyperboreus.)

Length from tip of bill to end of tail about twenty-six inches; all white except the longest wing feathers or primaries, which are black. A western species that breeds in Alaska and is common in South Dakota in migration.

169a. Greater Snow Goose (Chen hyperboreus nivalis.)

Rare; seen only in migration. An eastern variety that breeds in the Arctic regions. Similar to 169 but larger, length up to thirty-eight inches.

169. 1. Blue Goose (Chen caerulescens.)

Rare in migration. About the size of the Snow Goose. Head and neck white; body bluish gray; rump lighter. 
A fine specimen was taken in Minnehaha County and sent to the Museum in 1916 by Mr. C. J. Stringham of Sioux Falls.

170. Ross's Goose (Chen rossi.)

A straggler in South Dakota, but specimens were taken in Miner County in 1890 by Mr. F. A. Patton.

The Ross Snow Goose is much like the Snow Goose in color but the bird is smaller, and the bill noticeably shorter.

171a. White-Fronted Goose (Anser albifrons gambeli.)

Size of 169.1. Forehead white; back gray; breast and under parts light gray spotted with black.

172. CANADA Goose (Branta canadensis canadensis.)

The Canada Goose is the species most popularly known as the "Wild Goose" and has always nested in the State.

It is the largest of the Goose family, the last to go south and the first to come north in migration. The loud "honk, honk," is the foreword of spring. In the southern part of the State the Canada Goose remains until January, or until the last "airholes" freeze over in the Missouri River. In these they rest during the night and much of the day. At daybreak they can usually be seen going out to their feeding grounds.

Length up to forty inches; head and neck black, except throat and cheeks, which are white; body bluish gray but lighter underneath.

172a. Hutchins's Goose (Branta canadensis hutchinsi.)

Similar to 172 but smaller. Length about thirty inches. Seen only in migration. Breeds in the Arctic regions.

172c. Cackling Goose (Branta canadensis minima.)

Similar to 172 a but smaller, with black throat.

Length twenty-four inches. A western variety; breeds in Alaska; migrant in South Dakota.

173a. BRANT (Branta bernicla glaucogastra.)

A rare straggler in our State; breeds in Alaska and migrates east of this territory. Head and breast black; white patches on sides of neck; back gray; under parts nearly white. 


\section{SUB FAMILY CYGNINA. SWANS}

The Swan is the largest of the Family Anatidae, and is hardly considered a game bird. It has a very graceful form and is largely used in a semi-domesticated state in parks and private bird preserves. Only two species are found in America. The Trumpeter Swan is practically extinct, probably only a few specimens remaining in captivity.

180. Whistuing Swan (Olor columbianus.)

Length about fifty-five inches; all white except bill and feet, which are black; yellow spot in front of eyes; nostrils nearer to tip of bill than eyes. Breeds within the Arctic Circle; rare, but a few are reported in migration from the State each year.

181. Trumpeter Swan (Olor buccinator.)

Very similar in color to the Whistling Swan but larger, and no yellow spot before the eyes. The nostrils about midway between eyes and tip of bill.

This beautiful bird nested in South Dakota in the eighties but no specimen has been seen for several years and it is believed to be nearly extinct

\section{FAMILY ARDEID君. BITTERNS AND HERONS}

190. Bittern (Botaurus lentiginosus.) "Thunder Pumper," "SHITEPOKE."

A very common summer resident, especially in the high grassy sloughs of the eastern part of the State, where it nests and makes its home. It stands about eighteen inches high and feeds principally on frogs. At times, when seemingly trying to evade detection, it stands erect with bill pointing skyward. Assisted by the resemblance of its plumage to surroundings it thus secures protection from its enemies. This bird, however, would seem to need no protection. It is not hunted for foor by man, and we have never known it to be eaten by Hawk, Owl, or coyote. Surely any flesh-eating animal or bird would be near to starvation before eating a Bittern. Body very small for size of bird; head small; black patch extending down sides of neck; back and sides buff and brown mixed; lighter underneath. 


\section{LeAst BITTERN (Ixobrychus exilis.)}

This Bittern is a summer resident and nests in the eastern part of the State. It resembles the Heron in shape, but is very small, measuring only about twelve and one half inches from tip of bill to end of tail. When standing erect it is not over nine or ten inches high. These birds live in marshy places among high reeds and rushes. They are usually seen perched on perpendicular reeds where they evade detection by their protective coloration. They are slightly crested. Male: crown and back black; neck and under parts buff streaked with some white. Female: similar, with crown and back brownish.

\section{Great Blue Heron (Ardea herodias herodias.)}

The Great Blue Heron is erroneously called "Blue Crane" by many, probably because it is bluish and has a long neck and legs. They are common over the State. Individuals may be seen feeding or resting along river bank and lake shores. Rarely are two seen together. In August, 1914, however, nine were observed in a small "waterhole" near the Missouri River in Sully County, making their breakfast of minnows. Yet when flushed they took flight separately, going in different directions. The Great Blue Heron stands about three feet high and has a very small body in proportion to the length of its legs and neck. Crown white with black crest feathers; neck and body bluish gray; under parts light. They nest in colonies in trees.

201. Green Heron (Butorides virescens virescens.)

The smallest of the Herons and a summer resident in South Dakota. Crown dark green, crested; neck and breast chestnut brown; under parts ashy; back green mixed with brown and gray. The nest is usually built over water in high rushes, but sometimes in bushes near water.

\section{Black-crowned Night Heron (Nycticorax nycticorax naevius.)}

A common resident over the State in summer, nesting in colonies in trees; much smaller than No. 19t. Forehead white; crown and back dark glossy green; two or three long white feathers on head except during the molting period; wings and tail gray; neck, breast and belly light. The young are a uniform buff and brown. 


\section{FAMILY GRUID压。CRANES}

Cranes are more terrestrial in habit than Herons.

During migration they frequently light in numbers to feed, usually on knolls or in winter wheat or rye ficlds. During the breeding season they inhabit marshy places and their food consists chiefly of aquatic animal forms. Cranes reproduce slowly, rarely laying more than two eggs in one nest.

204. Whooping Cranes (Grus americana.) "White Cranes."

This beautiful bird stands three and one half to four feet high. The forehead is bare and dull red. Plumage all white except the longer wing feathers, which are black. The head of the young is feathered, both head and neck feathers being more or less rusty. There is a young specimen in the Museum the plumage of which is washed with rusty over the entire body. They nest north of us and are seen only in migration in South Dakota.

205. Little Brown Crane (Grus canadensis.)

The range of migration of this Crane is given as "western part of the United States and east to the Rocky Mountains."

The specimen in the University Museum was taken in Walworth County. There is one in the United States National Museum taken in Edmunds County, October 22, 1883. Mr. F. A. Patton, of Artesian, took one in Miner County in 1896. Mr. F. M. Chapman gives the following description: "Length, thirtyfive inches; bill, four inches. Adults: skin of top of head dull red; plumage brownish gray. Young : head feathered, plumage with more or less rusty. Probably very difficult to distinguish from a young or immature specimen of the Sandhill Crane."

206. Sandhill Crane (Grus mexicana.)

This splendid bird is quite abundant in migration and has nested in the State.

In general appearance it is very similar to No. 205, but larger. Length three and one half to four feet; bill five to five and one-half inches. 


\section{FAMILY RALLID Æ. RAILS, GALLINULES AND COO'TS}

208. King RaIL (Rallus elegans.)

Rails are related to Cranes in general structure, but in appearance they are quite different, being much smaller in size. The King Rail is the largest of his tribe and measures about fifteen inches from tip of bill to end of tail. Neck and breast brown; back and wins black and brown; sides and belly barred with brown and white. This bird breeds in the Mississippi River valley and east to the Atlantic coast, and is therefore considered a straggler in the eastern part of the State.

\section{Virginia RaIL (Rallus virginianus.)}

The plumage is similar to that of No. 208, but the bird is smaller, measuring only about nine inches; bill one and one half inches. This Rail is common and breeds in the eastern part of the State. An abandoned nest with eggs was found July 2, 1917, near Lake Preston. The Rails all make their home in wet, marshy places where there is a thick growth of sedges or rushes. They are fleet in the use of their legs but are not adapted to rapid flight.

\section{Sora (Porzana carolina.)}

Slightly smaller than No. 212. Bill three quarters of an inch in length; feathers at base of bill and on throat very dark brown or black; back streaked with brown, buff and white; under parts barred with gray and white. This beautiful Rail is more or less common over the State, nesting frequently in marshy places.

\section{Florida Gallinule (Gallinula galeata.)}

Slightly smaller than the Coot. Head, neck and breast gray; back brownish gray; belly barred with white. The crown plate is red; the feet are not lobed for swimming; and the legs and bill are smaller than those of the Coot. These birds are not nearly so abundant in South Dakota as the Coots but from their similarity in appearance doubtless the Coots and Gallinules are often confused.

221. Соот (Fulica americana.)

The Coots are a sort of connecting link between Ducks 


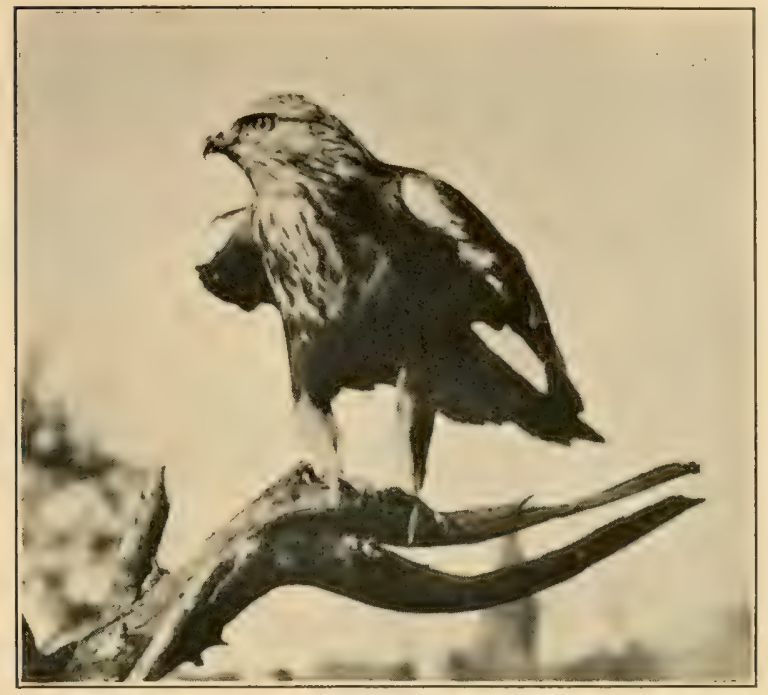

ROUGH-LEGGED HAWK

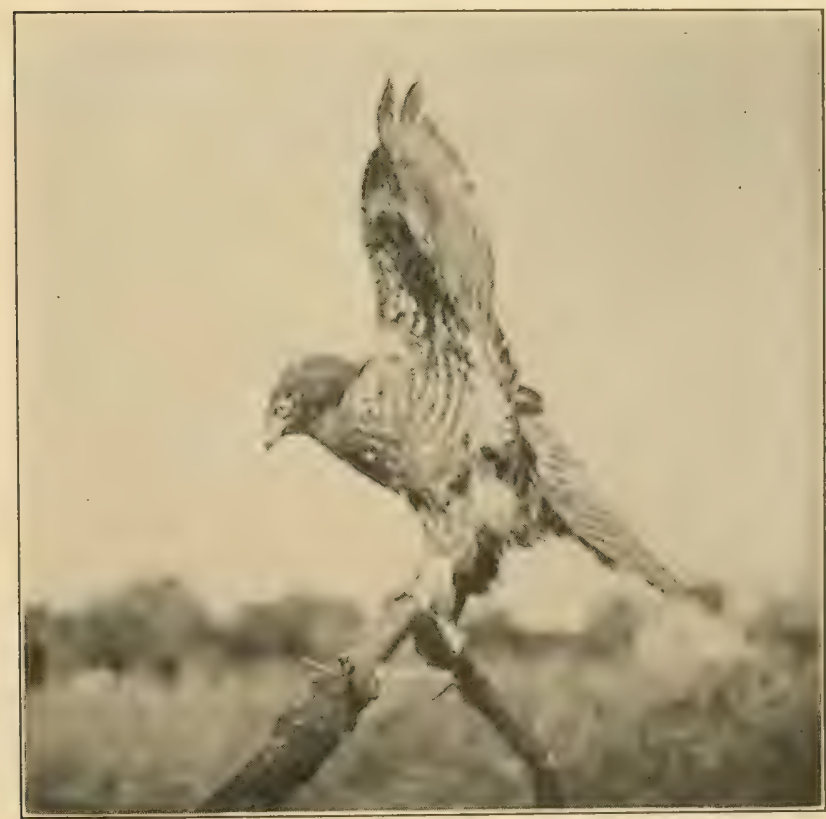

RED-SHOULDERED HAWK 

and Rails, both in general structure and also in size. They are aquatic in habit, having lobed or semi-webbed feet. They are fairly good swimmers but not equal to Ducks. Unlike Loons and Grebes they are not adept divers. The wings of Coots are small in proportion to their bodies, hence they are slow and rather clumsy, both in rising from the water and in flight. Their legs are too short to place them with the waders, but notwithstanding their apparent defects they hold their own fairly well. Probably this is partly due to the fact that their flesh is not esteemed for food.

In regard to the quality of the flesh and the feeding habits of the Coot we quote Mr. H. Waltan Clark in "Birds and Nature," Vol. III, page 131: "During the first few weeks after their arrival in the spring the Coots find plenty of dainty tit bits of succulent vegetation, and they are then very good eating. $\mathrm{He}$ who feasts on them at this time is likely to think of 'Mud-hen' with the accent on the last syllable. Later, however, the food becomes scarcer, and the birds subsist more and more on the rank chara or other similar growths of the lake bottom. The flavor then becomes rank and muddy, and he who feeds on 'Mud-hens' is pretty sure to think of the name with a change of accent."

The general appearance of the Coot is dark slate, although the head and neck are usually darker, and the belly lighter, than the body. The bill is whitish with brown spots near the tip, and the crown plate is brown. The Coot is common over the State, nesting on old muskrat houses or on a bunch of old rushes that are still attached but floating. Their flight in migration is during the night. 


\section{SHORE BIRDS}

This order embraces several families usually called Snipes or Waders. Most of them have long legs and bills, which enable them to procure their food along muddy shores or in shallow water. The Killdeer and the Upland Plover are more terrestrial than the others and frequent our prairies, especially during the nesting season. On the other hand the Phalaropes and Avocets have lobed or partly webbed feet and are fairly good swimmers. - Two species of the Phalaropes, when not nesting, spend much of their time at sea several miles from the coast, feeding on small marine forms. Other interesting characteristics of the Phalaropes are that the females are larger and more brightly colored than the males, and that after the eggs are laid the males do the incubating. It is believed by some authorities that he alone feeds and cares for the young.

In earlier years many of the Shore Birds nested in abundance in our State, but today their former nesting grounds are either under cultivation or in pasture. With no grassy environment and the continual tramping of stock, no safe place is left in South Dakota for the Snipes to nest and rear their young. Their food consists chiefly of insects and insect larvae, consequently the economic value of Shore Birds is very great. Not only do they destroy great numbers of insects which are destructive to crops, but eight species recorded as summer residents of South Dakota devour immense quantities of mosquito larvae. (United States Biological Survey Circular No. 79.) The Killdeer and the Upland Plover eat the larvae of the horsefly. Eight species are known to eat the larvæ of the crane-fly, a pest of the grass fields. Later in summer a large portion of the food of many of our Snipes consists of young Rocky Mountain locusts and grasshoppers. Although their flesh is considered a great delicacy, yet on account of their small size and the fact that they feed upon many of the worst enemies of agriculture, their protection deserves the encouragement of every one.

\section{FAMILY PHALAROPODID王. PHALAROPES}

223. Northern Phalarope (Lobipes lobatus.)

This is one of the "Swimming Snipes" that lives much of 
the time near the coast, and is only a migrant in South Dakota. It nests north of the United States.

Crown dark gray; throat white; sides of neck reddish brown; breast rusty brown; back dark slate streaked with buff; belly white. The male is about seven and one half inches long, the female slightly larger and with more rufous plumage.

224. Wilson's Phalarope (Steganopus tricolor.)

The Wilson is larger than the Northern Phalarope and usually a common summer resident. In earlier years it nested abundantly over the eastern part of the State. Female: crown gray; throat light; a black line extends from the base of the bill down the sides of the neck, blending into chestnut brown; back gray patched with brown; under parts white. The male is slightly smaller, with duller colors and darker crown. This Phalarope is more terrestrial in habit than No. 223.

\section{FAMILY RECURVIROSTRID五. AVOCETS}

225. Avocet (Recurvirostra americana.)

The Avocet, with its extremely long legs and bill and very small body, is an odd looking bird and certainly a true "wader." During August it is fairly common in migration west of the Missouri River and doubtless breeds occasionally in that part of the State. It is about seventeen inches long from tip of bill to end of tail. Head and neck rufous, growing lighter about the base of bill; under parts white; back and wings black and white. The settling up of our wild land is driving the Avocets westward, and their breeding grounds will soon be restricted to the federal bird preserves of the western States.

FAMILY SCOLOPACIDA. SNIPES AND SANDPIPERS

\section{Woodcock (Philohela minor.)}

Swamps and wet woodlands are the natural environment of the Woodcock. It is thereforc a rare visitant in South Dakota, migrating from the east; and yet records of its occurrence are rather numerous. A specimen in the University Museum was taken by Mr. H. E. Lee in Beadle County in 1913.

In contrast with the Avocet the Woodcock is low and 
stockily built and more nearly resembles the true Snipes. Forehead gray; crown black with light brown bars; breast and belly rufous; back and wings mixed with black, brown and gray. Bill about two and three quarters inches in length.

230. WILSON's SNIPE (Gallinago delicata.) "JACKSNIPE."

The Wilson Snipe is common in migration over most of the State, but nests only in the eastern part in marshy sloughs.

Crown and back brown; throat and under parts light; bill about two and one half inches in length.

Like the Woodcock, it has short legs and a long thick bill and secures its food of worms and insect larvæ by probing into the soft moist ground.

\section{DowITcher (Macrorhamphus griseus griseus.)}

This bird is about the size of a Robin and has a rough or pitted bill slightly over two inches long. Crown, back and wings black, margined or barred with rufous; under parts reddish brown spotted and barred with black; rump and tail barred with black and white.

It is an eastern species and out of its range in South Dakota, but in earlier days was no doubt quite abundant. The specimen in the University Museum was taken several years ago in Miner County by Mr. F. A. Patton.

232. Long-BILled Dowitcher (Macrorhamphus griseus scolopaceus.)

Very similar to No. 231 but darker on the under part and with longer bill, averaging nearly three inches. The females are said to be slightly larger than the males.

This is supposed to be the western form of the Dowitcher but it is probably rare in South Dakota today even in migration. Both species breed in the Arctic regions.

233. Stilt SANDPiper (Micropalama himantopus.)

This Sandpiper is about eight incehs long, including the bill, which measures one and one-half inches. The crown, back and wings are black, mixed with white and brown. There is a reddish brown line from bill to eye and extending to the auriculars. The under parts are white, barred with black and brown. 
This is an eastern species and quite rare at present, although abundant in earlier days. Two specimens in the University Museum were taken from near the mouth of the Cheyenne River by Mr. F. W. Smith in 1904.

It nests in the Arctic regions.

\section{Knot (Tringa Canutus.) "Robin Snipe."}

Another rare Shore Bird but reported by Mr. F. A. Patton as a common visitor twenty-five years ago.

Above, reddish brown, mixed with black and gray; breast and belly reddish brown; ten and one half inches long; bill about one and one third inches. Nests within the Arctic Circle.

\section{Pectoral Sandpiper (Pisobia maculata.)}

Fairly common in South Dakota, only in migration. This Snipe nests in the Arctic regions.

It is about nine inches in length; bill one and one eighth inches; upper parts black, margined with rufous or rusty brown; belly white; throat and breast streaked with black; tail pointed.

241. Baird's SandPiper (Pisobia bairdi.)

This Sandpiper also breeds in the Arctic regions and is common in South Dakota in migration.

About seven and one half inches in length; bill about seven eighths of an inch long; grooves in both mandibles very noticeable; upper parts brownish black with neck lighter; longest wing feathers nearly black; belly white; throat streaked with black.

\section{Least SANDPIPER (Pisobia minutilla.)}

This is the smallest of our Sandpipers, being not over six inches in length. Crown and back black and reddish brown, many of the feathers tipped with buff; belly white; breast streaked with black. Seen in South Dakota only in migration.

243a. Red-BACKed SANdPIPer (Pelidna alpina sakhalina.)

A rare migrant in South Dakota; nesting in the Arctic regions. Back and crown reddish brown and black; wings and tail gray; belly black; breast and throat white streaked with black; about eight inches in length; bill one and one half inches and slightly curved. 


\section{Semipalmated Sandpiper (Ereunetes pusillus.)}

This eastern species is a rare migrant in our State and breeds in the Arctic regions. Mr. F. A. Patton of Artesian took specimens in Miner County in 1896.

It is one of the small Sandpipers, averaging slightly over six inches in length. Toes webbed at base; upper parts black and gray; belly white, with breast slightly mixed with black; tail ashy gray.

\section{SAnderling (Calidris leucophaea.)}

Another of the Shore Birds seen only in migration. Unlike its near relatives it has only three toes, and these are not partially webbed, as in the others. It is eight inches long including a bill one inch long. Above, spotted with rusty, black and white; under parts white except breast, which is tinged with rusty brown.

\section{Marbled Godwit (Limosa fedoa.)}

One of the largest of the Shore Birds which probably still nests in the State, but not so frequently as in earlier days. Length, eighteen inches, including a slightly curved bill of four inches; back reddish brown; tail barred with black; under parts much lighter and also barred with black.

\section{Hudsonian Godwit (Limosa haemastica.)}

This Godwit is smaller than the Marbled, being only about fifteen inches long, including a three and one half inch bill, which is slightly curved upward. Above, black, gray and buff : below grayish, barred with rufous and black; usually ocherous on the belly.

In the early days it was probably an abundant breeder in South Dakota and at present it may occasionally be found nesting, but its natural environment is being rapidly plowed up or tramped down by stock.

It feeds mostly in shallow water or along muddy shores.

254. Greater Yellow-legs (Totanus melanoleucus.)

This "Snipe" is fourteen inches long, including a two inch bill. Legs very long, slender and yellow; upper parts grayish black, margined with white; tail barred with black and white; 
under parts white barred with black.

It breeds north of the United States and is usually seen in large, migrating flocks.

\section{Yellow-Legs (Totanus flavipes.)}

The plumage of this "Snipe" is almost identical with that of the Greater Yellowlegs but the bird is only about two thirds as large, with yellow legs comparative longer. It rarely nests as far south as our State and, like its larger consin, is often seen in large, migrating flocks.

\section{Solttary SANDPIPER (Helodromas solitarius solitarius.)}

Another eastern species that breeds north of the United States and is scen in South Dakota only in migration. It is about eight inches long, including the bill, which is about one inch in length. Above it is gray spotted with white. Most of the tail feathers as well as the under wing feathers are barred with black and white. Throat and belly white; breast streaked with brownish gray.

This little Sandpiper is usually seen aione at the water's edge by streams or pools and may be recognized by its continual "teetering" as it hunts for worms and larvae in the soft mud.

\section{Willet (Catoptrophorus semipalmatus semipalmatus.)}

Another Shore Bird with long, blue legs and a rather stout bill two and one quarter inches in length. Upper parts gray mixed with brownish black and buff; below, white mixed with black and buff; larger wing feathers black with a broad white band.

The specimen in the University Museum was taken May 6, 1894, by Mr. F, A. Patton, in Miner County.

258a. Western WILlet (Catoptrophorus semipalmatus inornatus.)

This Willet is similar to No. 258 but larger, and with paler plumage, both above and below, and also with fewer black markings. There is very little buff on the specimen at hand. Probably it nested abundantly here in early days, but it is doubtful if a nest could be found at present, as its favorite breeding grounds have been destroyed by the plow and the pasturing of the low lands. 


\section{Upland Plover (Bartramia longicauda.)}

This Sandpiper is more terrestrial in habits than its relative and is a common summer resident over the western half of South Dakota. Before the prairies were broken up it nested over the entire State. When alighting it has the habit of gracefully extending the wings almost perpendicularly over its back. It is about eleven and one half inches long, including a one and a quarter inch bill. Above, nearly black, with feathers edged with buff; throat and belly white; breast and sides marked with dusky arrows.

This bird deserves careful protection by everyone. Ninety-seven per cent of its food consists of insects, and over one half is made up of insects injurious to crops or stock, such as grasshoppers, crickets, wire worms and cut worms, and larvae of horseflies and cattle ticks.

\section{BUfF-BREASTED SANDPIPER (Tryngites subruficollis.)}

A rare migrant in our State. Length about eight inches. Above, black, the feathers margined with brown; below, buff with black spots.

\section{Spotted Sandpiper (Actitis macularia.)}

This cosmopolitan Sandpiper may be seen during the summer over most of North America. It inhabits the muddy banks of ponds and streams, and is always seen alone. From its "teetering" habit it is often called "Teeter." Seven and one half inches long; brownish gray above, lightly barred with black; under parts white with black spots.

\section{Long-billed Curlew (Numenius americanus.)}

One of the largest of our "Snipes," measuring up to twenty-four inches, including a bill varying in length from four and one half to six and one quarter inches, curving downward. Back and tail black, barred or blotched with buff; belly buff; breast slightly streaked with grayish brown. Its habits are more terrestrial than most of the Shore Birds.

Although not so abundant in South Dakota as in early days it is frequently found nesting on the grassy plains west of the Missouri River. 


\section{Hudsonian Curlew (Numenius hudsonicus.)}

Much smaller than No. 264, only about seventeen inches long. Bill three and one half inches long and curved downward; crown dusky with a light medium stripe; back dusky, slightly mixed with rufous; under parts whitish; breast streaked; sides marked with broken blackish bars.

This Curlew breeds in the Arctic regions but may be seen in South Dakota in migration.

266. Eskimo Curlew (Numenius borealis.)

The smallest of the Curlews, measuring only about thirteen inches from tip of bill to end of tail. The bill is perhaps slightly over two inches long. Upper parts dusky, blotched with buff, tail barred; under parts buff, marked with dusky streaks or bars; throat nearly white.

Breeds in the Arctic regions. In early days it was quite common in migration but is now probably nearly extinct.

\section{FAMILY CHARADRIIDA. PLOVERS}

270. BlaCK-Bellied Plover (Squatarola squatarola.)

This Plover is a rare migrant which breeds in the Arctic regions.

Black and white on back and wings; tail barred; under parts black in adults and white in the young. It has a very small hind toe. The length is about eleven inches, including the bill, which is one inch long. A young specimen in the University Museum was taken by Mr. J. C. Green in Minnehaha County.

272. Golden Plover (Charadrius dominicus dominicus.)

The Golden Plover is slightly smaller than No. 270 and has no hind toe. Above dusky and black, spotted with golden yellow; below black. Whitish lines extend from the forehead over the eyes and down the sides of the neck and breast. The young are lighter above and grayish white below.

It spends its nesting season in the Arctic regions and is found in South Dakota only during migration.

273. KilldeER (Oxyechus vociferus.)

Length about ten inches; crown and back grayish, tinged 
with brown; rump and upper tail feathers rufous; below, white with a black ring around neck and a partial black ring on the breast. It may be recognized by its loud notes uttered while flying, and resembling, "Killdeer! Killdeer!"

It nests commonly over the State, usually laying four eggs in a slight depression on rather bare pastures or gravelly places. It winters in the southern part of the United States.

\section{Semipalmated Plover (Aegialitis semipalmata.)}

This Plover is much smaller than the Killdeer, being only about six and one half inches long. The nape and back are grayish brown; under parts white; one white and one black ring around the neck. Breeds in the northern part of North America; only a migrant in our State.

277. Piping Plover (Aeginlitis meloda.)

Slightly larger than No. 274 but the bill is very short. Above, ashy gray with the crown and sides of breast black; under parts white.

In 1891 this Plover nested abundantly on the sandy shore of Lake Herman, Lake County, but at present it is rarely found nesting in the State.

281. Mountain Plover (Podasocys montanus.)

The Mountain Plover probably nests in the western part of South Dakota, as small flocks have been seen during August feeding in prairie dog towns. About nine inches in length; above, gray and rufous with a black crown band; below, white with an occasional gray tinge on the breast.

\section{FAMILY APHRIZIDÆ. TURNSTONE}

283a. Ruddy Turnstone (Arenaria inierpres morinella.)

Upper parts reddish brown, black and white; throat and belly white; breast black, with a black band extending up the sides of neck. In young specimens the upper parts and the breast are grayish brown and buff. The body is about nine inches long.

Nests in the Arctic regions; in South Dakota only during migration. 
FAMILY ODONTOPHORID.E. BOBWHITES, QUAILS; FAMILY TETRAONID王. GROUSE

These families include such well known birds as our Prairie Chicken, Prairie Sharp-tailed Grouse and Bobwhite or Quail. They are of great economic value, not only as excellent game birds, but because during the summer months a very large part of their food consists of injurious insects.

Quails or Bobwhites followed the farmer westward. The first record of these birds in the State, as far as known, was in 1872 when Dr. Elliott Coues, the noted ornithologist, took specimens at Fort Randall. They are non-migratory, and many perish if caught in severe snowstorms without artificial feeding and protection. Whole coveys have been found frozen or starver to death upon the melting of snow in spring. In summer they feed on insects, and ustally upon those that are injurious to crops, such as grasshoppers, chinch bugs, crickets, etc.

Prairie Chickens, which were formerly native to the Mississippi Valley States farther south, also fullowed the farmer into the northern prairie States, where they were very abundant until a few years ago. They are rather scarce today, because the land has become thickly settled and they have been persistently hunted.

After the grain is cut they resort to stubble fields, where they feed on insects and the fruit and leaves of the wild rose. Very little grain is eaten until winter. When the ground is covered with snow they resort to corn fields, where they eat only a portion of the extra corn that the farmer has been permitted to raise because they reduce injurious insects to the minimum.

On December 27, 1915, the crop and stomach of a Prairic (hicken was examined and the contents consisted of timothy and red clover leaves and a few weed seed, but not a single kernel of grain was found. There was no snow on the ground. The same week the crop and stomach of a Ring-necked Pheasant taken in the same locality was examined and the following found: 132 kernels of corn, twenty-five kernels of oats, and a few seeds each of wild sunflower, pigeon grass, and smartweed.

Although Prairie Chickens gather in flocks in the fall, 
they migrate only a few miles, perhaps to find more suitable feeding grounds.

The Prairie Sharp-tailed Grouse once inhabited the whole State, but they do not take kindly to civilization. At present they live in open thickets along the Missouri River and westward in the Black Hills. Their numbers have been greatly depleted by incoming settlers, but in the future they will probably hold their own as they are wary birds and will select the most secluded areas for breeding grounds. In summer they live largely on insects, while in winter they depend mostly on weed seeds and berries. During deep snows they occasionally resort to corn fields for a meal.

The Ruffed Grouse is probably found within the State only in the Black Hills, although one may occasionally be found on the west shore of Big Stone Lake, across from Minnesota. In the latter case it would be the eastern species or "red phase," while the native of the Black Hills is the western species or "gray phase." Its natural haunts are wooded hillsides and deep ravines, where it feeds on insects, buds and wild berries. These beautiful birds are not abundant and will in time become quite rare, as they are continually hunted for sport and food. However, under present conditions the Ruffed Grouse will probably be the last of our game birds to become extinct.

All members of the Grouse family are highly favored with protective coloration. This is especially noticeable in the two species of Ruffed Grouse. The plumage of the eastern form or "red phase," has the tinge of reddish autumn leaves, while that of the western or "gray phase" in the Black Hills has the tinge of dead gray pine needles. In their natural haunts it is almost impossible to see either bird before it is flushed, so nearly do they match the background of their native woods.

The Grouse family must be protected and allowed to increase in South Dakota. Upon the Prairie Chicken, Quail and Grouse we must depend for assistance in keeping down the ever increasing number of injurious insects, such as grasshoppers, crickets, chinch bugs, army and wire worms, and beetles. Years ago Shore Birds were abundant in South Dakota and lived on these insects, thus helping to balance nature; but Shore Birds have been forced from the State, never to return, because their 
natural haunts have been destroyed by the drainage and cultivation of all the wild land. Prairie Chickens, Quail and Grouse constitute the only big family of birds that can take their place in successfully keeping down insects.

Our game laws are adequate but sadly disregarded by a large portion of our population.

\section{Bовwhite (Colinus virginianus virginianus.)}

The "Quail" is one of our most valuable and best known birds. However, it is shy and said to be very difficult of domestication; yet it is never found far away from civilization. It is now found over the State except, perhaps, in the northwestern part; but it is not abundant and never will be unless given more protection. It is not a migratory bird, seldom moving a mile from where it was raised; it is therefore placed at the mercy of our severe winters with their deep snow. During the fall low rude pole sheds should be erected in thickets and covered with straw or fodder to afford protection: they should be quite large and banked on two sides, so that snow will not fill them completely. In these sheds a few handfuls of grain should be scattered often enough to attract the birds and keep them familiar with the surroundings. They should also be fed now and then during deep snow. When there is little or no snow they have no trouble in securing weed seeds, of which each "Quail" will devour many pounds during a winter season. In the summer their food consists principally of insects, hence we can readily see that they are continually working for the farmer and that he can well afford to offer the little fellows the small protection and food that are necessary to help through the severe snow storms.

The Bobwhite is about nine inches in length. In the male the throat, forehead and line over eye are white, bordered with black; while in the female these white markings around the head are buffy or dull. The body is brownish red mixed with white and black.

297. Dusky Grouse (Dendragapus obscurus obscurus.) "FOOL HEN."

This Grouse is rare in South Dakota, but a few may be seen in or near the Black Hills. It is one of the largest of our 
Grouse, measuring in length from eighteen to twenty inches. The back of the male is dark slate mixed with brown and gray; below it is light slate. The tail is dark slate fully barred on the back. Like all true Grouse it is feathered on the legs, but not so persistently as the Sharp-tailed Grouse. The Dusky Grouse is a bird of the mountains, usually found in the evergreen zone. It feeds on berries and insects.

300b. Gray ruffed Grouse (Bonasa umbellus umbelloides.)

An annual resident and rather abundant in the Black Hills. This is the Partridge or Pheasant of wooded areas east $o^{\prime}$ Minnesota and the Mississippi River, except that its general color is grayish instead of mixed rusty brown. About seventeen inches long; head slightly crested with gray; body gray, mixed with rufous and black; tail mixed gray with a wide slate colored band near the tip. Both male and female have back neck tufts, hence the name.

The male produces his drumming sound by rapidly beating his wings, usually while perched on a log. They are frequently found in deep woods feeding on berries, buds and insects.

\section{Pratrie Chicken (Tympanuchus americanus americanus.)}

The male is eighteen inches in length; female slightly smaller; alike in color; irregularly barred with black and rufous, with some white on wings and tail; under parts barred with white, dark brown and buff; front and side of legs covered with short, downy feathers; head slightly crested. On the sides of the neck there are tufts of feathers, which, when extended, resemble small wings. These tufts cover a yellow, bare sac that is capable of being expanded by the male to the size of a small lemon. The function of this inflated sac is perhaps not definitely known but it is thought to connect by a canal with the windpipe and thus assist in producing that "booming" sound which is so often heard, especially during the early spring.

Their nesting place is usually in meadows, but an unplowed strip of wild hay land is sometimes preferred.

A closed hunting season for a few years, and the creating of public sentiment for law enforcement, are much needed to increase Prairie Chickens in sufficient numbers to make them of cconomic importance, either as game birds or insect destroyers. 


\section{8b. Prairie Sharp-tailed Grouse (Pedioecetes phasianellus campestris.)}

This Grouse is slightly smaller than the Prairie Chicken, though similar in color. It has more white on wings and under parts, and V-shaped instead of bar-shaped markings. It has a small head crest, but no neck tufts. The tail narrows to a sharp point, and the legs are more heavily feathered than in the Prairie Chicken.

Its nesting places are open thickets and grassy flats along the Missouri River and westward. Late in the fall several coveys may flock together and migrate a short distance, perhaps for more favorable feeding grounds. It should, however, be classed as one of our resident birds.

309. SAGE HeN (Centrocercus urophasianus.)

The largest of our Grouse, the males measuring up to twenty-nine inches and the females to twenty-two. The sexes do not differ much in color. Back variegated with black, white and buff ; under parts whitish with black areas; long tail feathers of the male pointed, having the appearance of being worn off; legs feathered.

They formerly inhabited the whole western half of the State, but are now limited in range to Fall River, Butte and Harding counties. They are usually found in sagebrush regions and feed on sage buds and insects, the latter principally grasshoppers. Their nesting places are usually under or near a clump of sagebrush, or along sparsely grass covered creek flats.

They are not eagerly sought after by hunters, as the flesh has a rather strong sage taste.

\section{Ring-NeCKed Pheasant (Phasianus torquatus.)}

This bird was originally from China and is known in some localities as the Chinese Pheasant. It has, however, been crossed with the English Pheasant, Phasianus colchius, and specimens without the white neck ring are hybrids.

This beautiful Pheasant was introduced into South Dakota several years ago and is living in a semi-wild state. In some localities it is said to be increasing rapidly; but it is perhaps too early to say whether or not it is really a valuable addition to our list of game birds. 


\section{FAMILY MELEAGRID压. TURKEYS}

310a. Wild TURKeY (Meleagris gallopavo silvestris.)

There are no Wild Turkeys in South Dakota today, but until about 1875 they were frequently hunted for food by the early settlers in Union and Clay counties. In the diary of Captain Lewis, of the Lewis and Clark expedition, of date September 5, 1804, it is stated that, at a point up the Missouri River 145 miles from the mouth of the Sioux, their hunters brought in among other game "some wild turkeys." The diary also states that " 3 wild turkeys were secured" at a point just above the present site of old Fort Randall.

The Wild Turkey is about the size of the common Turkey but of a uniform color, the plumage being a rusty black with the rump and tail feathers a reddish brown, while the larger wing feathers are grayish.

Today the Wild Turkey is nearly extinct in the United States and it is doubtful if many of the present generation will ever see a specimen of the ancestor of our domestic Turkey, which is so much appreciated at our Thanksgiving dinners.

\section{FAMILY COLUMBID压.PIGEONS}

\section{Passenger Pigeon, Wild Pigeon (Ectopistes migratorius.)}

While the range of the Passenger Pigeon was usually farther east, old South Dakota settlers reported its occurrence quite frequently in our southeastern tier of counties.

It can perhaps be said that for one hundred years the Passenger Pigeon was one of the most abundant birds in the eastern half of North America. Their numbers in migration could be compared to those of migrating buffaloes on the western plains. It would take hours for either a flock of Pigeons or a herd of buffaloes to pass a given point. A flock of Pigeons would, for a time, shut off the sun's rays, while a massive herd of buffaloes would often prevent the movement of trains on the frontier until the great mass had passed over the track. But the fate of the buffalo is the counterpart of that of the Pigeon.

One of the writers saw Passenger Pigeons in abundance in Illinois in the early seventies, but in describing them at this 
date memory only recalls that in general appearance they very much resembled our Mourning Dove, except that the Pigeon was a third larger. It is also likely that the head of the Pigeon was slaty while that of the Dove is buffy. Their food consisted of acorns, berries, weed seeds and grain. They were gregarious in nesting habits, building slight nests of fine twigs and laying one or two white eggs, which were somewhat larger than those of the Mourning Dove.

316. 1. Western Molrning Dove (Zenaidura macroura marginella.)

A common bird over the entire State. It comes early in: the spring and remains till late autumn. Specimens have been. seen in Clay County even in January. This Dove is about eleven inches in length. The forehead and sides of head are buff; top of head and back slate or slaty brown. The male has under parts of buff with iridescent neck feathers, while the female is paler, with breast more grayish brown.

The very slight nest is placed in low trees, or sometimes. on the ground. They frequently use old nests of other birds, but always place a few weed stems in the old nests for their eggs and young to rest upon. Their principal diet is weed seeds, of which they devour vast quantities, as many as 9,200 having been found in a single bird's stomach. 


\section{RAPTORES}

The Raptores are divided into six families, which include the Vultures, Eagles, Hawks and Owls, etc. About thirty-five species of these families are represented in South Dakota. Most of them are summer residents: the Great Horned and Screech Owls and Eagles are annual residents: the Snowy Owl and the Goshawk are winter residents, and individuals of other species may occasionally spend a winter in the State.

Perhaps no other class of birds is of greater economic value to our agricultural interests, although none is less appreciated. Of the thirty-five species, at least thirty are working day or night to keep down the great armies of mice, gophers and larger insects, such as grasshoppers and crickets, which destroy millions of dollars worth of crops every year. And yet the average citizen seems proud of positive knowledge, as he thinks, that every Hawk and Owl lives especially to feed upon his poultry. Many of our boys are given guns and allowed to destroy innocent life, perhaps even ordered by their parents to "kill every Hawk in sight." This is the reason that our socalled sportsmen, while hunting, slay every Hawk and Owl that cross their paths. Will we ever be educated up to the point where public sentiment is against this everlasting murder, murder, murder of innocent life?

Sufficient investigations and examination of the contents of stomachs of these birds at different seasons have been made by the Biological Survey, Department of Igriculture, to justify them in making authoritative statements as to the character of Hawks and Owls in the United States. Every Hawk or Owl of South Dakota, whether resident or migratory, will be described in this bulletin to further aid the public in identifying the species that should be protected.

\section{FAMILY CATHARTIDE. AMERICAN VULTURES}

325. Turkey Vulture: Turkey Buzzard (Cathartes aura septentrionalis.)

These large birds are frequently seen during the summer along the Missouri River and over the western half of the State, especially in the bad lands. They have been known to nest in 
Harding County, which is the northwestern corner county of the State.

Length about thirty inches; head and neck bare, with red skin; balance of body brownish black, except under wings and tail, where it is grayish.

Their food consists entirely of carrion, so that they are of inestimable value as scavengers.

Farther south they usually nest in hollow logs, but in our State they use shelves under overhanging cliffs in the badlands. Eggs usually two, white, and somewhat larger than that of the domestic Chicken.

One noticeable characteristic in the flight of this bird is its ability to sail or soar for hours with very few wing movements.

\section{Black Vulture (Catharista urubu.)}

Sometimes called Carrion Crow. This Vulture is a rare straggler during the summer in South Dakota. Although somewhat shorter than the preceding it is heavier in weight. Head and neck bare, with black skin; balance of body black.

\section{FAMILY BUTEONIDA. KITES, HAWKS, EAGLES}

\section{Swallow-tailed Kite (Elanoides forficatus.)}

A rare visitor in our State during the summer months. Length about twenty-four inches, but the long, forked tail comprises over half; head, neck and under parts white; back, wings and tail bluish black. Their food consists of large insects and snakes.

\section{Marsh Hawk (Circus hudsonius.)}

A very common Hawk and well distributed over the State. The male is about twenty inches long; above, bluish gray, with the ends of the long wings much darker; throat and breast ashy gray; belly white; tail usually with seven dark bands. Female about twenty-two inches long; above, dark brown, sometimes mixed with cinnamon or whitish spots; under parts whitish streaked with brown. The young resemble the female but are usually darker. A distinguishing mark of the Marsh Hawk is its white rump, plainly seen as the bird flies 
over meadows and weed fields in search of small rodents. In proportion to its size the wings and tail are longer than in other Hawks. The nest is always placed on the ground in tall grass or buck-brush thickets. This Hawk should never be killed, and everyone, farmers in particular, should become familiar with it and aid in its protection. Mice and gophers comprise the bulk of its food. Of 124 stomachs examied by the Biological Survey, Department of Agriculture, forty-five per cent had fed on mice, eighteen per cent on other small mammals, twenty-eight per cent on reptiles, frogs and insects, and only a low percentage on poultry and small birds. In 1910 a pair nested within thirty rods of a farm house in Perkins County. Their family consisted of five young, and as far as known not a single member of the poultry yard was molested.

One should not be surprised if the young birds, while beginning to feed themselves, and with that ravenous appetite which all young creatures have, should sometimes take a young Chicken. This might be clone occasionally in the immediate neighborhood of their nest, when the fields have been searched for mice and gophers during the summer by the parent Hawks. However, the harm they do is negligible compared with the vast amount they save the farmers each season.

\section{Sharp-shinned Hawk (Accipiter velox.)}

One of our smaller Hawks, measuring only from eleven to thirteen inches in length, and not as common as the Marsh Hawk. The female is longer than the male but the extra length of her tail makes the difference. Back dark slate; head and neck usually more or less streaked with brown and white; under parts including wings barred with white and rufous; tail with four bars. Of the stomachs examined by the Biological Survey, Department of Agriculture, ninety-four per cent of the contents showed small birds and young poultry. This Hawk should be destroyed with the same care that we use in protecting the Marsh Hawk. But no Hawk should ever be killed until one is sure what species he is killing. The destructive Hawks are the exception, the beneficial ones the rule.

333. CoOper's Hawk (Accipiter cooperi.) "Chicken Hawk." This Hawk is found quite generally over the State. Its 
plumage is similar to that of the last, but the bird is larger, measuring from fifteen to nineteen inches. The female is longer than the male but the difference, as in the Sharp-shinned is in the extra length of tail.

The food of this Hawk is about the same as that of the Sharp-shinned, and the bird should be persecuted with the same earnestness. Being larger than the Sharp-shinned it will probably destroy more poultry.

\section{Goshawk (Astur atricapillus atricapillus.) "Hen Hawk."}

This Hawk usually nests in the northern part of North America and is regarded as only a winter visitor, although it probably nests sometimes in our State. Length from twenty to twenty-four inches; female slightly larger; back bluish gray; crown and area back of eyes black; white line over eyes; under parts white, irregularly finely barred with gray, and with occasional black streaks extending lengthwise; tail with four or five blackish bars.

If this Hawk were a summer resident it would probably be the most destructive of all Hawks to poultry, as, on account of its large size, it is capable of carrying away full-grown hens. It also destroys many game birds such as Quail, Grouse and Prairie Chickens. It therefore comes in the list of harmful Hawks and should be killed.

337. Red-TAILed HAwk (Buteo borealis borealis.)

A rather common Hawk over most of the State during the nesting season; twenty to twenty-five inches in length, the female larger; tail usually reddish brown, tipped with white and a subterminal black band, although occasionally one will be seen with several narrow black bars on the tail. Above, blackish brown, the brown-tipped crown feathers showing white when raised. Under parts whitish, usually with a dark area across the belly. In the young the upper tail surface is often grayish with several darker bars. The plumage of the Red-tailed Hawks varies in color so that it is impossible to give a description that will apply to all individuals.

This Hawk is heavier than the preceding species although its length is the same, and it is not so agile in flight. Examination of many stomachs reveals the fact that it lives on snakes, mice and other small rodents and should be protected. 


\section{7a. KRIDER's HAWK (Buteo borealis krideri.)}

The Krider Hawk is a subspecies of the Red-tail and similiar but lighter in plumage, being nearly white on the under parts. It is of the same size and has the same feeding and nesting habits. A few specimens have been taken in our State.

\section{Red-Shouldered Hawk (Buteo lineatus lineatus.)}

As far as we know this Hawk is rare in South Dakota, its principal range being east of us.

Among specimens taken in this range the male is about twenty inches in length and the female twenty-two. Farther south they are smaller. Above, dark reddish brown, shading to rich brown on wings; head, neck, and under parts rufous, more or less streaked with light and dark; tail with several light narrow bands, and tipped with white. Young usually darker above and lighter below.

Its feeding and nesting habits are much the same as those of the preceding species and it should therefore be protected.

\section{Swainson's Hawk (Buteo sziainsoni.)}

In abundance this Hawk ranks next to the Marsh Hawk in our State, being rather more common west of the Missouri River, where it nests in cottonwood trees along wooded creeks.

In size it is about the same as the Red-shouldered, viz., twenty to twenty-two inches. Swainson's Hawk has such a wide variation in plumage that any description must be of only general application. Adults, on the back, usually plain sooty brown; throat nearly white, with under parts buff or tawny, blotched with brown of the same shade as the back; flanks usually barred; under tail dark slate crossed with several zigzag black bars; a wider band near the tip. The young are usually much darker, many specimens running to plain soot brown both above and below, sometimes showing a rufous tinge and bars on the flanks.

These Hawks are said to nest on the ground and on cliffs as well as in trees. Like many of our larger species they will at times take possession of a last year's Crow's nest. 'Their food consists of mice, gophers, large grasshoppers and crickets. 


\section{BROAD-WINGED HAWK (Buteo platypterus.)}

This bird is only fairly common in South. Dakota. Its range is farther east. Size fifteen to eighteen inches, the female larger. Lpper parts dark brown; feathers on nape white at base; under parts irregularly barred with white and buff; under tail with two white bands and a white tip. The young are usually much darker both above and below. The belly is not barred but is streaked with blackish brown and tawny. On September 25, 1915, a young specimen was sent to the University Museum and, upon examination, the crop and stomach showed the following contents: thirteen large grasshoppers, two field mice, and one frog. These would be sufficient food for this Hawk for not more than one day. A similar supply would be used daily throughout August and September, when mice and grasshoppers are most destructive to ripening crops. The Hawks are each worth fifteen dollars annually to the farmers of South Dakota because they devour mice and grasshoppers that would destroy crops of that vlaue.

347a. RoUGH-LEGGED HAwK (Archibuteo lagopus sancti-johannis.)

This Hawk nests north of the United States and comes to us as a spring and fall migrant.

The male is about twenty, and the female about twentytwo inches in length. On account of its remarkable variation in plumage the bird is difficult of description. The fact that it is feathered to the toes, however, easily distinguishes it from any Hawk thus far listed from South Dakota. The back and upper wing feathers are usually dark slaty hlack, mingled with reddish brown or buff, the head and hind neck being lighter. The under parts are buff mixed with black, except that on the lower belly there is usually a very dark area. The under tail is nearly white with a black band near the tip. The young average darker than the adults.

Its diet of mice, gophers, grasshoppers, frogs and snakes easily places it in the protective list.

\section{Ferruginous Rough-LEG (Anchib:teo fermoninets.)}

This Hawk is slightly larger than the preceding, measuring from twenty-two to twenty-five inches in length, the female being the larger. Like the Rough-legeed Hawk, it is feathered 
to the toes. Under parts usually white the entire length; leg feathers barred with brown; back and upper wing feathers reddish brown streaked with black; head and neck streaked with black and white. The young are much darker.

These birds are not abundant in South Dakota, and they should never be killed, as they are very destructive of small rodents and large insects.

\section{Golden Eagle (Aquila chrysaetos.)}

This Eagle is quite common in western South Dakota though rare in the eastern part of the State during the winter. It nests in the badlands and forest reserves. Length about three feet; plumage dark brown more or less mixed with light brown; head and back of neck grayish; under side of wings and tail with white spots, which increase in extent with age.

The nest, which is built of sticks, is usually a bulky affair, and is sometimes placed on a rock ledge or in a high tree. The same pair will use the old nest with slight repairing year after year.

Eagles live on rodents, game birds, and even lambs. When they become too numerous in a neighborhood they must be classed as destructive.

Among the North American Indians the tail feathers of the Golden Eagle have always been considered a symbol of power, either in war or the chase, consequently they have been in great demand. ()ne pony, or more if the feathers were nearly white, was the price for a set of twelve.

The Sioux Indians adopted a unique method of capturing the Eagle. A pit was dug large enough for a brave to secrete himself in. This was covered over with brush and grass to resemble the surrounding surface and a bait placed on the covering. When the Eagle alighted for his meal he was captured by the occupant of the pit clutching his legs. Many are now caught during the winter in the western part of the State in steel traps set for wolves and coyotes.

\section{BALD EAGLE (Halincetus leucocephalus leucocephalus.)}

The Bald Eagle rarely nests in South Dakota, but is frequently seen during the winter months. It is slightly smaller than the Golden Eagle and the adults are easily distinguished 
from the latter by the white head, neck and tail. The balance of the body is dark brown, and the legs bare. During the first year the young are nearly black, including the head; the second year they are gray, and not until the third year do they take on the plumage of the adults. Their nesting and feeding habits are similar to those of the Golden Eagle.

The Bald Eagle is used as our national emblem, and is represented on our different coins.

During the Civil War the 8 th Wisconsin Regiment carried a Bald Eagle as a mascot. It was known as "Old Abe," and became a noted bird, being exhibited at Philadelphia during the Centennial in 1876. Later its body was preserved in the State capitol at Madison.

354. Gray Gyrfalcon (Falco rusticolus rusticolus.)

A rare winter visitor in South Dakota; breeds in the Arctic regions. Twenty to twenty-four inches in length, female the larger. Above, brownish gray. Lnder parts streaked with gray and white. Legs feathered to the toes. The pair in the University Museum were taken in Miner County.

355. Prairie Falcon (Falco mexicanus.)

A rather common bird in our State west of the Missouri River, nesting frequently on shelving cliffs in the badlands.

It is about eighteen to twenty inches in length, the female being the larger. The sexes are similar in plumage, being brownish gray on the back and lighter on head and neck. The under parts are white with dark brown streaks on throat and breast. The young are marked with rufous above and brown buff below. Unlike true Hawks, the Falcons have a toothed beak.

356a. Duck Hawk (Falco peregrinus anatum.)

This Hawk is frequently seen in the State, though it is not common. It is about the size of No. 355 but has longer toes. Its peculiar characteristic is black spots on the sides of the throat. Back, wings and tail are bluish slate with irregular dark gray bars. Below, buff with black markings running to bars on the flanks and extreme lower parts.

On account of its great strength much of its food consists of game birds and if abundant it would be considered destructive. 


\section{Pigeon Hawk (Falco columbarius columbarius.)}

Probably seen only in migration in South Dakota. From eleven to twelve inches in length. Male above bluish slate; throat usually nearly white; belly light but streaked with brown; tail with four dark bands, the wide end one tipped with white. Female and young, dark brown above; below buffy and more heavily streaked with brown; tail with four or five bands.

357b. Richardson's Pigeon HaWk (Falco columbarius richardsoni.)

This Hawk is not common in the State but probably nests occasionally. In size and plumage it clearly resembles No. 257 but is more of a grayish drab in color, and usually has six bands on the tail.

\section{Sparrow Hawk (Falco sparverius sparverius.)}

Abundant over the entire State, nesting in old Woodpecker holes, hollow trees, and crevices in the badlands. The smallest of our Hawks, measuring not over ten or eleven inches in length. The crown of both sexes is bluish slate, usually with a chestnut patch. Male: back and tail chestnut with a few black bars on back and one wide black bar on tail; wing coverts bluish slate; under parts creamy white with black spots. Female: chestnut brown above, with many blackish bars on back and tail; below whitish, streaked with brown. Its food is chiefly mice, grasshoppers, beetles, and occasionally small birds.

\section{6t. Osprey; Fish Hawk (Pandion haliaetus carolinensis.)}

Rather rare in South Dakota. Crown white streaked with black; throat and breast white or streaked with brown; black line on sides of neck reaching to eyes. Under parts white; back black or blotched with white and brown; legs longer than in Hawks; toes open to the base; claws of equal length. The plumage is close and oily, which fits it for diving after fish, its principal food.

\section{Barn Owl (Aluco pratincola.)}

This Owl has been rarely taken except in the southern part of South Dakota. Length about eighteen inches; above, buff mixed with gray; below, white and tawny usually with small black spots; no ear tufts; eyes black; face disk almost a 
complete circle and darkly bordered. Its chief food is mice, which makes it highly valuable from an economic standpoint.

In the summer of 1919 a number of these Owls were seen during day time hiding in cavities of the red brown limestone bluffs along the Missouri River near Springfield. The reddish gray plumage of the Owl was so nearly the color of the "red chalk rock" that the protective coloration was almost perfect.

\section{LONG-EARED OwL (Asio wilsonianus.)}

Common over the entire State, nesting in trees along wooded rivers and creeks. About fourteen inches in length; below, buff, usually streaked and crossbarred with brownish black; long ear tufts and yellow eyes. These birds are invaluable to the farmer, as their food consists almost entirely of injurious rodents.

\section{ShORT-EAREd Owl (Asio flammeus.)}

Length fifteen to sixteen inches; ear tufts short; above, black and brown, each feather having a blackish center margined with brown; below; lighter and streaked with brown; never barred. The plumage of the female is usually slightly darker than that of the male.

This is almost exclusively a prairie Owl. It hunts for mice and other small rodents over our prairies and marshes, and nests on the ground in a clump of weeds or tall grass. It is found over the entire State, and should never be killed, but protected and encouraged to increase in numbers.

368. BARRED OwL (Strix varia varia.)

A summer resident but rare in South Dakota, its range being in the eastern United States.

Length twenty inches; general appearance tawny, with back, head and breast barred with white; belly lighter but with blackish streaks; no ear tufts; eyes black; toes feathered nearly to the nails.

370. Great Gray Owl (Scotiaptex nebulosa nebulosa.)

This Owl breeds in the far north. As far as we know there is no record of its having been taken in the State, except that Dr. Elliott Coues reports it as "straying south in winter 
to Dakota, etc." Mr. Rudolph M. Anderson in "The Birds of Iowa" reports it as "a casual straggler in winter."

It is the largest of North American Owls, measuring two feet or more in length. Upper parts dark brown mixed with grayish white. Under parts the same in color, with irregular bars but paler. Prominent facial disk with small eyes. No ear tufts; legs and feet feathered. It inhabits wooded regions.

371. Richardson's OWl (Cryptoglaux funerea richardsoni.)

A rare winter resident in our State. Length ten inches; no ear tufts; above, brown with white spots; below, white streaked with brown; feet feathered to the toes. Nests north of the United States in hollow trees.

\section{SAW-whet OWL (Cryptoglaux acadica acadica.)}

The smallest of our Owls, averaging only about eight inches in length. Back, wings and tail uniform dull brown spotted with white; crown streaked with white; under parts white and brown; facial disk nearly white; toes feathered.

This Owl inhabits wooded districts and nests in hollow trees or old Woodpecker holes. Owing to its hainit of retiring into dark woods it probably is not often observed. In some instances it may be taken for the Screech Owl.

373. Screech Owl (Otus asio asio.)

Screech Owls are common over the state and are permanent residents, spending their lives in the vicinity where they are raised. They are larger than the Saw-whet Owl, measuring nine to ten inches in length. Unlike other species of Owls in our State, the Screech Owl has two color phases, gray and red. We quote Mr. Frank M. Chapman's description: "With ear tufts; eyes yellow. Adults, gray phase: above, buffy gray irregularly marked with black; below, gray, white, rusty and black. Adults, red phase: above, bright rusty brown with a few black streaks; below, white streaked with black and barred with rusty brown. Young: above, gray or rusty barred with black and white; below, white thickly barred with blackish." The two-color phases may develop in individuals of the same nest. Some writers contend that the same individuals may pass from one phase to the other independently of sex, season or locality. 
According to the writers' observation the "gray phase" predominates in South Dakota, while records from eastern Iowa seem to show the reverse.

The Screech Owl may be found at home along wooded creeks in the most sparsely settled districts, or in resident portions of our larger towns and cities. In the latter case they no doubt help to keep down the increasing numbers of "pesky" English sparrows. Their food consists chiefly of mice. They should be encouraged to nest around buildings. Their weird, wailing notes, heard at dusk or in early morning, have caused some who are not acquainted with the call notes of these little fellows to suspect that a strange wild cat was prowling in the vicinity.

373e. Rocky Mountain Screech Owl (Otus asio maxwelliae.)

Specimen taken in Fall River County, August 8, 1911, by Stephen S. Visher and determined by H. C. Oberholser of United States Biological Survey as this species.

Resembles the common gray Screech Owl but paler; black markings not so prominent.

375. Great Horned Owl (Bubo virginianus virginianus.)

Common over the State and more or less resident. One of our largest Owls, measuring up to twenty-two inches in length, the female always larger.

The Great Horned Owl is quite variable in color markings. Above their base the feathers are tawny, sometimes tawny and gray, but more or less irregularly tipped with black and white. Below, usually lighter, mixed with tawny, and occasionally there are black spots on the breast and a white throat. Tail barred with black; long ear tufts.

They nest in hollow trees or nests used by Crows the previous season. The eggs are laid as early as February or March. On April 1, 1919, two weeks old young were taken from an old Crow's nest near the Vermillion River in Clay County.

Great Horned Owls catch and eat a variety of animals ranging in size from small birds and mice to cottontail rabbits or full grown poultry. In some instances they have been known to kill more poultry than was necessary to satisfy their hunger. This is probably true only of certain individuals, and a good way 
to dispose of these is to keep a steel trap set on a small platform erected at the top of a pole located near the poultry house. It is evident that where these Owls become too numerous in a neighborhood they must be classed as destructive.

375a. Western Horned Owl (Bubo virginianus pallescens.)

This is a variety of the Great Horned Owl said to be found in South Dakota. It is described as smaller and paler than No. 375. One of the authors in examining many specimens from over the State, has been unable to detect any form which was more than a variation in plumage of the Great Horned Owl.

375b. Arctic Horned Owl (Bubo virginianus subarcticus.)

Another variety of the Great Horned Owl, very similar in size but lighter in plumage, varying from gray to nearly white, mixed with tawny and black. At a distance it resembles the Snowy Owl but is easily distinguished by its long ear tufts. As the name implies, its habitat is in the Arctic regions, where it breeds. Only occasionally during the winter an individual straggles as far south as our State.

A specimen was taken by Mr. F. A. Patton, of Artesian, in Sanborn County, in January, 1895.

376. Snowy OwL (Nyctea nyctea.)

About the same size as the Great Horned Owl. It breeds in the Arctic regions and migrates irregularly to South Dakota during the winter. In plumage it varies from pure white to mixed white and brownish black. A pure white specimen is rare, the common markings being white barred with brownish black, the female usually darker. They are without ear tufts and the feet are almost completely feathered. Since their food consists chiefly of mice and other small rodents, they are of great economic value to our agricultural interests.

The Snowy Owl seems to be more abundant some winters than others, and it is believed that an early winter with continuous cold is favorable to their southern migration. During the severe winter of $1917-18$ at least a dozen were taken in the State, while during the mild winter of 1918-19 only a single specimen was reported. Such a beautiful bird should never be killed. 



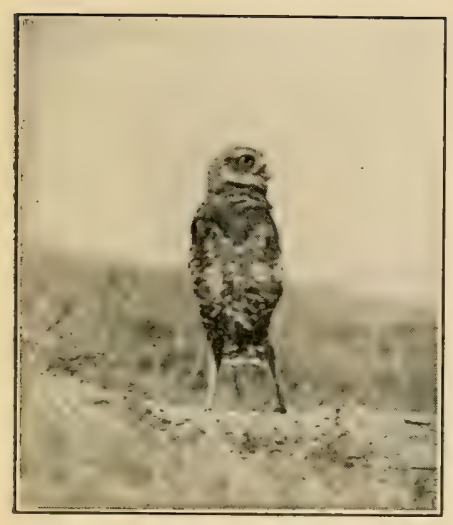

BURROWING OWL BY HER NEST

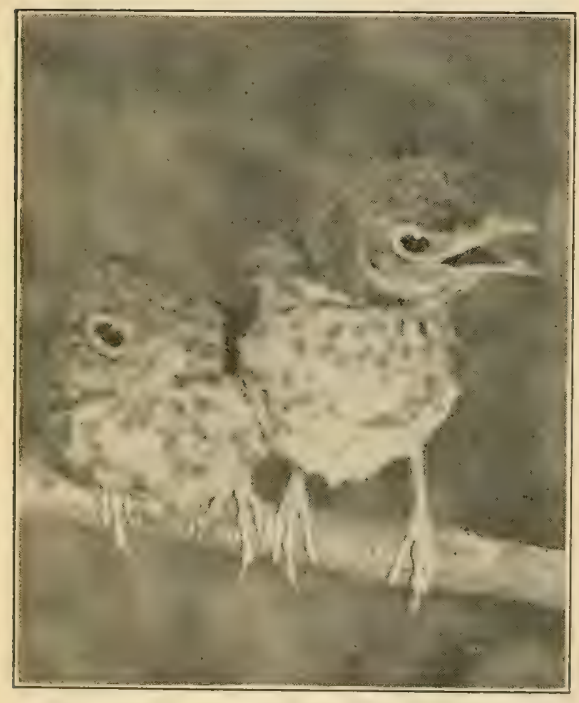

YOUNG WOOD THRUSHES

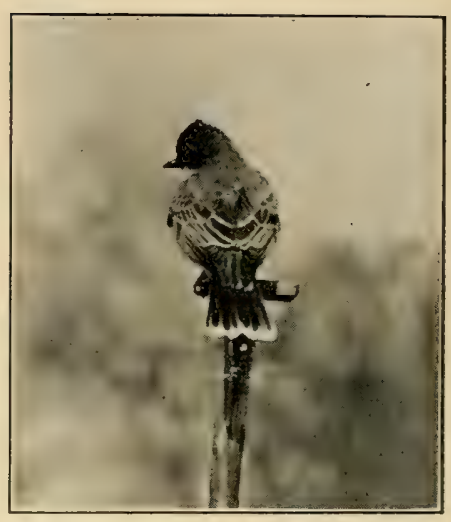

KINGBIRD WATCHING FOR FLIES

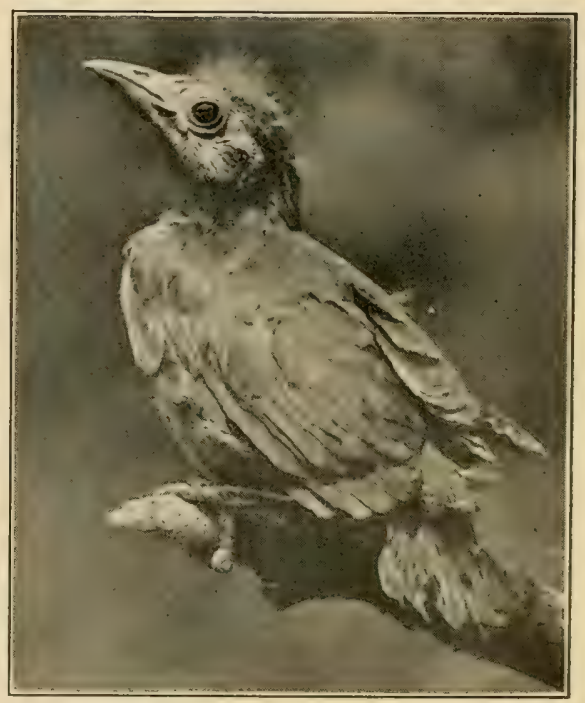

YOUNG BRONZED GRACKLE 


\section{Burrowing Owl (Speotyto cunicularia hypogaea.)}

This little Owl is a common summer resident over the State, but most abundant west of the Missouri River. Length from nine to ten inches; above dull grayish brown spotted with white; white throat patch crossed by dusky band; belly light but barred with brown; legs much longer than with other South Dakota Owls and feathered in front but bare behind. This bird also differs from other Owls in its habits of nesting. Instead of building in trees or on the ground, it appropriates the abandoned hole of some burrowing animal. East of the Missouri River it occupies the holes of skunks, badgers or foxes; west of the river it usually takes possession of deserted prairie dog holes. It does not, however, live in common with prairie dogs and rattlesnakes, as many suppose. In every prairie dog town there are many unoccupied holes. These offer convenient nesting places for the little Owls. The food of the Burrowing Owl consists mostly of small rodents, grasshoppers and bettles.

\section{FAMILY CUCULID瓜. CUCKOOS}

The Cuckoos or "Rain Crows" are beautiful velvety olive brown birds with rather short wings and long tails. They are about the size of the Brown Thrasher and much the same in form. Their "cow, cow" notes are heard oftener than the birds are seen, as they love dense shade and keep well within the foliage of trees and bushes. They devour vast numbers of hairy caterpillars, of which they are especially fond, a single stomach sometimes containing as many as 250 .

387. Yellow-Billed Cuckoo (Coccyzus americanus americanus.)

The lower bill is more yellow than in the following species, and the white patches on the tail feathers much larger. It prefers nesting in trees rather than in bushes. A summer resident.

\section{Black-Billed Cuckoo (Coccyzus erythrophthalmus.)}

This species is more plentiful in the State than the preceding. It prefers nesting in bushes rather than in trees. There are only slight traces of yellow at the base of the black bill, and the tail lacks the strong contrasts of white and black. A summer resident. 


\section{FAMILY ALCEDINIDÆ. KINGFISHERS}

Kingfishers, as the name implies, are fishers and are usually seen flying or perched above the water. Their sole diet seems to consist of fish.

390. Belted Kingfisher (Ceryle alcyon.)

It is about twelve inches in length, including a long, stout bill. The bushy crest and back are bluish gray; belly white or marked with rusty.

The chief characteristics are the white throat and neck bands. The male has a bluish gray breast band, which in the female is rusty.

The Kingfisher, though not very abundant, is found in every State in the Union. Every stream, millpond and wooded lake shore is wakened by its rattling notes as it plunges in headlong flight from one dead limb perch to another. It lives entirely on small fish, which it takes by plunging into the water. Its nest is the enlarged end of a hole, sometimes eight or ten feet long, which it tunnels into some high bank. A summer resident.

\section{FAMILY PICIDE。 WOODPECKERS}

South Dakota has a number of the choicest of this family. Theirs is the difficult task of chiseling through the bark to extract wood borers that would destroy our trees. They also feed upon the insect eggs, larvae and cocoons found in bark crevices. They excavate nest holes in dead trees, and in the autumn some of them excavate winter homes. When these excavations have been used by them they become the natural nesting places of Wrens, Bluebirds and Chickadees. At one time the idea was prevalent that Woodpeckers usually constructed their nest holes so that the entrance was toward the northeast or east, but a careful survey made by one of the writers along the Missouri River in 1919 of over 70 holes would tend to disprove the statement, as 20 opened to the west, 17 to the north, 10 to the south, while 6 opened to the northeast, and 2 to the east.

The toes of Woodpeckers are arranged differently from those of most other birds, two being in front and two behind, which with their long nails enable them to cling to bark while climbing. They are also supported in climbing by their stiff tail feathers. 



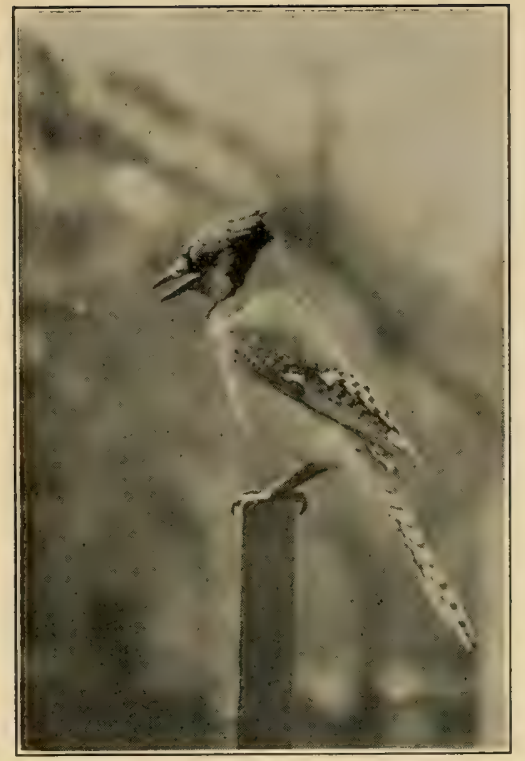

BLUE JAY

WATCHING FOR INSECTS

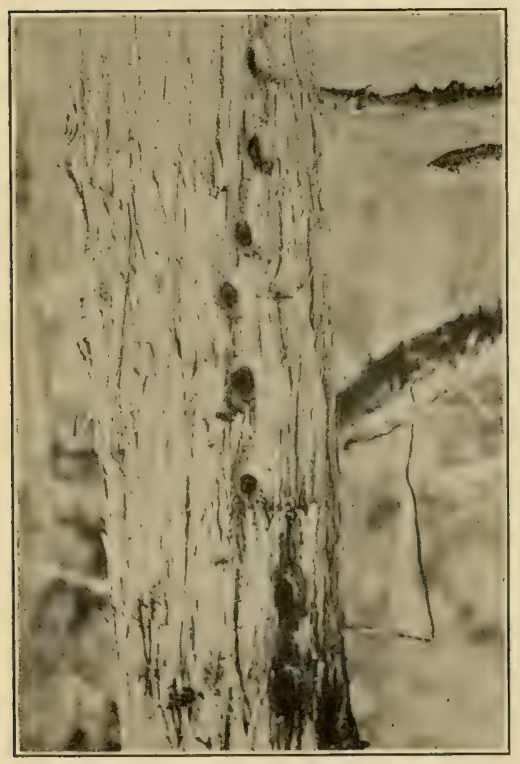

HOLES MADE BY WOODPECKERS DRILLING FOR BORERS

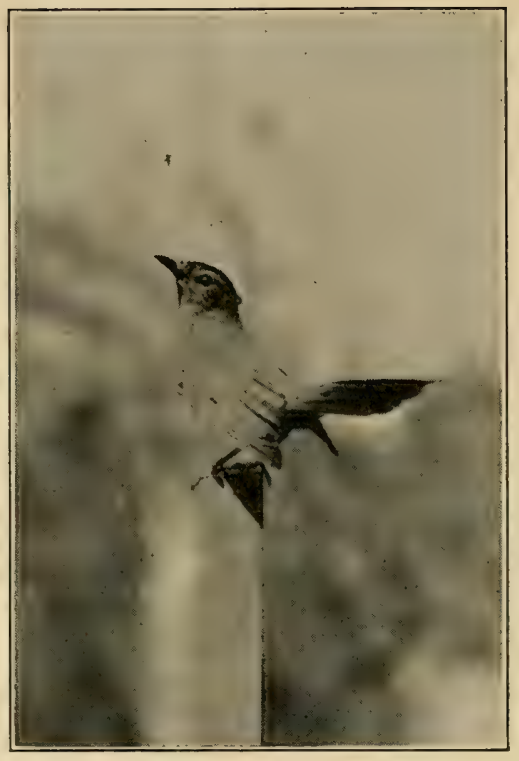

CATBIRD

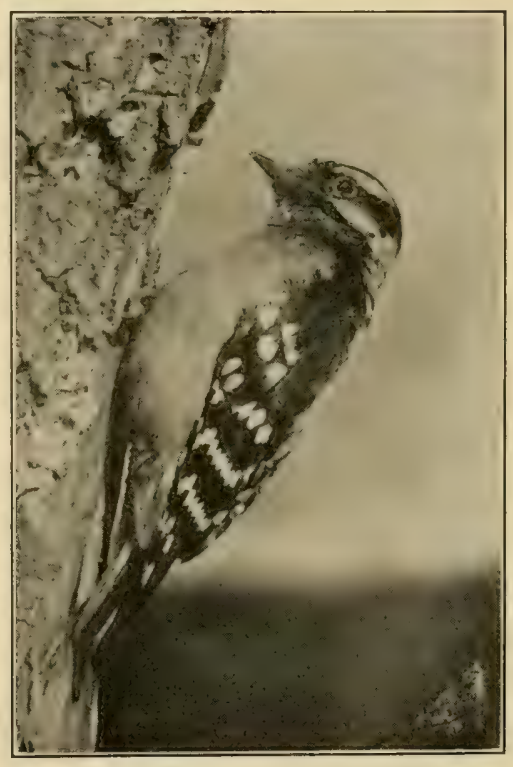

DOWNY - WOODPECKER 
393. HaIry WoOdPecker (Dryobates villosus villosus.)

This fine annual resident has the same color markings as the familiar Downy (black and white), lacking only "Downy's" black spots in the white of the side tail feathers. It is much larger than "Downy," and wilder, and has a more rattling call. It keeps more to the woods and to the high tree tops.

394b. Batchelder's WoOdPecker (Dryobates pubescens homorus.)

A summer resident in the western counties of South Dakota. Similar to the Downy Woodpecker, but having fewer spots on the wing, and with under parts lighter.

394c. Downy WoOdPecker (Dryobates pubescens medianus.)

Our smallest and most common Woodpecker. Colors black and white, like those of Hairy, with the exception above noted. The males of both "Hairy" and "Downy" have a red patch across the back of the head. An annual resident.

400. Arctic Three-toed Woodpecker (Picoides arcticus.)

Found in the Black Hills and the forest reserves of Harding County. Probably an annual resident, but not common. About the size of the Red-headed Woodpecker. Two toes in front and one behind. Back black; under parts whitish. Crown yellow in male and black in female.

402. Yellow-Bellied - Sapsucker (Sphyrapicus varius varius.)

This fine bird belongs farther east, but is occasionally seen as an irregular migrant in South Dakota, though rarely found as a summer resident. The general colors are black and white with a yellowish wash on the belly. Crown and throat red.

406. Red-HeAded WoOdPecker (Melanerpes erythrocephalus.)

There is no mistaking this tricolored summer resident. Its red, white and blue black are spread on in large patches, and it has no other colors. It is often seen by the roadside on fence posts and telegraph poles, which it uses at watchtowers from which to detect insects in the grass. It will even take a passing one on the wing. It is regarded as a lazy bird, and prefers to gather its food as above stated rather than to search and chisel for insects like its more industrious cousins. 
408. LeWis's WOODPECKER (Asyndesmus lewisi.)

A summer resident of the Black Hills. Crown and back dark green. Neck and breast gray; belly ruby; cheeks dark red. Slightly larger than the Red-headed Woodpecker.

409. Red-bellied Woodpecker (Centurus carolinus.)

The range of this Woodpecker is the "eastern United States" but it has been authoritatively recorded from eastern South Dakota.

It is slightly smaller than the Red-headed Woodpecker. Crown and nape red; back and wings barred with black and white. Throat and breast gray; lower parts of belly red. Crown of female gray; otherwise similar to the male.

\section{2a. Northern Flicker (Colaptes auratus luteus.)}

This is our largest, most widely distributed, and most beautiful Woodpecker. It is even found nesting west of the Missouri River in fence-posts, far from trees. Its colors are manybluish gray, pinkish brown, scarlet, yellow, black, white, golden, tawny, ash, lilac brown, olive brown. Yet though so many, with some of them very distinct, these colors are exquisitely blended. The Flickers are often seen upon the ground, for their favorite food is ants. They often return to the same nest, excavating a little deeper each year.

Flickers frequently pass the winter in the southeastern part of the State, especially when the wild grape crop is plentiful.

\section{Red-Shafted Flicker (Colaptes cafer collaris.)}

A summer resident of the western part of the State. Back gray, barred with black; crown grayish brown. No red nape band; sides of throat red instead of black, as in the Northern Flicker. Throat gray; under wings and tail light salmon. Females do not have the red throat patch.

Specimens have been taken along White River that are thought to be hybrids. They much resemble this species but lack the salmon shades under the wings and tail. 


\section{FAMILY CAPRIMULGIDE. GOATSUCKERS}

Five species of Goatsuckers-two Whippoorwills and three Nighthawks-are summer residents of South Dakota.

The Goatsuckers are birds of the morning and evening, between day birds and night flying Owls. By day they are perched on fence posts, limbs of trees or on the ground, and they are so nearly like their surroundings that, but for their form, the eye could scarcely detect them. At evening these birds mount on wing and may be seen circling and wheeling high in the air, where they gather flying insects and moths into their large, bristle rimmed mouths. Their two white eggs are always laid upon the ground or upon leaves.

417. Whippoorwill (Antrostomus vociferus vociferus.)

This bird resembles the Nighthawks but is slightly smaller, and gray predominates on the upper parts rather than the mixed colors.

A bird of the woods, where moths in abundance fly at night. In the day it perches lengthwise upon a limb or beside a stump, and its protective coloration is almost perfect.

Its call, a repeated "whip-poor-will," has been heard from the woods along the Missouri River and as far north as Brookings.

\section{POorwill (Phalaenoptilus nuttalli nuttalli.)}

A summer resident west of the Missouri River. Smaller than the Whippoorwill and with more rufous plumage, the general appearance being lighter. It always rests on the ground during the day.

420. Nighthawk (Chordeiles virginianus virginianus.)

The range of this Nighthawk is east of South Dakota, but it is frequently seen in the eastern half of the State.

About ten inches in length, and the darkest of all the Goatsucker family. Abore, black with white and buff mixed; under parts black, barred with white. Throat white in the male and rusty in the female.

Just as the Whippoorwill is a bird of the woods, the Nighthawk is a bird of the prairies. 
420a. Western Nighthawk (Chordeiles virginianus henryi.)

A subspecies, very common west of the Missouri River and not rare in the eastern part of the State. Similar to the preceding but lighter, more buffy both above and below.

420c. Sennetr's Nighthawk (Chordeiles virginianus sennetti.)

Another subspecies of the Nighthawk family, but smaller than the preceding, and the palest of them all in color. It is also a bird of the plains, but it seems to follow the foothills of the mountainous districts more closely than the other species.

A summer resident. Habits the same as the others.

\section{FAMILY MICROPODIDE. SWIFTS}

Two species of Swifts live in our State during the summer. They are well named, as few birds can surpass them in speed, and they spend most of the day on the wing hunting for insects.

One noticeable characteristic of the Goatsuckers and Swifts is their very small feet. They are all valuable birds as insect destroyers.

\section{Chimney Swift (Chaetura pelagica.)}

Before chimneys came to this country these insect eaters slept and rested in hollow trees; now they may be seen at dusk by hundreds circling over buildings and, one by one or by twos or threes, dropping into high chimneys, where they perch for the night, clinging to the sides. Their feet are so small that they can perch only by clinging, supported by their stiff, spiny tail feathers. It has been said that they can fly all day without resting, living literally on the wing. They even break off the small twigs of which their nests are built as they fly past dead tree tops. These twigs are glued together and to the inside of the chimney with a saliva which they secrete.

The Chimney Swifts are about five inches long from tip of tail to end of bill, but their wings are unusually long and extend beyond the tail. Above, greenish black or dark gray; belly lighter but gray at throat. A summer resident. It is not known yet where they pass the winter. 
425. White-throated Swift (Aeronautes melanoleucus.)

Common summer resident in the badlands of South Dakota. Larger than the Chimney Swift. Above and sides greenish black; throat, belly and flanks white. Tail slightly forked. Nests in holes in inaccessible sides of cliffs.

\section{FAMILY TROCHILIDE. HUMMINGBIRDS}

Hummingbirds are the smallest of all the birds and, as far as we know, only one species visits South Dakota long enough to raise one brood of young; after which it departs for tropical regions.

This exquisite species gathers its food from the flowers of our gardens, but must be carefully distinguished from equally large moths which gather their food in the same way, poising on wing before flowers in hummingbird fashion.

428. Ruby-throated Hummingbird (Archilochus colubris.)

The smallest and one of the most beautiful of our birds. About three and one half inches in length. The male above is a glossy golden green; belly gravish and throat ruby. Tail forked. In the female the throat is gray, and the tail is not so prominently forked.

Breeds occasionally over the State. The nest is fastened to the top side of a horizontal limb and consists of downy material supported on the outside by lichens, which are apparently glued on by saliva which the bird secretes, or by some gummy substance gathered by the builder. Two white eggs are deposited.

\section{FAMILY TYRANNID王. FLYCATCHERS}

The Flycatchers are named for their habit of catching insects on the wing. This is their regular way of securing food. They do not fly continuously howerer, like Swallows and Swifts, but dart out upon their prey from some perch, usually a dead limb or telephone wire. They are all summer residents and do not arrive in the spring until numerous flies are on the wing. They have broad bills and bristled mouths like all fly-catching birds. A number of the smaller ones are so similar in size and 
color that it is not easy to tell them apart, but a knowledge of their nesting habits will be helpful. None of them is classed as a singer.

The Kingbird is the most abundant in our State and during the last two weeks of August thousands are seen in loose flocks along the Missouri River. Their movement is always down the river as though they had begun their southward migration but were loitering by the way. As they fly from grove to grove some are racing and chasing and picking at their fellows in a playful mood; others sail over the water, occasionally swooping down for a drink, which they always take on the wing; others are catching insects, and frequently one comes out of curiosity to inspect a passing boat. They remind one of a crowd of boys returning from school. Most of these Kingbirds, of course, are young and are migrating for the first time. If the weather remains mild doubtless their whole southward flight will be made in this way, as it is customary for birds that feed on the wing to migrate rather slowly by day and feed as they go.

\section{KingBIRd (Tyrannus tyrannus.)}

Sometimes called Bee Bird. Above, slate color, with a white margin across the end of the tail. Below, whitish. A reddish orange patch on the crown somewhat overlaid by longer feathers. The same in size and general habits as the Arkansas Kingbird. These two large Flycatchers are often seen in the same neighborhood. They frequent the vicinity of homes and barns where there are trees, and are exceedingly useful in killing disease carrying flies, destroying robber flies, which are so harmful to bees, and driving away chicken eating Hawks.

\section{Arkansas Kingbird (Tyrannus verticalis.)}

More commonly called Arkansas Flycatcher. This bird is like the well known Kingbird in size, shape and general habits, but gray in color, with the outer tail feathers margined with white, and belly yellow. A reddish orange patch on the crown as in No. 444. Few of these birds are found in the extreme eastern part of our State, but their numbers increase as one goes west, their range extending to the Pacific coast. 


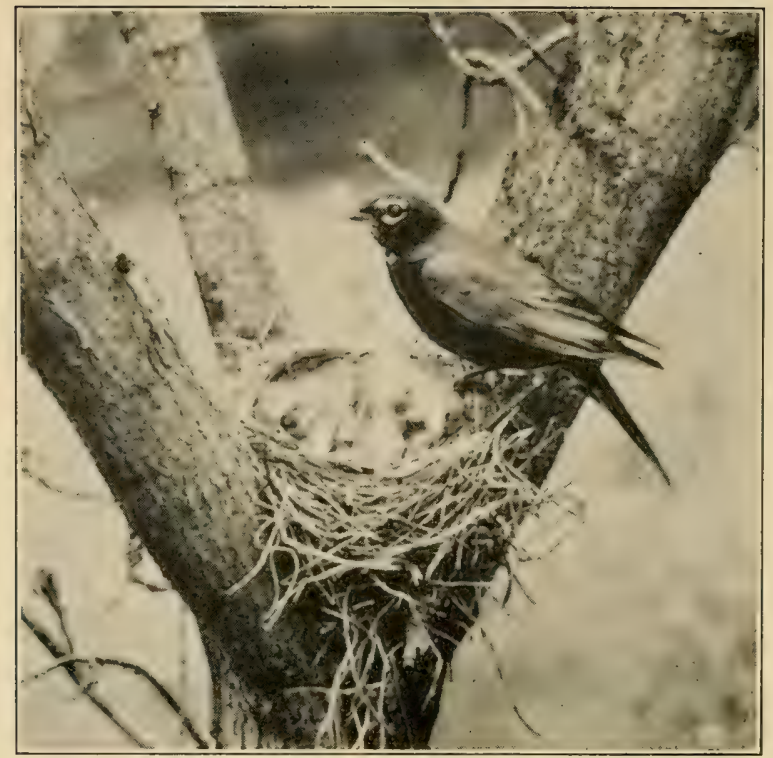

ROBIN'S NEST

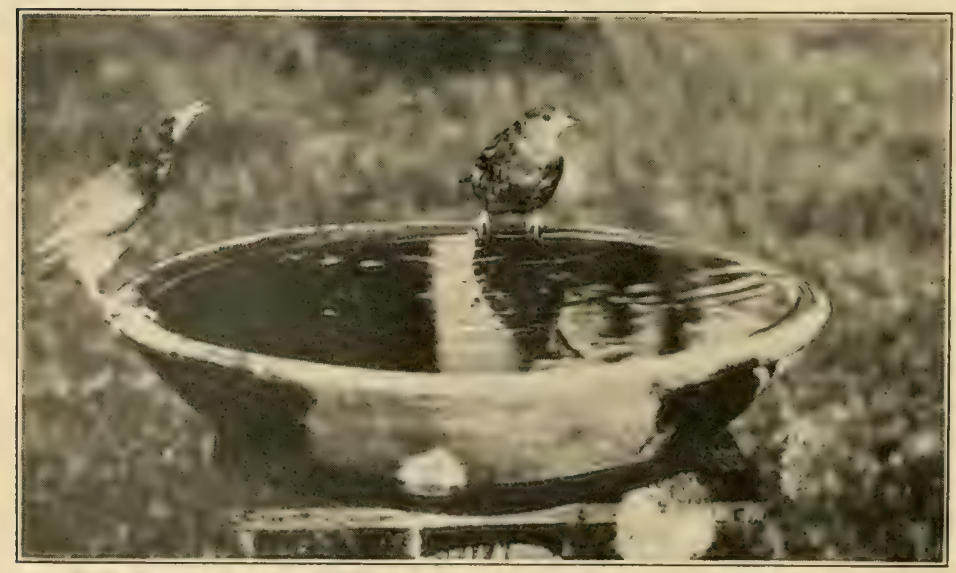

TWO FEMALE BALTIMORE ORIOLES AT THE BATH 
456. - Phoebe (Sayornis phoebe.)

One should distinguish carefully between "Phocbe" and "Pewee"; and one should not confuse the name "Phoebe" with the "phe-bee-ee-ee" note of the Chickadee.

The Phoebe is lighter colored than most Flycatchers of its size. It always builds its nest under a bridge, when it can find one, plastering its half-saucer to the side of a beam like a Barn Swallow. Its note is an emphatic "phee-bee," usually accompanied with a nervous flirt of the tail. A summer resident.

\section{SAy's Phoebe (Sayornis sayus.)}

A summer resident west of the Missouri River. Nearly as large as the Kingbird, but gray above with black tail. Throat and breast gray, changing to a rusty brown on belly.

\section{Olive-Sided Flycatcher (Nuttallornis borealis.)}

This rare Flycatcher has been observed for several summers at Pierre by Miss Sophia DeLand, Miss Abbie Whitney and Mr. A. E. Beaumont. So certain of its identification are they that we are glad to include it in this Bulletin. They report that one of its favorite perching places is on the dome of the State Capitol, where it is often seen and heard. As it is a constant visitor through the summer it more than likely nests in the vicinity.

It is about seven inches in length. Above it is gray with a slight tinge of brown. The throat and belly are light yellow, while the breast is gray but tinged with yellow. The yellowish, long, brushy-like feathers under the wings and sides of rump are prominent. This description is given from a specimen taken in Colorado in May.

461. Wood Pewee (Myiochanes virens.)

The Pewee is darked colored than the Phoebe, with a slight tinge of olive green above and a touch of yellow on the gray belly. Its call is decidedly plaintive, a soft, rather hopeless "pee-awee." It is famous for its exquisite nest, which it saddles neatly on a horizontal limb and covers so completely with lichens that it can scarcely be distinguished from the limb itself. 
462. Western Wood Pewee (Myiochanes richardsoni richardsoni.)

Found in the Black Hills. Similar to the preceding but duller, and seldom shows the green or yellow tinge. Nesting habits the same.

464. Western Flycatcher (Empidonax difficilis difficilis.)

This is also a western form found in the Black Hills. Among the smallest of our Flycatchers. General appearance gray, but yellowish on back and under parts.

466. Traill's Flycatcher (Empidonax trailli trailli.)

This is a western species but nests frequently in the State. About six inches in length. Upper parts are gray tinged with brown; below, white and gray.

466a. Alder Flycatcher (Empidonax trailli alnorum.)

This is an eastern form but there are specimens in the University Museum from Walworth, Sanborn and Clay counties which have been identified by $\mathrm{Mr}$. H. C. Oberholser of the United States Biological Survey. It is about six inches in length. Above, grayish; wings and tail not as dark as in most Flycatchers; below, whitish.

467. Least Flycatcher (E mpidonax minimus.)

Sometimes called "Chebec" from the similarity of its vigorous note to this word. Smallest of the Flycatchers and with tail slightly forked. Similar in color to the Alder Flycatcher. It places its nest in the fork of tree or bush.

\section{FAMILY ALAUDID瓜. LARKS}

There are fourteen species and subspecies of Larks in the United States. Two of the latter are common to South Dakota, the Prairie Horned Lark to the eastern part of the State, and the Desert Horned Lark to the western portion.

The Horned Lark, sometimes called "Shorelark," is named from the two tufts of feathers on its head which, when raised slightly, simulate horns. It is a modest but well marked bird of fine spirit, and the only Lark native to this country (the Meadowlark is a Starling, and the Skylark is a straggler from the Old 
World). It is seen on prairie and pasture hills, about straw stacks in winter picking up weed seeds and grain, in our barnyards during storms feeding with the cattle, and even on country roads gathering spilled grain from the farmer's loaded wagon.

474b. Prairie Horned Lark (Otocoris alpestris praticola.)

Some call it "Snow-bird," others do not distinguish it from a Sparrow. It is, however, distinctly marked, with its black crown horseshoe terminating in horns, its black mustache, and its black breast patch. Moreover, the gray of its general plumage is washed, especially on the shoulders, with delicate lilac brown. With the exception of the Great Horned Owl, it is the first bird to nest in spring. A full clutch of eggs has been - seen a number of times in March when snowbanks were visible on the distant hills.

474c. Desert HoRned LARK (Otocoris alpestris leucolaema.)

Similar to the preceding but lighter, the lilac brown tinge not so prominent on back and shoulders. Throat usually yellow. Nesting habits the same as the latter. A resident in the western half of our State.

\section{FAMILY CORVIDE. CROWS, JAYS AND MAGPIES}

This family is well represented in South Dakota, and is so characteristic in habits and plumage that most of them are well known. By varying their food according to season they usually find an adequate supply; and since they migrate only a short distance they are considered annual residents. The Blue Jay is represented during the winter by only a few stragglers in the southern part of the State.

Records show that prior to 1880 there were few Crows in the Territory, but that Ravens were frequently seen. At present conditions are reversed. Has the Crow followed settlers into the State and driven the straggling Ravens farther west?

The whole family is in disfavor and has few friends. They all possess thieving qualities and will occasionally despoil birds' and hen's nests of both eggs and young.

Though not classed as singers they are the most intelligent of our birds and may be taught to articulate some words. 
475. Magpie (Pica pica hudsonia.)

The Magpie is more or less common along the Missouri River and westward in our State, where it is an annual resident. It strays eastward sometimes during the winter. Specimens have been taken at Vermillion in December and January.

The bird is about twenty inches in length, including a very long tail. Head and back black; tail and large wing feathers glossy black; upper wing feathers and belly white.

There is no mistaking this beautiful, interesting and roguish bird. Its harsh notes inform you of its presence and warn you that you are intruding upon its premises. The nest is a bulky affair, sometimes two or three feet in diameter, built of coarse sticks and placed in low, bushy trees. The nest proper is placed in the center of the mass of sticks, and it is almost impossible for a larger animal to get near the seven to nine eggs.

477. Blue Jay (Cyanocitta cristata cristata.)

About eleven inches in length. Above, including its crest, light blue, slightly marked with white and black; below, gray. Easily identified by its harsh call, "jay, jay."

The beautiful color of the Blue Jay belies his character. While ideal about their own nests, these birds frequently rifle other birds' nests and kill their young. They have thicring propensities and often secrete food like Woodpeckers.

484. Canada Jay; Camp Robber (Perisoreus canadensis canadensis.) An annual resident of the Black Hills. Same in size as the Blue Jay. Above, gray except back part of head, which is much darker; below, whitish. Considered a pest around logging camps.

486. RAVEN (Corvus corax sinuatus.)

While frequently seen along the Missouri River and westward in early days, it is found at present only as a straggler in the Black Hills.

It is similar to the common Crow in plumage, but larger, and easily identified by its size, particularly by its large bill.

Habits much the same as the Crow except that in nesting it is more likely to choose a rock shelf or cliff than a tree. 
488. CRow (Corvus brachyrhynchos brachyrhynchos.)

Perhaps the best known bird in South Dakota. An annual resident, gathering in large flocks during the fall and winter and migrating south or east a little way to find more suitable feeding grounds. In the spring they scatter in pairs over the State to nest.

The economic value of the Crow is perhaps a matter of conditions and numbers. The writers have watched hundreds, day after day, making a meal from grasshoppers in the alfalfa fields along the Missouri River. This was during the summers of 1916 to 1919 inclusive, when the grasshoppers were a pest in that locality. To the settlers along the river the crows were a valuable asset, while perhaps in other parts of the State they were committing acts of depredation that would place them in disrepute.

491. Clarke's Nutcracker (Nucifraga columbiana.)

Frequently seen in the pine forests of the Black Hills.

Slightly larger than the Canada Jay, but similar in color. Whole body ashy gray. Wings and middle tail feathers black; outer tail feathers white. Habits much like those of the Pinon Jay.

492. Pinon JAY (Cyanocephalus cyanocephalus.)

Locally abundant in the Black Hills and forest reserves of Harding County. Has been seen in Douglas and Washabaugh counties, and may be found anywhere west of the Missouri River where a few pine trees are growing, as it feeds principally on seeds from the cones of this tree.

It is about the size of the Blue Jay. Its entire plumage is uniform grayish blue. Except during the breeding season it is usually seen in small flocks.

\section{FAMILY ICTERID质. BLACKBIRDS, ORIOLES, MEADOWLARKS}

This is a family of weavers, and includes Orioles, Blackbirds, Meadowlarks, etc. These vary greatly in nest weaving ability, power of song, and beauty of color, but constitute one of our most charming and useful bird families. 
494. BoвoLink (Dolichonyx oryzivorus.)

Found locally over the State as a summer resident.

The male is black with a buffy patch on nape (hind neck), and a broad white streak on lower back which divides on the upper back and reaches to the shoulders. The female above, is buff streaked with black; below, whitish.

A bird of the low prairie which utters its ecstatic, bubbling song on the wing, and in a straight-away flight.

\section{Cow BIRd (Molothrus ater ater.)}

Abundant over the State as a summer resident. Nearly eight inches in length. The male is black with head and neck light brown. Female brownish gray.

To some people a Blackbird is simply a Blackbird, but there are many kinds of Blackbirds, and the Cowbird is the worst. It builds no nest of its own, but lays its speckled egg in the nests of other birds-Redwings, Warblers, Vireos, Towhees, etc. Its egg hatches more quickly than other birds' eggs, and the young grow very rapidly, crowding their nestmates unduly and taking most of the food: this frequently results in the death of the rightful young. Except when watching for opportunity to lay their eggs in other birds' nests they are usually seen in pastures near cattle and horses. They feed on the ground insects disturbed by the stock and not on flies that harass the cows and horses.

497. Yellow-Headed Blackiridd (Xanthocephalus xanthocephalus.)

The gleaming yellow head and throat of the male makes a marked object in field or marsh. The nesting habits are the same as Redwing's. The females of Yellowhead and Redwing are not readily distinguished by the unpracticed observer. A summer resident.

This Blackbird is not so abundant in South Dakota as formerly. Are they decreasing in numbers or have they changed their nesting grounds?

498. Red-winged Black bird (Agelaius phoeniceus phoeniceus.)

The "Redwing" is familiar to every boy, at least in South Dakota. It is a bird of the marsh, of the reed-encircled slough, 


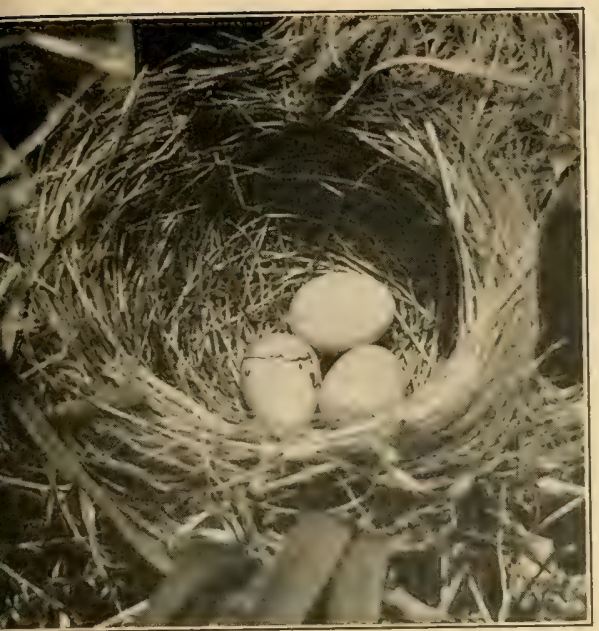

RED-WINGED BLACKBIRD'S NEST

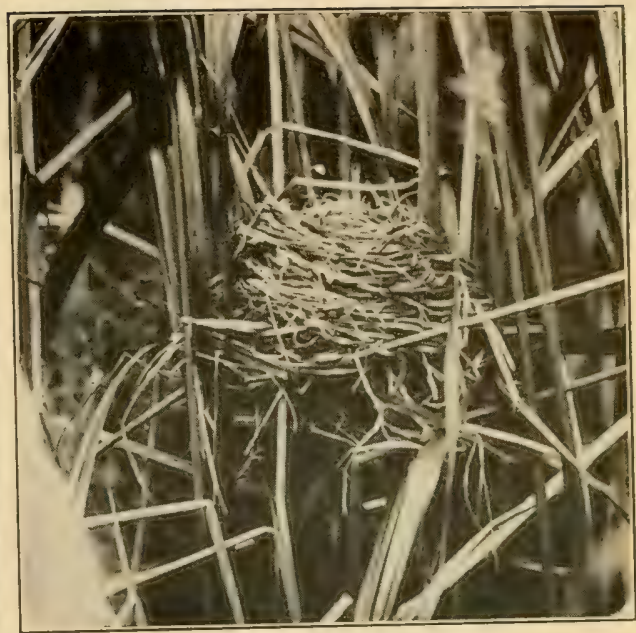

NEST OF YELLOW-HEADED BLACKBIRD

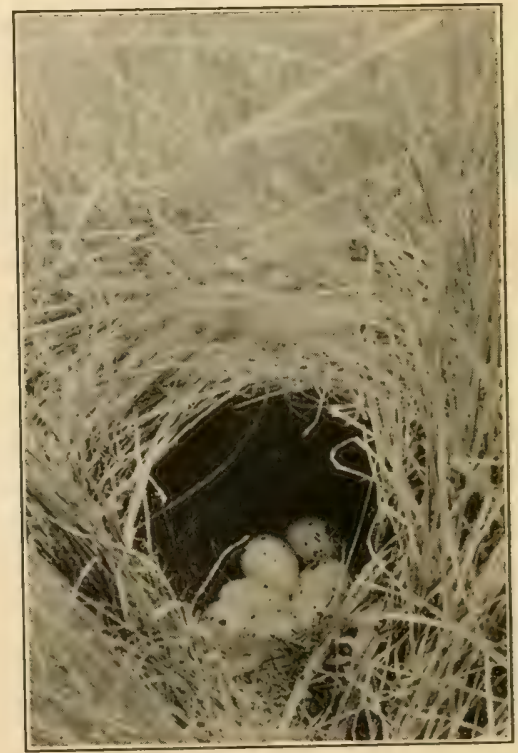

WESTERN MEADOWLARK'S NEST 

and of the willow bordered river. It nests commonly over the State, and, being one of the Starlings, all of which are weavers, it fastens its nest securely among the rushes. Early in the fall these birds gather in large flocks before migrating southward.

498d. Thick-Billed Redwing (Agelaius Phoeniceus fortis.)

Similar in plumage to the preceding but larger, with bill shorter and thicker. Breeds in Western Canada. Seen in South Dakota only in migration. This is the Blackbird observed feeding in large flocks early in winter. Small flocks have been seen in Clay County in January.

\section{1. Western Meadowlark (Sturnella neglecta.)}

There are two species of Meadowlarks in the Northern States, the Eastern (Sturnella magna) and the Western (Sturnell: neglecta). In our latitude the eastern State line of South Dakota is about the dividing line of the range of the two species. For a considerable distance east or west of this line there is much overlapping of their range and perhaps interbreeding, producing intermediates. Some believe that the range of the western form is gradually extending eastward. It is also smaller than the eastern form. There is a wide difference in the song: notes of the two species, and some evidence to justify the suggestion that there may be a variation, both in song and tone, between those west of the Missouri River and the intermediates of the eastern part of the State.

Those west of the Missouri River are all Sturneila neniecta, and doubtless all those east of central Iowa are sturnclin magnu. As far as known no true type of the Eastern Meadowlark has been taken in South Dakota.

The song of this bird is a wonderfully exuberant expression of bird music. It may he heard for half a mile and fairly fills the prairie. There is not room enough for 1 t anywhere else. The singer is sure of his audience and is thrilled and inspired by his surroundings. The songs and calls are exceedingly varied, but the rapturous love song, rendered in full flight, is Nature in her most ecstatic mood, and nowhere is the song finer than in South Dakota.

The home of the Western Meadowlark is on the prairies or in open meadows. As noted elsewhere in this bulletin, the 
Meadowlark is not a "Lark," but a Starling. It was called a "Lark" by the first settlers in New England because it reminded them of the English Skylark. The Starlings are all weavers, and while the Meadowlark builds its nest upon the ground in the hay meadow, it carefully arches it over with dried grass woven into a well shaped roof, and sometimes there is a runway two feet long through the standing grass to the entrance.

The general coloration of the Western Meadowlark is paler than that of the Eastern, and the black crescent on its breast is not so prominent. The yellow of the throat usually extends up on the lower cheeks and the bars on the tail feathers are more distinct.

\section{Orchard Oriole (Icterus spurius.)}

In color the Orchard Oriole is chestnut where the Baltimore is orange. It is slightly smaller and neither so beautiful nor such a good weaver as the Baltimore. It builds a shallower nest and lashes it to twigs and leaves after the fashion of Redwing's nest in the rushes. Indeed this Starling seems to stand midway between Baltimore and Redwing in color, song notes, and weaving ability. The female is olive yellow above and dull yellow below, with black markings. The young of the first year are like the female, but with a black throat.

507. Baltimore Oriode (Icterus galbula.)

The Baltimore is the most expert weaver of the Starlings, as well as the most beautiful in coloration and the most accomplished in song. His long pendant nest is placed in the high tree top, where he is more frequently heard than seen. But with his deep orange body, contrasting with his black head, wings and middle tail feathers, it is more difficult for him to hide than for his modest female with her dull yellow dress. The young males of this Oriole resemble the female the first season. The second season the yellow parts are nearly lemon color and deepen to orange red with age. A summer resident east of the Missouri River.

508. Bullock's Oriole (Icterus bullocki.)

Frequently seen nesting along the sparsely wooded creeks west of the Missouri River, where it seems to take the place 


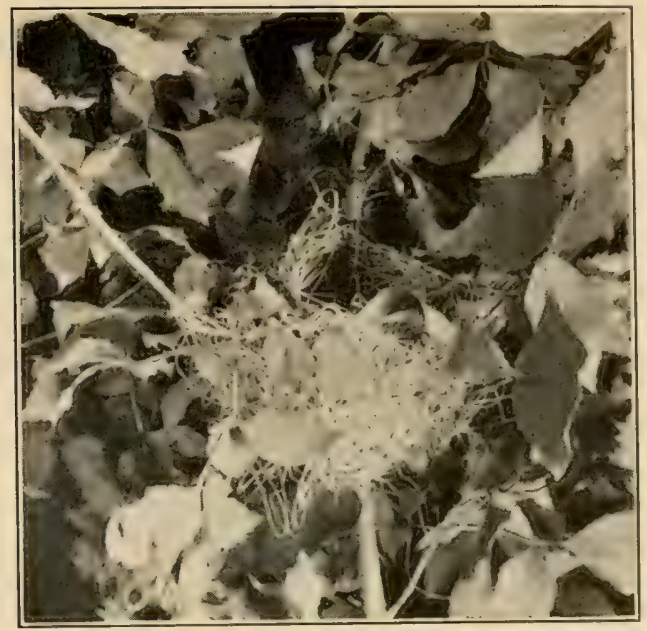

ORCHARD ORIOLE'S NEST

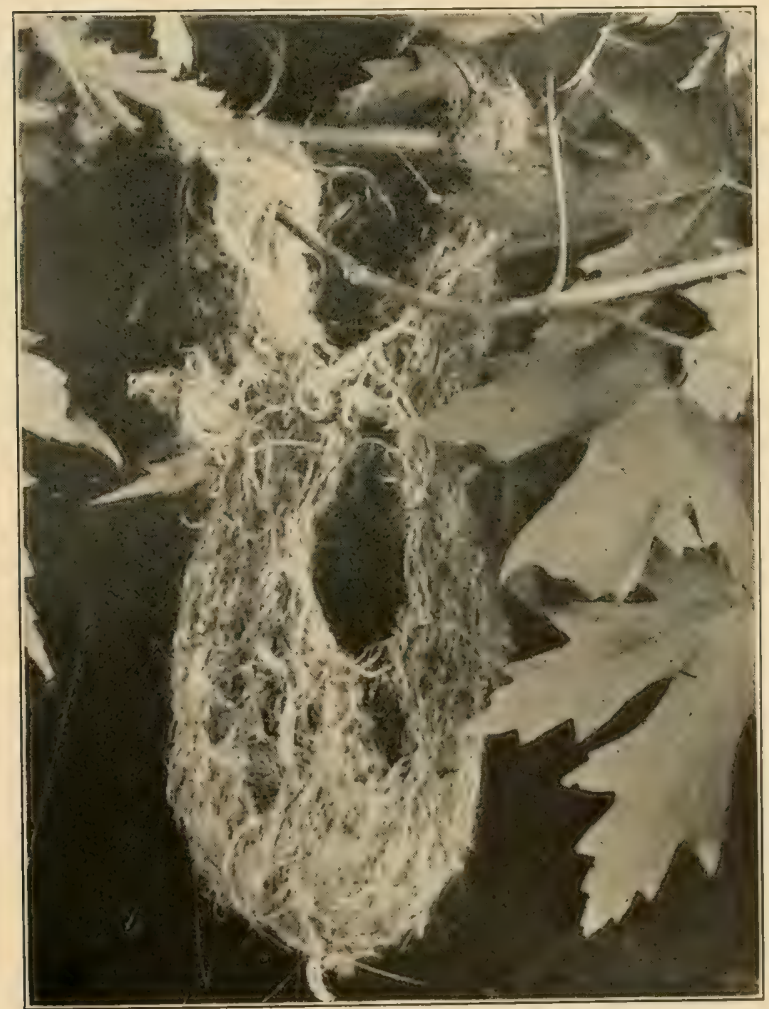

BALTIMORE ORIOLE'S NEST 

of the Baltimore Oriole in our State. It is paler than the Baltimore, the male nearly resembling the female Baltimore, while his own female is dull gray with very little yellow showing. It prefers to nest in tall cottonwood trees, and its basket is not so bulky as that of its eastern cousin. It weaves hair from the tails of horses and cattle into its nest instead of strings or yarn, possibly because these are more available in ranching regions.

509. Rusty Blackitrd (Euphagus carolinus.)

Nests north of us, hence may be looked for only in migration. About the size of the Redwing, but in color the male is greenish black with rusty markings. The female is grayish, with some rusty above and streaked with black below.

Both sexes may be recognized by a whitish line over the eyes.

510. BREWER'S BLACKBIRD (Euphagus cyanocephalus.)

A western species, but frequently seen in migration in South Dakota. Slightly larger than the preceding and distinguished from it by its violet purple head and uniform black body.

511b. Bronzed Grackle (Quiscalus quiscula aeneus.)

This is the largest Blackbird in the State, and the one that comes familiarly about our homes. They are quite unafraid on our lawns, and walk in stately fashion, swinging their long tails from side to side. They sometimes become unpleasantly numerous and crowd other birds out, especially if a good nesting grove is near.

Head and neck steel blue; back and under parts bronze; wings and tail purple. The tail of the old birds is often $\mathrm{V}$-shaped when flying. Nests in shade trees, often several in the same tree.

\section{FAMILY FRINGILLIDE. FINCHES, GROSBEAKS AND SPARROWS}

The Finch family is the largest of our bird families, numbering nearly 600 species, over ninety of which are in North America. They are seed eating birds and have strong bills for crushing their food. The family comprises the Finches proper, 
Sparrows, Grosbeaks, and others. Many of them are fine singers, and some are beautiful in color.

The Sparrows are modest colored birds and not always easily distinguished from each other. They are unpretentious in song and not remarkably interesting to study. We have them with us all the time, but not always the same species: some are annual residents, some winter residents, others summer residents, but most are migrants. They are all of great value in destroying weed seeds, although, like practically all birds, they feed their young on insects. The English Sparrow is known to every child, and for this reason may be taken as the type and measure of them all, some being larger and some smaller; although the English Sparrow is utterly different in habits from all others.

The Grosbeaks are a notable group in this family, much larger than most Sparrows, some of them gorgeously colored, and many noted for sweet song. They have thick, powerful bills for crushing seeds and opening cones.

The Longspurs are distinctively birds of the open prairie. They are named from the unusual development of the hind toe and claw. The unpracticed observer would not distinguish them from Sparrows, to which they are closely related.

\section{Evening Grosbeak (Hesperiphona vespertina vespertina.)}

A winter resident in our State and not abundant. Similar in size to the well known Rose-breasted Grosbeak. Crown and tail black; upper part of wings white, lower part black; back and under parts dark yellow. Female dingy yellow, lighter below. The bill is thicker than in other Grosbeaks.

\section{Pine Grosbeak (Pinicola enucleator leucura.)}

This bird is rare in the State as a winter resident. Mr. A. T. Solem, a keen bird observer of Union County, says, "In earlier years I saw it frequently, but rarely of late." Mr. Charles E. McChesney also saw it at Fort Sisseton in 1898.

It is about eight and one half inches in length. Male gray, ringed with rosy red but gray predominating on center of back, wings and under parts. Female gray and not tinged with red. 


\section{Purple Finch (Carpodacus purpureus purpureus.)}

A rare summer resident in South Dakota. Thick bill; forked tail; head, back and breast pinkish purple; lower belly whitish; wings and tail slaty. About the size of the English Sparrow, which the female and young resemble. While it has none of the obnoxious habits of the English Sparrow, it is supposed to be its nearest relative.

\section{Crossbill (Loxia curvirostra minor.)}

The Crossbill may be an annual resident in our western ticr of counties. It has been taken in the eastern part of the State as a migrant. About the size of the English Sparrow. As the name implies, the two halves of the bill are crossed, adapting it for twisting seeds from pine cones. These seeds are their main food and they often eat hanging to branches head downward.

Wings and tail slaty gray. Head, back and under parts brownish red. Females and young dull olive green; rump and under parts tinged with yellow.

522. White-winged Crossbill (Loxia leucoptera.)

Size similar to the Crossbill ; range farther north; irregular in migration during winter in South Dakota.

Male dull carmine red, lighter on rump; wings black with two white bars; female and young brownish, tinged with yellow; bill crossed as in the preceding species. The Crossbills are great wanderers during winter and for that reason have been called the "gypsies" among birds; however, it may be said that their habitat is the coniferous forests of North America.

\section{ReDPoll (Acanthis linaria linaria.)}

The somewhat obscured red crown patch and rosy breast help to distinguish this cheery little bird in winter from numerous Sparrows. It nests in the northern part of the Northern Hemisphere, but in winter it comes to us and may be seen feeding on weed seeds, usually about the edges of groves.

529. GoldFinch (Astragalinus tristis tristis.)

This charming bird is frequently called "Wild Canary," but there are no Wild Canaries in this country. Its black cap, wings 
and tail, contrasting strongly with the yellow body, easily distinguish it from the Yellow Warbler, which is wholly yellow. It is an abundant annual resident. In winter the yellow of the male has disappeared. Males, females and young can scarcely be distinguished in their grayish brown plumage as they feed by half dozens on sunflower or other weed seeds. They believe in long courtships and do not nest until late June or early July.

\section{Arkansas Goldfinch (Astragalinus psaltria psaltria.)}

Probably rare in our State but it has been found nesting in Sanborn County. It is much shorter than the preceding; has the black cap, wings and tail, and yellow belly, but is wholly greenish gray on back and cheeks. It may easily be distinguished from the preceding by its smaller size.

\section{Pine Siskin: Pine Finch (Spinus pinus.)}

Has the appearance of a small Sparrow. Above brownish black, feathers edged with gray; below, lighter; outer tail and wing feathers edged with yellow; tail forked; bill sharp. A winter resident in South Dakota.

\section{Snow Bunting (Plectrophenax nivalis nivalis.)}

Frequently in large flocks, and exceedingly beautiful in their soft, white winter plumage. Named from the fact that as they circle and alight on the northern prairies they are thought to resemble whirling and falling snow. The Snow Bunting is one of the Longspurs, possessing the long hind-toe nail. Feeds on weed seeds; nests in the Arctic regions.

\section{Lapland Longspur (Calcarius lapponicus lapponicus.)}

We see these birds only in winter, when they come to us from their snow covered northern home on the wings of a storm. In their winter plumage the unpracticed observer would take them for Sparrows, but in summer the males are beautifully marked. The cap, cheeks, throat and upper breast are black. The long hind-toe nail will help to identify tisen.

537. Smith's Longspur (Calcarius pictus.)

This is also a migrant and Sparrow-like in coloration, except that the under parts are buft. 


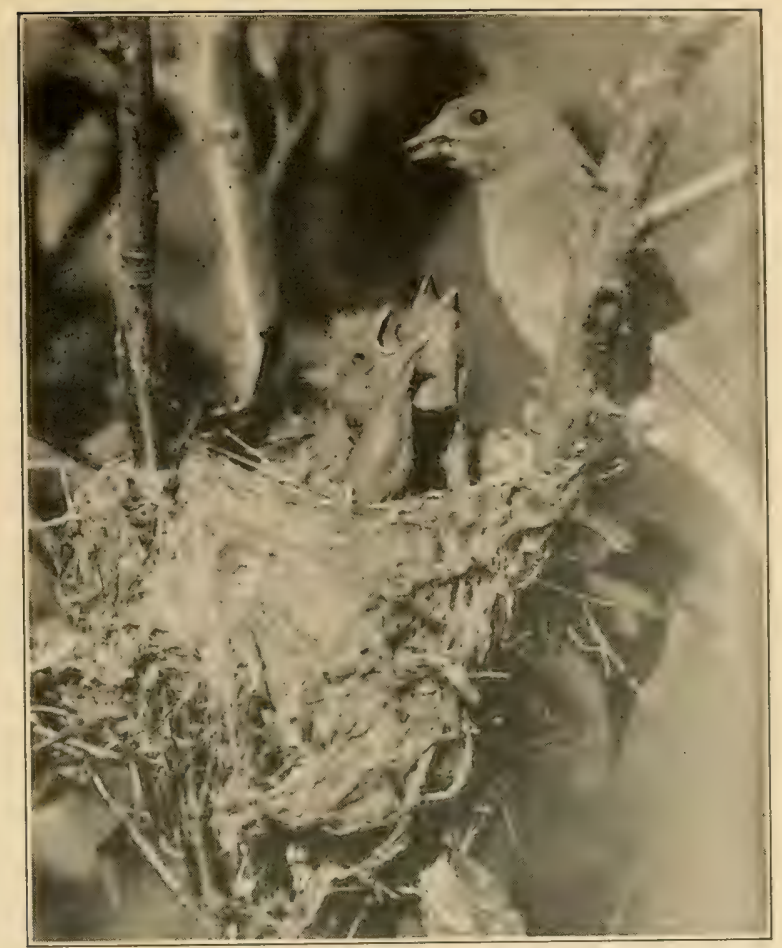

GOLDFINCH AND HER YOUNG

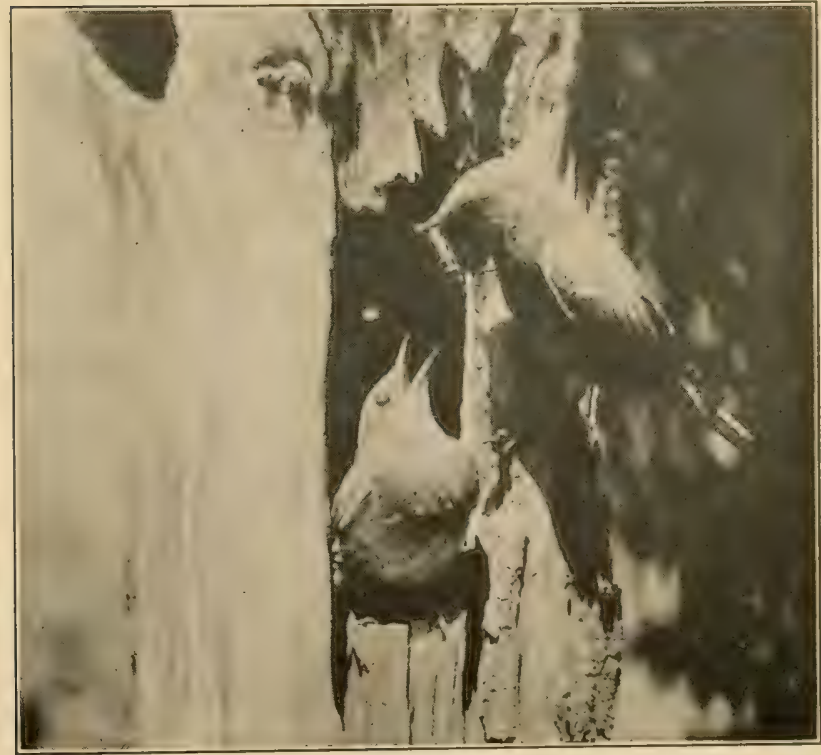

MALE BLUEBIRD FEEDING HIS MATE 

It is an early breeder in northern British America, as young have been taken in Sully County the eighteenth of August.

538. Chestnut-collaned Longspur (Calcarius ornatus.)

One of the most familiar birds of our unbroken prairie. To the general Sparrow colors are added a black cap, chestnut collar, white throat, and breast heavily washed with black. It nests by a bunch of grass and its sweet warble is uttered on the wing after the fashion of the Lark.

539. McCowan's Longspur (Rhynchophanes m'cowni.)

This bird is similar in form and habits to the preceding, but the shoulder of the wing is chestnut instead of the collar, the black of the breast does not extend over the belly, and there is a black mustache. This species is not so plentiful as the last, but both are found nesting on the same prairie hills.

540a. Western Vesper Sparrow (Pooecetes gramineus confinis.)

A summer resident, and one of our smallest Sparrows. shoulder patch and white margined outer tail feathers. It sings from some lone pasture tree or bushtop in the evening.

542a. Savannah Sparrow (Passerculus sandwichensis savanna.)

A summer resident, recognized by the yellow line over the eye, together with the well spotted breast. Most abundant in migration.

542b. Western Savannah Sparrow (Passerculus sandwichensis alaudinus.)

Similar to the preceding, but its general appearance is paler, with the line over the eyes gray instead of yellow, and a more slender bill.

A western species and a migrant in South Dakota.

545. Baird's Sparrow (Ammodramus bairdi.)

A Sparrow of the western plains, which nests north of us.

Crown buffy; back black and brown; below, white streaked with black.

546a. Western Grasshopper Sparrow (Ammodramus savannatum bimaculatus.)

A summer resident, and one of our smallest Sparrows. 
It is frequently seen on a fence by the roadside or on tall weeds in meadows. It is easily recognized by the action of wings in flight like a Hummingbird or by its insect-like song.

547a. Western Henslow's Sparrow (Passerherbulus henslowi occidentalis.)

A small Sparrow that nests in the State. Above, reddish brown streaked with gray; below, white; tail feathers pointed.

548. Leconte's Sparrow (Passerherbulus lecontei.)

A migrant in the southeastern part of the State, nesting west of the Missouri River.

Size of the preceding but no yellow on wings; otherwise not unusually marked.

549. 1. Nelson's Sparrow (Passerherbulus nelsoni nelsoni.)

A summer resident. All the tail feathers are pointed, the outer ones being shortest. Breast buffy.

\section{LARK SPARROW (Chondestes grammacus grammacus.)}

A summer resident and beautiful singer, a thoroughly lovable bird. The sides of the head have distinct chestnut patches, and the outer tail feathers are margined with white, which extends to broad tips on all but the central feathers. The song may be recognized by a distinct nasal note in the middle of it. They nest upon the ground, but love the edges of towns where there are a few trees. Very common on the grassy hillsides bordering the Missouri River.

\section{HaRris's SPARRow (Zonotrichia querula.)}

An abundant migrant. A fine large Sparrow, recognized instantly by the black head, throat and upper breast, and by the clear, rather plaintive whistle. For a few days in spring and fall in the southeastern part of the State the bushes are full of them: suddenly they are gone.

\section{English Sparrow (Passer domesticus.)}

Introduced from England in 1851. Too common in cities, towns and around farm buildings to need description. The color of the male would be pleasing if only he were clean. So dogged 
in disposition are these birds of city gutters that they crowd other birds out. They attempt to occupy every house made for Bluebirds and Wrens, seek to monopolize every bird bath and food box, and even tear up the lining of other birds' nests and throw out their eggs. Their young are raised on insects but at all other times their food is chiefly grain. They are considered a pest but must not be confused with our native Sparrows, which are all beneficial.

554. White-crowned Sparrow (Zonotrichia leucophrys leucophrys.)

A medium sized Sparrow seen only in migration. White crown and white stripe over eyes separated by a black stripe reaching to bill.

554a. Gambel's Sparrow (Zonotrichia leucophrys gambel.)

A western species of No. 553 and very similar but for white stripes over eyes reaching to bill. In South Dakota only in migration.

558. White-throated Sparrow (Zonotrichia albicollis.)

A common migrant. Called the Peabody Bird and easily recognized by its white throat, black crown divided by a white stripe, and white stripe over the eye, yellowish at the front.

559. Tree Sparrow (Spizella monticola monticola.)

These are winter residents, and come to us in large numbers. Loose flocks of them are seen wherever there are groves or bushes, and they are easily recognized by the dark spot in the center of a gray white breast. They are cheery birds, and ere they return north in spring they "tune up," so that their combined call notes and songs amount almost to chorus singing.

The Western Tree Sparrow No. 559a is no doubt the prevailing subspecies of western South Dakota.

560. Chipping Sparrow (Spizella passerina passerina.)

A summer resident. This little gem, easily recognized by his small size, chestnut crown, distinct white stripe over eye, black line through eye, and black forehead, loves the trees about our homes. His song is a single trill-"chip, chip, chip, cheeee-ee." 
560a. Western Chipping SPARrow (Spizella passerina arizonae.)

Similar to the eastern form, but paler above. Has been taken in Fall River County.

561. Clay-Colored Sparrow (Spizella pallida.)

A common migrant, frequently nesting in the State. The colors are paler above than is common with Sparrows; belly white. The song has a distinct nasal note.

563a. Western Freld Sparrow (Spizella pusilla arenacea.)

A summer resident. This is a slender, light colored Sparrow, with a grayish brown cap. It is unfortunately named, for it loves the trees which border fields rather than the open spaces. Its song, which is easily recognized, is a vigorous "cher-weecher-wee, chee-o-dee-e-e-e-e-e" in ascending scale.

566. White-Winged Junco (Junco aikeni.)

A summer resident in the Black Hills and forest reserves of Harding County. Slaty gray above; two white wing bars and three outer tail feathers white.

567. Slate-COlOREd Junco (Junco hyemalis hyemalis.) "SNowbird"

A frequent winter resident in the southeastern part of the State, seen in flocks about thickets and often near homes feeding with Sparrows. A sleek, slate colored bird, about the size of the female English Sparrow. The bill, belly and outer tail feathers are white.

581. Song Sparrow (Melospiza melodia melodia.)

A frequent migrant in the eastern part of the State, easily recognized by its heavily streaked breast, the streaks merging into a dark patch at the center. Above reddish brown with black streaks.

It is an attractive singer.

581 j. Dakota Song Sparrow (Melospiza melodia juddi.)

Common over the State in migration and probably nests west of the Missouri River.

Similar to No. 581 but paler above; the black patch on the belly is less prominent, with more white showing. 


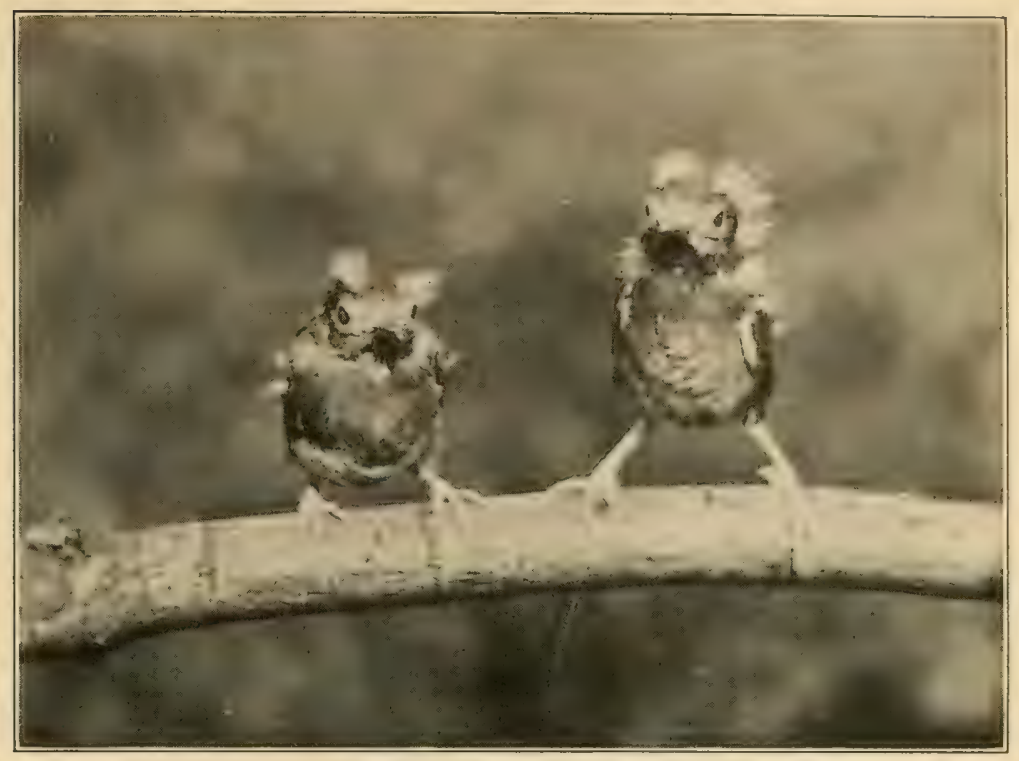

YOUNG BALTIMORE ORIOLES

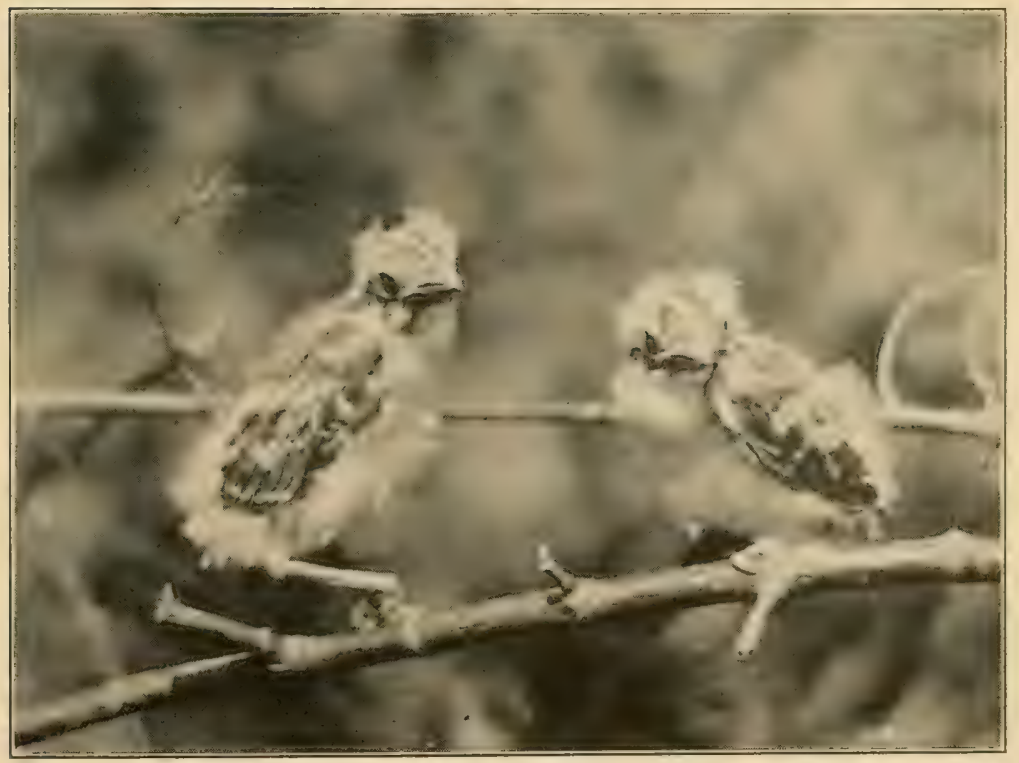

YOUNG ROSE-BREASTED GROSBEAKS 



\section{Lincoln's Sparrow (Melospiza lincolni lincolni.)}

A small Sparrow rather dark colored, profusely striped, with a brownish area on the breast. It loves to run about on the ground, going in and out of brush piles. A migrant.

585. Fox Sparrow (Passerella iliaca iliaca.)

A somewhat irregular migrant in the eastern part of the State and larger than most of our Sparrows.

Above, gray and brown; below, profusely marked with reddish brown spots; tail reddish brown.

587. Tow HeE (Pipilo erythrophthalmus erythrophthalmus.) "Chewink."

This splendid bird of the underbrush is a little larger than an Oriole. The male has black head and back, chestnut sides, and white belly. Three outer tail feathers also are white. It is named for its song, "to-hee-ee-ee," uttered with a distinct pause after "to," almost as though the song came from two birds. Chewinks are found only in the eastern part of the State. They are often seen scratching up leaves under bushes like barnyard hens. Summer residents.

588. Arctic Towhee (Pipilo maculatus arcticus.)

Abundant in migration over the State and probably breeds west of the Missouri River. Larger than the preceding. More white on wings but only one third of outer tail feathers white. Habits same as No. 587.

593. Cardinal (Cardinalis cardinalis cardinalis.)

The Cardinal is nearly as large as the Blue Jay. The male is flaming red but for the black throat and forehead. Female, dull brownish red. Both have crest feathers. The Grosbeaks all have massive bills for the crushing of seeds. South Dakota is at the northern limit of their range, but several pairs are now annual residents in the timbered area of Lnion and Clay counties.

595. Rose-breasted Grosbeak (Zamelodia ludoviciana.)

The male is black and white, with $\mathrm{V}$-shaped rose colored breast. The female is as homely as the male is beautiful. Her 
general appearance is brownish mixed with some white. She may easily be taken for a large Sparrow.

This splendid bird is now common in the southeastern part of the State and rivals our best songsters in musical performance. It is the only bird that feeds on potato bugs. A few pairs of these summer residents in the garden will keep the potato patch free from these pests.

\section{Black-HeAded Grosbeak (Zamelodia melanocephala.)}

A rare summer resident in the western part of the State, where it takes the place of the Rose-breasted Grosbeak. It prefers the wooded creeks and ravines rather than the thick pine woods.

Head black; neck, rump and under parts light brown; wings with white patches; yellow patch on belly; back streaked with black and brown.

597a. Western Blue Grosbeak (Guiraca caerulea lazula.)

Known to nest along the Missouri River as far north as Pierre. The male is bright blue with wings grayish slate and two chestnut bars. The female is grayish brown above and lighter below.

598. Indigo Bunting (Passerina cyanea.)

This beautiful Bunting, whose every feather is indigo or blackish, is about the size of a Canary. The female is brownish. Like the Tanagers, they are not plentiful, but scattered sparingly over their range. They love the edges of outlying groves, and where available the male loves to perch on a telegraph wire while singing.

599. Lazuli Bunting (Passerina amoena.)

Probably breeds in the western part of the State. A male was seen along the Missouri River in July, 1915.

About the size of the Indigo Bunting. Head, neck and upper parts blue; back mixed with black; breast light brown; belly white; two white bars on the dull gray wings.

604. Dickcissel (Spiza americana.)

"Dickey", while suggesting a Sparrow, is marked not un- 



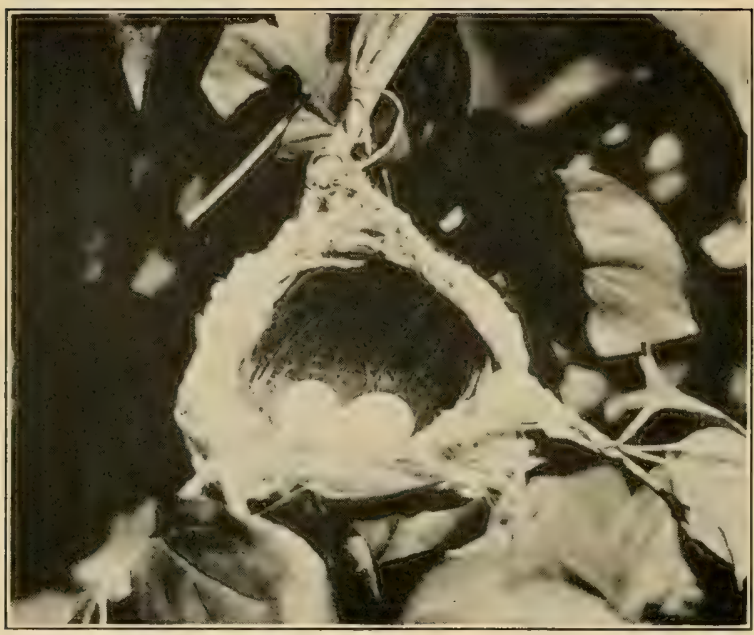

NEST OF BELL'S VIREO

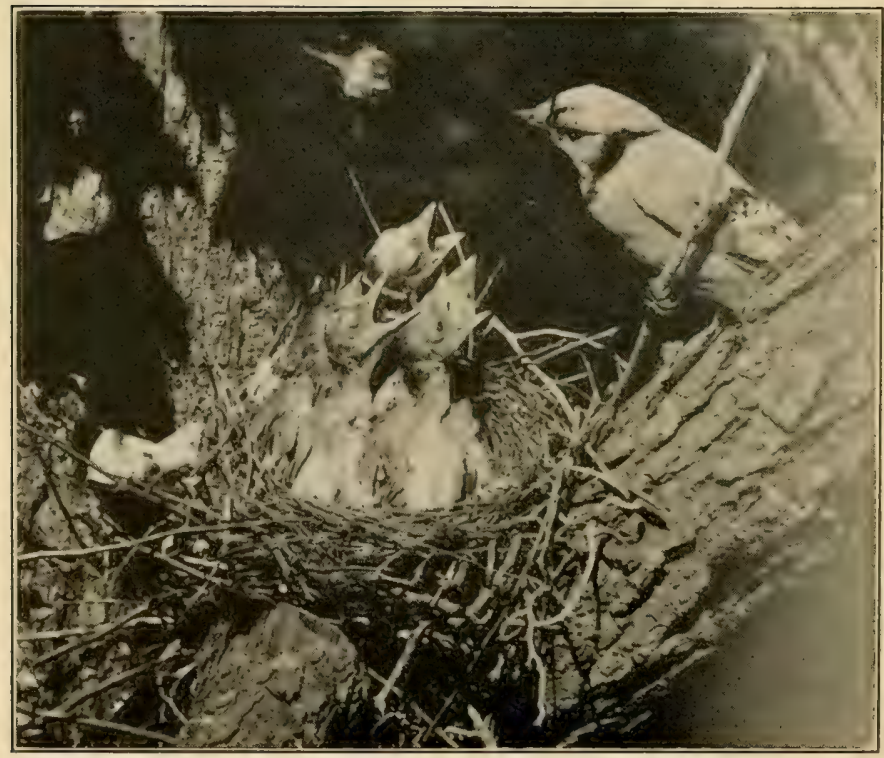

BLUE JAY'S NEST AND YOUNG 
like the Meadowlark. Breast yellow with black throat patch, the upper throat being white. One cannot ride far into the country without seeing him on fence or weed. He is always singing, but he can't sing. With strenuous repetition however, he does say, "dick dick-che, che, che che, e e e." A summer resident in the southern part of the State. Nests on the ground or in low bushes.

605. LARK Bunting (Calamospiza melanocorys.)

This splendid summer resident is found over the State but is most abundant west of the Missouri River. It is distinctly a bird of the Plains. The male is black with large white wing patches. The female is Sparrow-like in plumage, but with white tipped tail, and buff wing bars.

Nests on the ground near a sagebush or clump of weeds. As the male rises on wing he begins his song, which continues almost until he alights, and is uttered in several distinct phrases. Each song-phrase seems to coincide with a distinct flight-phase or direction. The Lark Bunting is often confused with the Bobolink.

\section{FAMILY TANGARID王. TANAGERS}

The Tanagers are not plentiful in South Dakota, but their gleaming colors and rather shy ways make them subjects of great interest. One belongs to the eastern part of the State and the other to the Black Hills region. They are summer residents.

607. Western Tanager (Piranga ludoviciana.)

But for the reddish wash on head and neck, the inexperienced observer, upon seeing this bird, would exclaim, "What a large Goldfinch!" It is about the size of an Oriole. The general color is yellow. Head and neck are washed with red, while wings, shoulders across the back, and tail are black. This exquisite bird is found from the Pacific to the Plains; the Black Hills and the wooded areas of Washabaugh county are the eastern limit of its range.

608. Scarlet Tanager (Piranga erythromelas.)

The male is like a flaming torch among the trees. Every feather on its body proper is brilliant scarlet while every feather 
on wings and tail is jet black. Female olive green on back and yellow below; wings and tail slaty brown. They are summer residents in South Dakota, but are not plentiful. Seldom is more than one pair found in any grove. The song is a rather weak imitation of the Robin's, but the male's lack of musical ability is more than compensated for by its beauty.

Tanagers have short, thick bills.

\section{FAMILY HIRUNDINID瓜. SWALLOWS}

Swallows are numerous in South Dakota, but very unohtrusive. Seldom can one look up into the sky without seeing a Swallow pass. With the exception of the Martin they are not singers, and they gather their food entirely upon the wing. They come to us late in spring, when there are insects enough to eat, and leave early in autumn before the supply is too much depleted.

\section{Purple Martin (Progne subis subis.)}

This is our largest Swallow, and the only one that sings. A common summer resident, nesting readily wherever Martin houses are erected. The house may be two or three stories high and of many rooms, for these are sociable birds. The more there are together the better they seem to like it.

\section{Cliff Swallow (Petrochelidon lunifrons lunifrons.)}

These Swallows have brought their mud-bottle nests from rocky cliffs and placed them under the eaves of barns. They are therefore sometimes called the Eares Swallow. Tail square, forchead and rump buffy. They are social birds and build in colonies.

\section{Barn Swallow (Hirundo erythrogastra.)}

Barn Swallows nest inside the barn, plastering their halfsaucers to beam or rafter. They seem quite fearless of men or animals and pass in and out close to one's head. They are easily identified by their iridescent plumage; chestnut forehead, throat and upper breast; and forked tail. 


\section{TREe Swallow (Iridoprocne bicolor.)} County).

"An abundant migrant and rare breeder" (Visher, for Clay white.

Upper parts glossy green; wings and tail darker; belly

The Tree Swallows nest in abandoned Woodpecker holes and can be encouraged to rear their young in bird houses.

615. Northern Violet-Green Swallow (Tachycineta thalassina lepida.)

A western species occasionally seen in the western part of South Dakota during the summer. One of the smallest of our Swallows. Above, glossy green; around eyes and under parts white.

616. Bank Swallow (Riparia riparia.)

This is our smallest and lightest colored Swallow, being grayish brown.

It is easily recognized by the wide, grayish brown band across the breast. Like the Cliff Swallows, they nest in colonies, tunneling their holes into banks and making a grass nest at the enlarged end.

617. Rough-winged Swallow (Stelgidopteryx serripennis.)

Very like the Bank. Swallow and with similar nesting habits, but without a band across the breast.

\section{FAMILY BOMBYCILLIDA. IVAXWINGS}

Waxwings are represented in North America by only two species and South Dakota entertains one as a summer and the other as a winter resident. They are usually secn in small flocks feeding on cedar or other wild berries.

618. Bohemian Waxiving (Bombjcilla garmula.)

An irregular winter resident, always in compact flocks of a dozen or so. Brownish gray, with plumage of smooth, velvety effect. Distinguishing marks are the crest, the black throat, the wax-wing tips, and yellow on the end of the tail. They keep well up in the trees and seldom utter a note. 


\section{Cedar Waxwing (Bombycilla cedrorum.)}

A little smaller than the Bohemian, and more uniformly brownish gray in color. A common migrant, occasionally nesting. In migration these silent birds have the habit of sitting in a row on a limb. They are always in close flocks of a dozen or so, and impress one as being very much attached to each other. In 1919 a few pairs nested in the vicinity of Vermillion. The young were full grown by August 1st.

\section{FAMILY LANIID后，SHRIKES}

The Shrikes are commonly known as Butcherbirds. They kill smaller birds and mice and hang them upon a hedge thorn or the barb of a wire fence. Flies then lay their eggs in the fresh meat, and the maggots are dainty morsels for the Butcher.

621. Northern Shrike (Lanius borealis.)

About the size of a Blue Jay; bluish gray, with black wings, tail and eye line. Margin of tail and wing spots white. The white under parts are dotted with wavy bars.

622a. White-RUMPed SHRIKE (Lanius ludoricianus excubitorides.)

A common summer resident. Similar to the Northern, but smaller, and without the wavy bars on the breast. Frequently seen on telephone wires or wire fences by the roadside. Nests in low bushes and brush heaps.

\section{FAMILY VIREONID瓜. VIREOS}

The Vireos or "Greenlets" keep well among the foliage, some of them to the high tree tops. Their colors are not conspicuous, being for the most part olive green above and whitish below, and their songs attract little attention. The nest is a neat, pendent cup, the upper edge being lashed closely around the fork of a horizontal twig. The Vireos all have the "Flycatcher bill."

624. Red-eyed Vireo (T'ircosylva olivacea.)

This bird lives for the most part in the upper third of high trees. He may be recognized by the distinct white line over the eye, a black line separating it from a gray crown. His 


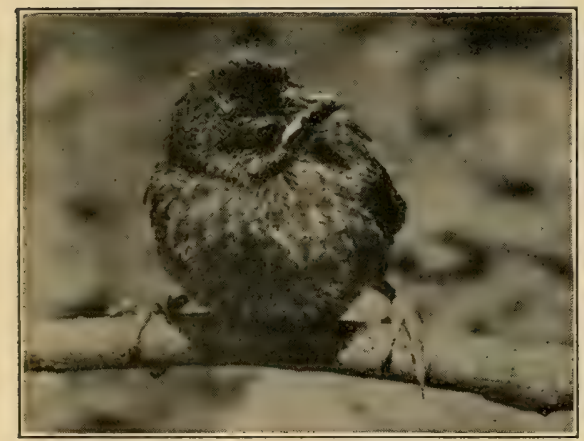

YOUNG CHEWINK

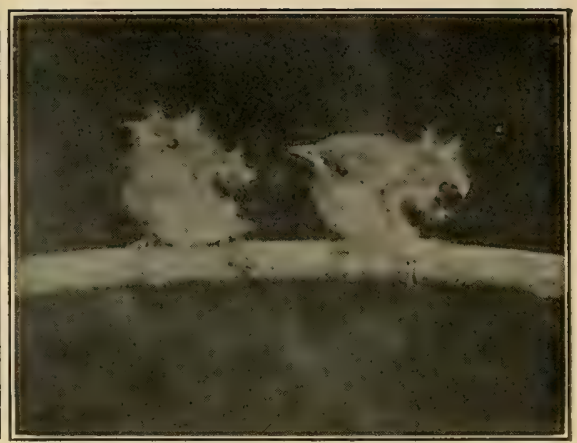

YOUNG YELLOW WARBLERS

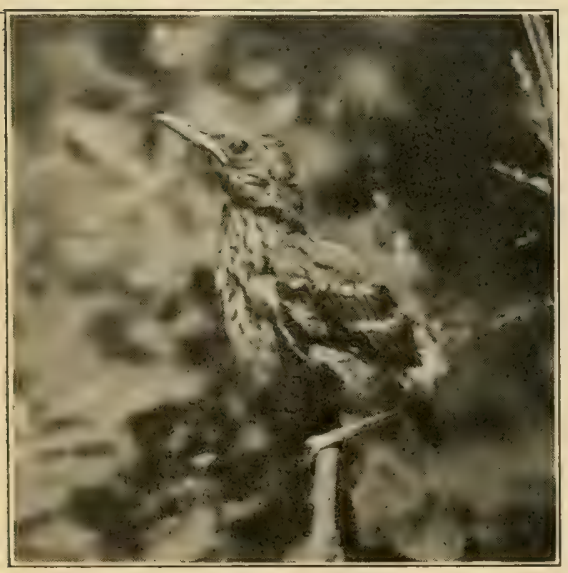

YOUNG BROWN THRASHER

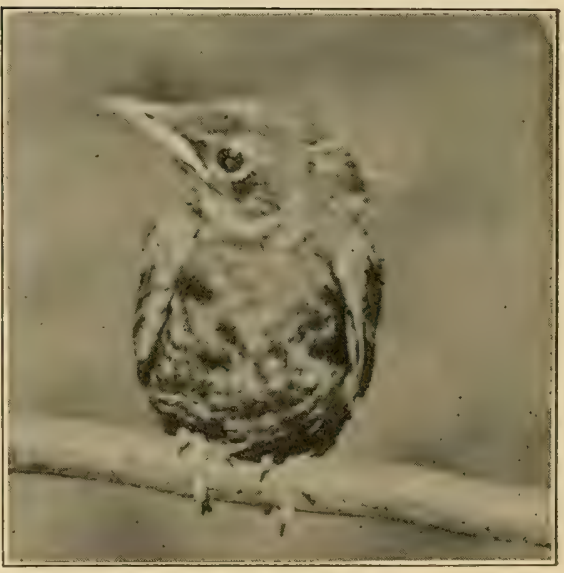

YOUNG ROBIN 
song is incessant. The rather unattractive warble has been described as "you see it-you know it-do you hear me,-do you believe it?"

627. Warbling Vireo (Vireosylva gilva gilva.)

This is our most delightful Vireo. An inhabitant of the high tree top and seldom seen, but heard almost any hour of the day. Its song is a pleasing and all but incessant warble. No day is too hot, even at the noon hour, to discourage its melody.

Similar to No. 624 but lacks the gray crown with black margin.

627a. Western Warbling Vireo (Vireosylva gilva swainsoni.)

This subspecies strays east to the western part of our State. It is similar to the preceding but slightly smaller and grayer.

629. Blue-HeAded Vireo (Lanivireo solitarius solitarius.)

"A rare spring migrant" (Visher, for Clay County). Also reported as common in migration for Iowa.

629b. Plumbeous Vireo (Lanivireo solitarius plumbeus.) kota."

Reported by Chapman as "breeding in southwestern Da-

\section{Bell's Vireo (Vireo belli belli.)}

This "Greenlet" is a lover of tall underbrush and may be found among the dogwood bushes of our river bottoms, in the stunted growth of many tree claims, or wherever tall bushes are to be found. It keeps well away from the observer, but its wavering and rather unmusical song is unmistakable.

\section{FAMILY MNIOTILTIDÆ. WARBLERS}

The Warbler family of the Western Hemisphere comprises about 140 species of small, beantifully colored hirds, most of them about the size of the Canary, Forty or fifty of the species visit the L'nited States, and most of them are migratory. The Warblers are insect eating birds, and their migrations are closely connected with this fact. They are nearly the last of the whole bird procession to come north in spring. They arrive in 
each locality about blossom time, when insects in vast numbers are emerging from the larval state to wreak depredations upon shade and fruit trees.

The great number of Warblers in migration is a constant surprise. There are days when the trees seem alive with them, and no tree escapes their helpful ministries. With few exceptions they are birds of the tree rather than of the ground. And they are birds of the wing; they literally feed on the wing and on the run; they are never still; they flit from leaf to leaf and blossom to blossom; they cling to twigs and run along branches; they search out insect eggs, feast on insect larvae and swallow mature insects indiscriminately; and they are busy in this way from daylight to dark.

Though called Warblers, they are really not songsters; they have no time to sing; they are too busy eating; they sing as they go, uttering little snatches of song between mouthfuls. These bits of song are never obtrusive, but as much a part of open woodlands, groves and orchards as atmosphere or blossoms or the humming of bees.

Warblers are birds of variegated colors, the most conspicuous being yellow and black, followed by white, blue and chestnut. These colors are usually distributed in large patches or prominent stripes on crown, throat, breast, sides, rump, tail and wings. Apart from these the general body color of the upper parts, while varying much, is apt to be bluish gray, or olive green, or a combination of these two.

\section{Black ANd White Warbler (Mniotilta varia.)}

A common migrant. Black and white striped, with a broad white stripe through the center of the black crown, and a narrower white stripe over each eye. It is sometimes called the Creeping Warbler from its habit of creeping along tree branches like the Brown Creeper.

645. Nashville Warbler (Vermivora rubricapilla rubricapilla.)

Nests in the Cave Hills Fores: Reserve of Harding County.

About four and one half inches in length. Above, olive green; below, yellow. Head gray with a brown crown-patch, but the latter is not conspicuous in the female. 
646. CRANGE-CROWNed WARBLeR (Vermivora celata celata.)

Above, olive green with concealed orange crown patch; below, dusky yellow. It is seen only in migration and might easily be mistaken for the female Summer Warbler.

\section{Tennessee Warbler (Vermivora peregrina.)}

Rare in migration over the State. Above, olive green; below, whitish. Head light slate with white line over the eyes. Plumage much like that of the Red-eyed Vireo but easily identified by its smaller size and bill.

652. Yellow Warbler (Dendroica aestiva aestiva.)

A common resident. Called also Summer Warbler. This is the only South Dakota bird that has the appearance of being wholly yellow. The yellow of the male is much less olivaceous than that of the female, while his breast is obscurely striped with broad bands of reddish brown. By many this bird is confused with the American Godfinch. Although a bird of the underbrush, in South Dakota, where there is so little underbrush, it nests freely in orchards, and even in the bushes of our door yards. It is the best known bird that discerns the danger of the Cowbird's egg, and when this egg is found in her nest, the little mother will often bury it, together with her own, by laying a new bottom and sometimes adding a second story to her nest.

655. Myrtle Warbler (Dendroica coronata.)

An abundant migrant. Bluish gray, heavily streaked and blotched with black and white; easily recognized by the yellow patches on crown, rump and sides. Tt is commonly called the Myrtle Bird.

656. Audubon's Warrler, Dendroica auduboni auduboni.)

"Seen frequently in the Black Hills; probably nests. Common spring migrant along the White River" (Sweet). It is easy to mistake this beautiful bird for the more common Myrtle Warbler. Its yellow throat patch, however, distinguishes it; and, unlike the two bars of the Myrtle Bird, the white of its wings is a solid patch. 


\section{Magnolia Warbler (Dendroica magnolia.)}

A common migrant. The casual observer must look sharply to distinguish this charming Warbler from the Myrtle Bird. The colors are the same but differently distributed. The crown lacks the yellow patch of the Myrtle Bird. The under parts are yellow, heavily streaked with black on throat and sides.

659. Chestnut-Sided Warbler (Dendroica pennsylvanica.)

A rather rare migrant, but instantly recognized by its chestnut sides, white cheeks and yellow crown.

660. BaY-BREASTED Warbler (Dendroica castanea.)

"A rare migrant" (Visher, for Clay County). Throat, sides and crown chestnut, with a black mask crossing the forehead and falling upon the cheeks.

661. Black-Poll Warbler (Dendroica striata.)

An abundant migrant. Chiefly black and white, the upper parts having a ground color of bluish gray; much like the Black and White Warblers, but the body is not so streaked; crown black; cheeks with an elongated white patch. In autumn the male has lost his black cap, both male and female having assumed the colors of their young.

662. Blackburnian Warbler (Dendroica fusca.)

"A rare spring migrant" (Visher, for Clay County). Orange and black, with a flaring white spot on the wings; crown spot, line over the eyes, eyelids, large ear patch, throat and breast flaming orange. This "flaming torch" of deep woods and big trees is one of the most exquisite birds in the Warbler family.

667. Black-throated Green Warbler (Dendroica virens.)

"An uncommon migrant" (Visher, for Clay County). Olive green, with yellow checks; throat and breast black; much white marking on the wings.

672. Palm Warbler (Dendroica palmarum palmarum.)

"A common migrant" (Visher, for Clay County). Olive brown, with dark chestnut crown; line over eye, throat and breast yellow. 



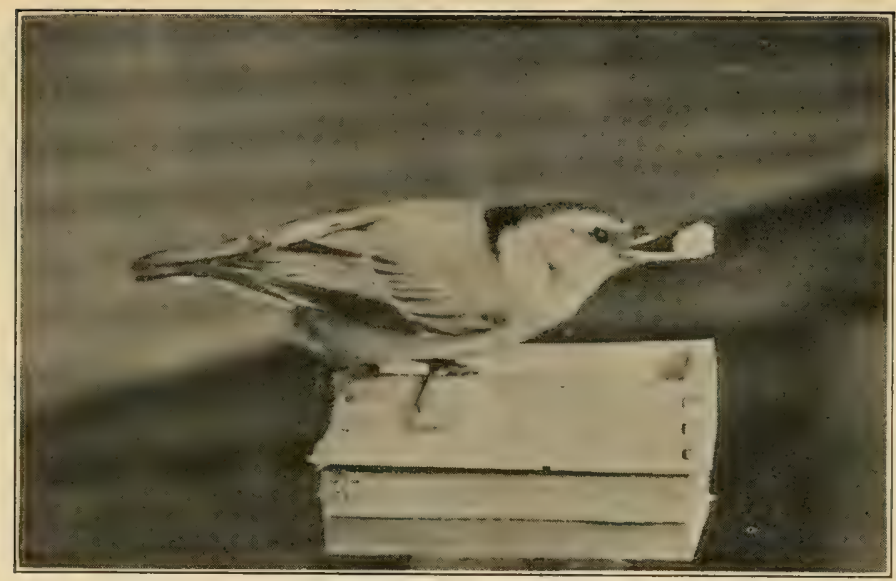

WHITE-BREASTED NUTHATCH AT FOOD BOX

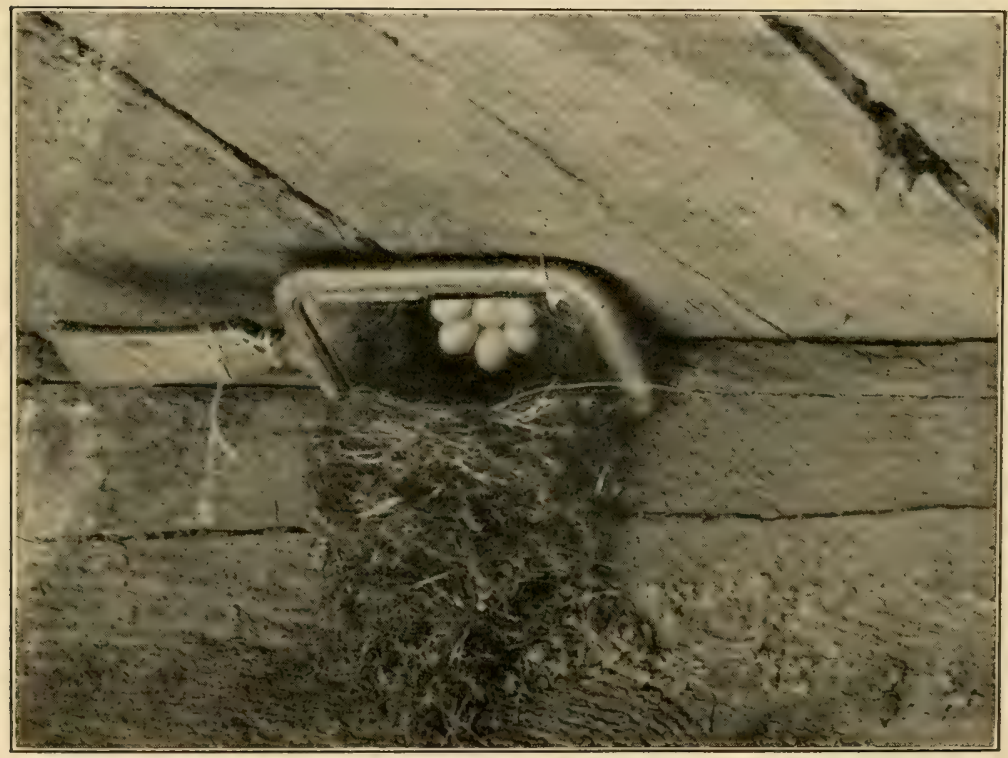

PHABE'S NEST UNDER A BRIDGE

(The Eggs are Reflected by a Mirror Placed Over the Nest.) 
674. OvEN-BIRD (Seiurus aurocapillus.)

A summer migrant and occasional resident. Somewhat larger than the English Sparrow; but very different in form. Olive green above, the white under parts heavily streaked with black on throat and sides. Two black stripes on the crown inclose a brownish, or golden patch, from which the bird has been called the "Golden-crowned Wagtail Warbler". The Uven-bird is large for a Warbler, and strictly a ground bird, though a bird of the woods. When you come upon them they walk gracefully from you like diminutive Bantam Cocks. They are most frequently seen in migration, though some nest in the State, which is in the western edge of their breeding range. They are named from their oven-like nest.

675a. Grinnell's Water-Thrush (Seiurus noveboracensis notabilis.)

A common migrant. This bird, as the name indicates, looks more like a Thrush than a Warbler. It is found along streams, and may easily be recognized from its olive colur, heavily streaked breast, yellowish line over eye, and teetering tail.

679. Mourning Warbler (Oporornis philadelphia.)

A rare migrant in eastern South Dakota. Olive green, the bluish slate of head and neck darkening from throat to lower breast, where it meets the yellow belly.

680. Macgillivray's Warbler (Oporornis tolmiei.)

"A summer resident of southwestern South Dakota" (Henshaw). Scarcely distinguishable from the Mourning Warbler but for the white eye ring above and below the eyes. Its favorite habitat is in bushes along streams and in moist places.

681a. WeStern Yellow throat (Geothlypis trichas nccidentalis.)

A summer resident. Upper parts rich olive green; under parts bright yellow. The male wears a black mask across the forehead which falls obliquely upon the checks, including the eyes. One wonders if a little bird bandit is challenging one's right to intrude in his neighborhood as curiosity brings him to the top of bush or weed. The Yellowthroat's favorite haunt is 
among underbrush or clumps of tall weeds adjacent to low or swampy ground. The nest is on or near the ground, and here most of the bird's time is spent. The song is a cheerful "witchy, witchy, witch," which, when once heard, can never be forgotten.

683. Yellow-Breasted Chat (Icteria virens virens.)

Upper parts olive green, with a clear white line over the eye reaching to the base of the bill; throat and breast bright yellow. The Chat is nearly as large as an Oriole, and so unlike all other Warblers that the ordinary observer would not put him in the Warbler family but for the insistence of the books that he belongs there. These birds love a tangle of trees, vines and bushes, such as are often found in the fringe of woods skirting the Missouri River. They love to be heard rather than seen, and when you are in their vicinity the male whistles, quacks, barks, chuckles and makes numerons other noises, seemingly to attract your attention. His love antics are like the bucking of a bronco. With drooping wings and legs, and intensified quacks and whistles, he bucks his way in aerial circles for the admiration of his mate.

685. Wilson's Warbler (Wilsonia pusilla pusilla.)

"A common migrant" (Visher, for Clay County). Olive green, with shiny black crown, and forehead; cheeks and under parts yellow.

687. REDSTART (Setophaga ruticilla.)

A common migrant and a frequent summer resident. The male is black, with salmon red on sides, wings and tail. When the tail is spread in flight the salmon patches are large and fan shaped, and are the bird's best distinguishing mark. This little "torch-bearer," as the Spaniards call it, is seen in a certain grove near Vermillion nearly every year in June and July, where it evidently nests. It is one of the choicest of the IVarbler family, extremely light and airy of wing, flitting and poising like a Hummingbird as it gathers insect food from leaf and blossom.

\section{FAMILY MOTACILLID无. PIPITS}

697. PiPit; "Titlark" (Anthus rubescens.)

This interesting bird, though not common, is found locally 
over the State. It is a slim Sparrow-like bird with a long hindtoe nail. Upper parts brownish gray; below, brownish gray, streaked with black on sides of breast. Sexes are alike in plumage but vary slightly with season to a buffy appearance. Song uttered while on the wing.

700. Sprague's Pipit; "Titlark" (Anthus spraguei.)

A common migrant in the eastern part of the State, nesting in the western part. Very similar to the American Pipit but more buffy above and below and streaked with brownish black.

A bird of the plains with feeding habits resembling those of the Horned Larks. It delivers its song while in a soaring flight. Dr. Elliott Coues says, "The song itself possesses all the qualities which have made the European Skylark famous."

\section{FAMII,Y CINCLIDE. DIPPERS}

701. Dipper (Cinclus mexicanus unicolor.)

The Dipper or Water Ouzel is a slate colored Thrush found in South Dakota which the ordinary observer would never suspect of being a Thrush. It is a bird of the mountains and of the tumbling water of rock bottomed streams. Within our State, therefore, it is found only in the Black Hills. These birds love the rocks in midstream that are partially submerged. Here they are accustomed to feed by dipping under the water with head upstream. The song resembles somewhat that of the Brown Thrasher but is sweeter and more subdued.

\section{FAMILY MIMIDE. THRASHERS, MOCKING BIRDS}

702. Sage Thrasher (Oreoscoptes montanus.)

A summer resident west of the Missouri River. Smaller than the Brown Thrasher. Brownish gray above; below, white streaked with black; outer tail feathers tipped with white.

703a. Western Mocking Bird (Mimus polyglottos leucopterus.)

South Dakota is north of the range of the Western Mockers, although they are occasionally seen in the Black Hills or along streams on the adjacent plains. These matchless songsters are ashy gray above and soiled white below, with wing 
patches and outer tail feathers white. The Western is distinguished from the Southern Mocker by a brownish tinge below and larger white wing patches. The Mocking Birds have no equal as singers, and it is hoped that by kind treatment they may become regular summer residents of our State.

\section{CATBIRD (Dumetella carolinensis.)}

This slate colored bird is familiar everywhere in South Dakota. It is named from its catlike danger note, and, like the Brown Thrasher, is a lover of thorns and thickets. It is the nearest relative of the Mocking Bird. While the Catbird is known better for its catcall than for its song, it is really a fine singer, and has been pronounced our most accurate songster by musically trained bird students. Being a mocker, its song is a medley of other birds' notes, which often deceives the unmusical bird lover. One will sometimes come upon the male in a deep thicket practicing his song in an undertone with closed eyes. The finest song one of the authors ever heard from this mocker was given from the midst of a low bush in a pouring rain.

\section{Brown Thrasher (Toxostoma rufum.)}

The Brown Thrasher is a familiar summer resident in every part of the State. It is a bird of the underbrush, the plum thicket, the brushpile, and the thistle-bestrewn pasture. Its tail is noticeably long-about as long as its rusty body. Although they are quite in keeping with the thorny places which the bird loves, its yellow eyes, skulking manner, and threatening, hissing notes, make the impression on one that the bird is unwarrantably concealing something. But the impression is wholly inconsistent with the bird's character, which is in every way excellent. Its real nature flows forth in its song, which is sung from the highest tree tops, and is a musical performance of real merit, which often continues intermittently for half an hour.

\section{FAMILY TROGLODYTIDE. WRENS}

715. Rock WREN (Salpinctes obsoletus obsoletus.)

A common summer resident in South Dakota from the 
Missouri River westward. Larger than our well known House Wren and of paler plumage. The general color is grayish mixed with black, very little of the cinnamon brown showing on the rump. It nests in the rocky bluffs of rivers and badlands.

721a. Western House Wren (Troglodytes aedon parkmani.)

A small bird about five inches long. Above, brownish gray with narrow black bars. Below, lighter.

This is the common Wren that comes familiarly about our homes, and is always active and always singing. The Wrens will build a nest in any sort of house that is made for them, and a second home will generally secure their second brood. They are exceedingly useful in destroying insects. The song of the Wren with its cheery, gurgling melody, is always welcome in the spring.

722. Winter Wren (Nannus hiemalis hiemalis.)

Probably only a summer resident. The smallest of our Wrens. Above, dark brown, irregularly barred with black and white. Below, brown; sides and belly barred with black.

724. Short-BILled Marsh Wren (Cistothorus stellaris.)

A common resident in the marshes of the eastern and southern parts of the State. Its nest, which is a hollow ball of grasses entered from the side, is lashed to the rushes. Ere the female arrives from the south the male has built several "cock nests," hoping that she will choose one of them. The House Wren shows similar habits when he carries a few twigs into several bird houses.

Slightly smaller than the House Wren and more or less streaked with white on the back; sides rusty.

725d. Prairie Marsh Wren (Telmatodytes palustris iliacus.)

A summer resident wherever sloughs or marshes abound in the State. One inch longer than No. 724. Above, streaked with black, mixed with brown and white. Below, white, washed with rusty. 


\section{FAMILY CERTHIIDÆ. CREEPERS}

\section{Brown Creeper (Certhia familiaris americana.)}

A regular winter resident. A small, slender bird slightly larger than a Wren; brown, lightly streaked with whitish. It is seen creeping up tree trunks, usually in spirals. In gathering food it goes from tree to tree, alighting on the trunk near the ground and leaving it after reaching the branches.

\section{FAMILY SITTIDE. NUTHATCHES, CHICKADEES}

Nuthatches are represented in South Dakota by two species, both winter residents. Chickadees are represented by two species, both annual residents. They are an interesting group to study in their natural habitat and take kindly to artificial feeding during the winter.

727. White-breasted Nuthatch (Sitta carolinensis carolinensis.)

Common in winter, frequently remaining all summer and nesting. Ashy gray above, white below, with a black cap extending low on the neck. The unpracticed observer must be careful not to confuse this bird with the Chickadee. Both are ashen color, but the Nuthatch is a chunky, flattish bird. His favorite position is head downward on a tree trunk, and he gathers his food going downward rather than upward.

\section{Red-breasted Nuthatch (Sitta canadensis.)}

A winter visitant, somewhat irregular in the southern part of the State. Smaller than the preceding, with a black line through the eye and reddish under parts.

\section{Tufted Titmouse (Baeolophus bicolor.)}

During the fall of $1920 \mathrm{Mr}$. R. A. Morgan of Vermillion had many opportunities of observing this interesting little bird at his feed box.

In its established range the Titmouse is a resident but probably only a straggler here. However, it may be looked for in the southern part of the State.

Slightly larger than the Chickadee, it may be distinguished from the latter by a gray crest. Above it is ashy gray, below, 


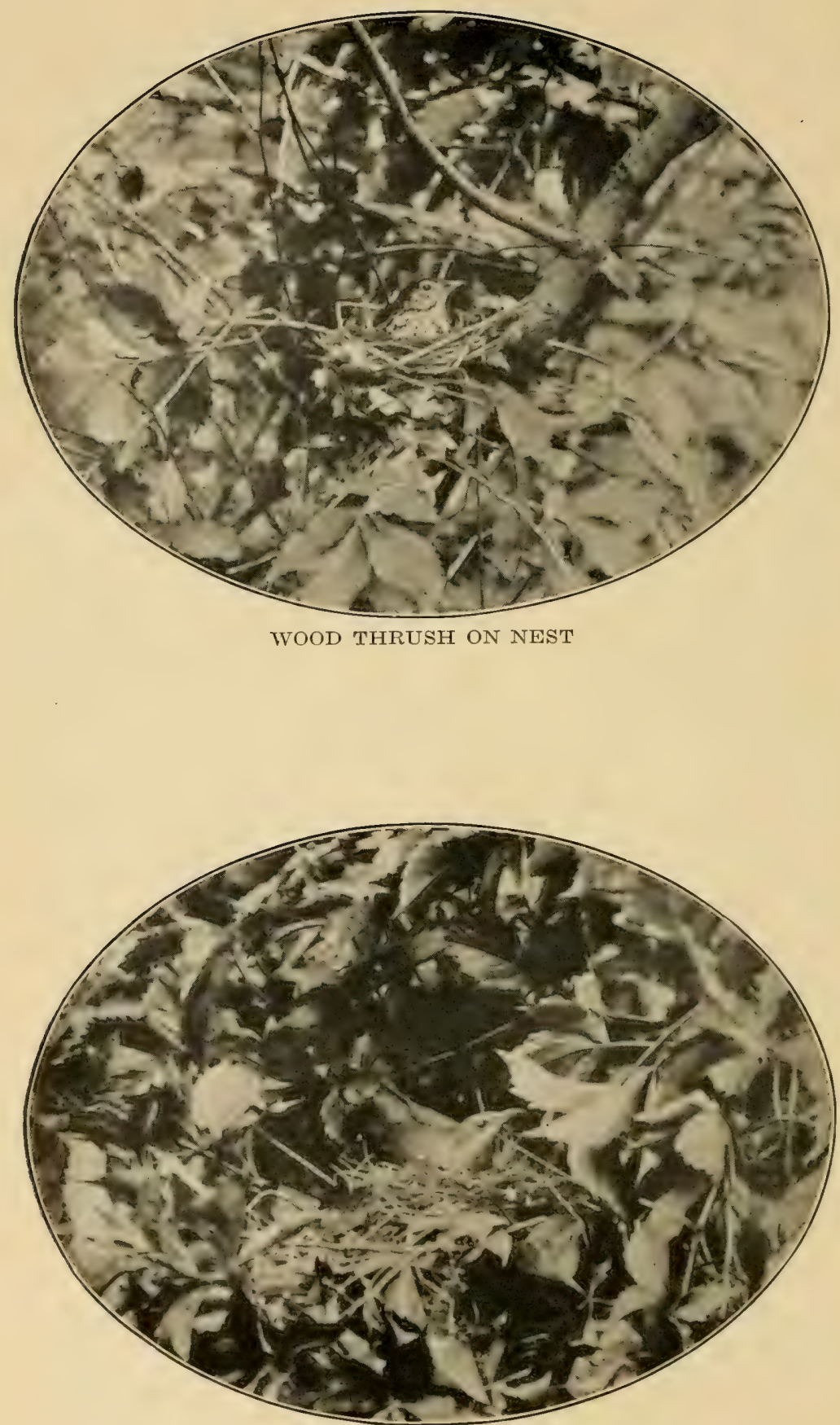

YELLOW-BILLED CUCKOO ON NEST 
whitish with brown on sides. Forehead black. Nests in old Woodpecker holes.

\section{Chickadee (Penthestes atricapillus atricapillus.)}

A permanent resident, and one of our most charming small birds. Ashen body, lighter on under parts and cheeks; black cap and throat. Nuts and suet quickly entice it to a food box in winter and an excavation made in an old tree trunk will often induce it to nest in summer. Its most common note is "chi-dee-dee-dee." On warm winter days it utters a "phoebe" note, which leads many to confuse it with a Flycatcher by that name.

735a. Long-Tailed Chickadee (Penthestes atricapillus septeritrionalis.)

A winter resident in the Black Hills and northward. Similar to the preceding but tail longer. General appearance paler and lighter.

\section{FAMILY SYLVIID压, KINGLETS}

We see the Kinglets only in migration. They are no larger than Wrens, and their greenish gray plumage attracts little attention. Both species migrate at the same time and are frequently found together. They are scarcely distinguishable to the ordinary observer, as their brilliant crown patches are nearly overlaid with other feathers. They are very active birds, flitting through trees like Warblers in search of food. Their general color is olive green.

748. Golden-Crowned Kinglet (Regulus satrapa satrapa.)

The male has crown with heart of orange. The orange is encircled by yellow, and the yellow by black. The crown of the female is yellow.

749. Ruby-Crowned Kinglet (Regulus calendula calendula.)

The size of a Wren, olive green above, lighter below. The male has a ruby patch on the crown, but it is usually overlaid with greenish feathers. 


\section{FAMILY TURDIDÆ. THRUSHES, BLUEBIRDS}

The Thrush family is well represented in South Dakota, as indeed in all parts of the United States. It is preeminently the singing family among birds; and, as though one superb gift was enough for one family, its members are clothed in modest colors.

\section{Townsend's Solitaire (Myadestes townsendi.)}

A summer resident of the Black Hills. One was taken July 24, 1911 by S. S. Visher.

Size of the Kingbird. Above, ashy brown; wings and tail darker, outer tail feathers edged with white; below, light gray.

\section{Wood Thrush (Hylocichla mustelina.)}

The Wood Thrush is not widely distributed over the State, but is a common resident in the southeastern corner. Its upper parts are bright cinnamon brown; its under parts pure white freely speckled with roundish black spots. It must not be confused with the Olive-backed Veery and Gray-cheeked Thrushes, all of which are smaller and more olivaceous. They are not readily distinguished from each other but together form a numerous group in migration. They do not nest within the State. Neither must the Wood Thrush be confused with the Brown Thrasher, which is similar in color, but has a curved bill, yellow eye ring, long tail, and skulking manner.

The Wood Thrush is a thoroughly lovable bird, with neat form, graceful movements, and frank, open manner. They come freely about our homes and often place their nests in the trees of our yards, though ordinarily preferring a wooded ravine if free from bird enemies. This Thrush is one of our best singers. Its bell-like notes, uttered with marked pauses, are heard at morning and evening and on cloudy days, the bird usually perching on some low branch as it sings. The song rivals that of the Hermit Thrush, but, unlike the Hermit, it brings its melody to our door instead of requiring us to go to the deep forest to hear it.

756. VEERY (Hylocichla fuscescens fuscescens.)

This Thrush migrates in company with the Olive-backed and Gray-cheeked Thrushes, and is not easily distinguishable 
from them by the ordinary observer, though more rufous in color. In this three-fold migrating company the Olive-backed is by far the most numerous and dominates the group to such an extent that the other two are apt to pass unobserved. The breeding range of the Wilson Thrush, as this bird is called, is north of South Dakota in our longitude.

756a. Willow Thrush (Hylocichla fuscescens salicicola.)

This Thrush is found among the lower willowy portions of the Rockies, and is named from this fact. It is quite common in migration in the eastern part of the State, and may be found nesting by the willow lined streams of the Black Hills. It is about the same size as the Gray-cheeked and Olive-backed Thrushes, but the upper parts are more russet. It is similar to the Wilson Thrush in coloration.

\section{Gray-cheeked Thrush (Hylocichla aliciae aliciae.)}

The ordinary observer will with difficulty distinguish this bird from the Olive-backed Thrush. It is about the same in size and coloration, except that its eye ring is whitish instead of buff, and its cheeks are gray instead of yellowish. It migrates through South Dakota to its northern nesting home about the same time as the Olive-backed, and few are aware that more than one species is passing.

758a. Olive-Backed Thrush (Hylocichla ustulata sicainsoni.)

This Thrush is very abundant in the southeastern part of the State in spring migrations. At Vermillion it fairly takes possession of the town, being seen for a few days in every yard. A week or more is often required for the whole procession to pass. Sometimes it is mistaken for the Wood Thrush; but it arrives earlier, is a little smaller, and decidely more olivaceous. The white breast is not pure white and luminously spotted like that of the Wood Thrush, but has an olivaceous wash, with rather obscure and more blended spots.

759b. Hermit Thrush (Hylocichla guttata pallasi.)

Seen only as stragglers in migration in the eastern part of the State, arriving about ten days earlier than the other Thrushes. It has been observed by the authors for several years 
but never certain as to its identity. On April 20,1920, a dead bird was found by Miss Bertha Nagle of Vermillion, which proved to be a Hermit Thrush. On close examination they can be easily separated from the abundant Olive-backed Thrush by the reddish brown tail and absence of any buff on breast and sides of neck. In size they are about the same.

\section{RoвIN (Planesticus migratorius migratorius.)}

Few people think of the Robin as a Thrush. He is just "the Robin" to us-one of the common people, a good neighbor, a dependable friend, a thoroughly substantial bird citizen.

The Robin, however, is the typical Thrush, the most highly developed of them all. Everything about this exceedingly satisfactory bird might well be characterized by the one word, substantial--its colors, its song, its nest, its young, its friendship, its prowess. Robins are found all over our State in summer, and in the southeastern part loose flocks not infrequently remain all winter. Indeed in our coldest winters flocks of twenty or more have been seen on the University campus and in the wooded ravines at Vermillion.

The Robin is the first bird in the migrating procession to arrive from the south. Even after his lusty song has been heard, snowstorms are not infrequent. At such times half a dozen may often be seen in the top of a maple feeding on the swelling buds.

761a. Western Robin (Planesticus migratorius propinquus.)

A summer resident in the Black Hills and Harding County. Similar to the preceding but there is no white on the tail feathers. Feeding and nesting habits the same.

766. BlueBIRd (Sialia sialis sialis.)

The Bluebird, sometimes called Wilson's Bluebird, is a close companion of the Robin in its spring arrival in the north and, like the Robin, occasionally winters in South Dakota.

Length seven inches. Male: above, bright blue; throat and breast reddish brown; lower belly white; female : paler, both above and below. 
768. Mountain Bluebird (Sialia currucoides.)

This exquisite bird, sometimes called Arctic or Rocky Mountain Bluebird, belongs to the mountains and the intermountain plateaus. It is found within the State, therefore, only in the Black Hills and in the badland areas. It lacks the chestnut breast of its eastern cousin and is of a lighter blue. On seeing this bird for the first time one goes into transports of delight. It is like a winged bit of sky from the snow crowned peaks where the sky is purest. And, as though to accentuate its beauty, it has a delightful habit of poising like a Hummingbird on wing while watching for insects in the grass. 



\section{BIBLIOGRAPHY}




\section{BIBLIOGRAPHY}

The following books, bulletins, pamphlets, reprints and magazine articles comprise those that the reader will find most helpful in further study of South Dakota birds. The authors have found C. A. Reed's "Bird Guide, Land Birds East of the Rockies" a pocket manual helpful for identification in the field; Dr. Elliott Coues' "Key to North American Birds" indispensable for detailed description; Mr. Frank M. Chapman's "Color Key to North American Birds" helpful in comparative analysis, and Farmers' Bulletin 513, entitled "Fifty Common Birds of Farm and Orchard," informing as to food of birds.

Audubon, John J.,-The Birds of North America.

Agersborg, C. S.-List of Birds of Southeastern South Dakota. The Auk, 1885.

Anderson, Rudolph M.,-The Birds of Iowa. Davenport Academy of Science, 1907, Davenport, Iowa.

Bailey, Bert Heald-The Raptorial Birds of Iowa. 1918. Iowa Geol. Surv.

Beal, F. E. L.,--Some Common Birds Useful to the Farmer. U. S. Bur. of Biol. Survey, Farmers' Bull. 630, 1915, Washington, D. C.

Beal, F. E. L. and W. L. McAtee-Food of Some Well Known Birds of Forest, Farm and Garden. U. S. Bur, of Biol. Survey, Farmers' Bulletin 506, 1915, Washington, D. C.

-Fifty Common Birds of Farm and Orchard. U. S. Bur. of Biol. Survey, Farmers' Bulletin 513, 1913, Washington, D. C.

Coues, Elliott-Key to North American Birds. 1903, two vols.

Chapman, Frank M.-Color Key to North American Birds. D. Appleton and Co., New York.

- The Travels of Birds, D. Appleton and Co.

-A Bird Book for Teachers. D. Appleton and Co.

- The Warblers of North America. D. Appleton and Co. 
- Handbook of Birds of Eastern North America. D. Appleton and Co.

-Bird Life. D. Appleton and Co.

Grinell, G. B.--List of Birds Collected as Zoologist With Custer Expedition, 1874.

Graves, B. H. and Ernest P. Walker-Birds of Wyoming. University of Wyoming, 1913.

Hayden, F. V.-List of Birds Collected in Territory That Is Now South Dakota in 1857-1860. U. S. Geological Survey. Washington, D. C.

Holmes, Charles E.-Birds of the West. Hammond and Stephens Co., 1907, Fremont, Neb.

Jones, Sheridan R.-List of Birds of Rosebud Indian Reservation. S. D. Geol. and Nat. Hist. Survey, Bull. No. 4, 1908, pp. 139-142, Vermillion, S. D.

McAttee, W. L. and F. E. L. Beal-Some Common Game, Aquatic and Rapacious Birds in Relation to Man. U. S. Bur. of Biol. Survey, Farmers' Bulletin 497, 1916, Washington, D. C.

McChesney, C. E.-Birds of the Coteau des Prairies. Forest and Stream, 1871.

Roberts, Thos. S.-Winter Birds of Minnesota. Geol. and

Nat. Hist. Survey Minn., 1916, Minneapolis; Minn.

-Water Birds of Minnesota. State Game and Fish Com., Minneapolis, Minn.

Reagan, Albert B.-List of Birds Seen on the Rosebud Indian Reservation. S. D. Geol. and Nat. Hist. Survey, Bulletin No. 4, 1908, pp. 154-164, Vermillion, S. D.

Reed Charles A.-Bird Guide, Land Birds East of the Rockies. Doubleday, Page and Co., New York.

Stephens, T. C.-Notes on the Birds of South Dakota, With a Preliminary List for Union County. Proc. Iowa Academy of Science, XXV, 1918.

- Red Phalarope in South Dakota. Wilson Bulletin, XXVIII, 1916, p. 92. 
Tullsen, H.-My Avian Visitors. The Condor, May-June, 1911, p. 89.

Visher, Stephen S.-List of the Birds of Western South Dakota. The Auk, April, 1909, p. 144.

-An Annotated List of the Birds of Sanborn Co. South Dakota. The Auk, Oct., 1913.

- List of Birds of the Pine Ridge Indian Reservation. S. D. Geol. and Nat. Hist. Survey, Bulletin No. 5, pp. 109-121, 1912, Vermillion, S. D.

- List of Birds of Harding County. S.

D. Geol. and Nat. Hist. Survey, Bull. No. 6, pp. 68-87, 1914, Vermillion, S. D.

- List of the Birds of Clay County, Southeastern South Dakota. The Wilson Bull. No. 91, June 1915.

- South Dakota Geological and Natural History Survey, Bulletin No. 8, 1918, pp. 68-108, Vermillion, S. D. 






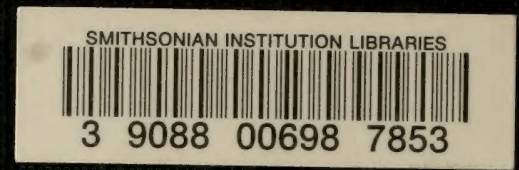

